\title{
Intra-articular corticosteroid for knee osteoarthritis (Review)
}

Jüni P, Hari R, Rutjes AWS, Fischer R, Silletta MG, Reichenbach S, da Costa BR

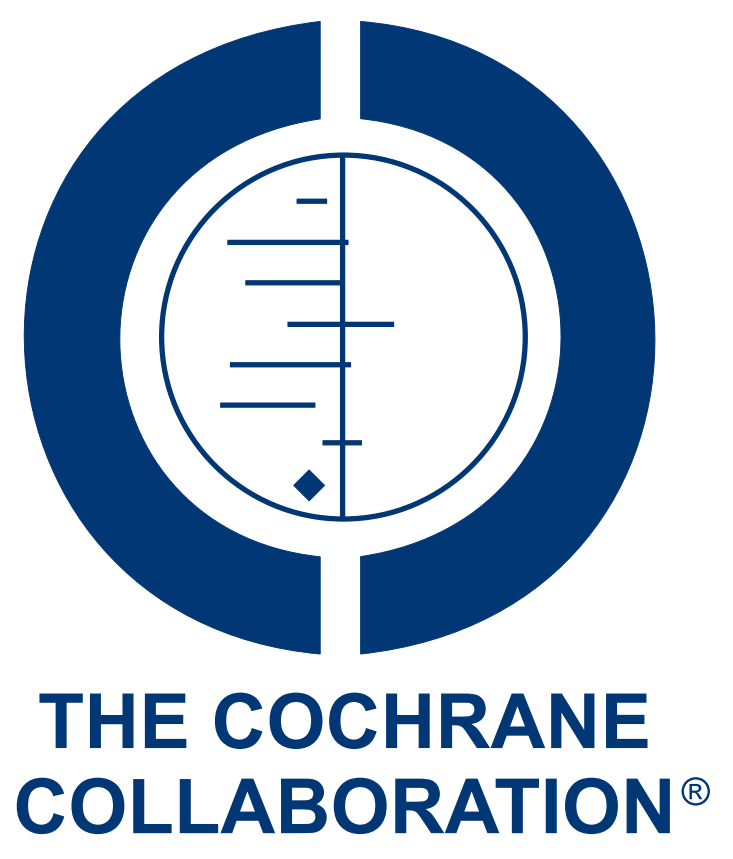

This is a reprint of a Cochrane review, prepared and maintained by The Cochrane Collaboration and published in The Cochrane Library 2015, Issue 10

http://www.thecochranelibrary.com

\section{WILEY}

Intra-articular corticosteroid for knee osteoarthritis (Review)

Copyright @ 2015 The Cochrane Collaboration. Published by John Wiley \& Sons, Ltd. 
TABLE OF CONTENTS

HEADER

ABSTRACT

PLAIN LANGUAGE SUMMARY . . . . . . . . . . . . . . . . . . . . . . . . . . . . . . . . . . 2

SUMMARY OF FINDINGS FOR THE MAIN COMPARISON . . . . . . . . . . . . . . . . . . . . . . . 5

BACKGROUND . . . . . . . . . . . . . . . . . . . . . . . . . . . . . . . . . . . . 7

OBJECTIVES . . . . . . . . . . . . . . . . . . . . . . . . . . . . . . . . . . . . . . . . . . . . .

METHODS . . . . . . . . . . . . . . . . . . . . . . . . . . . . . . . . . . . . . . . . .

RESULTS . . . . . . . . . . . . . . . . . . . . . . . . . . . . . . . . . . . . . . 10

Figure 1. . . . . . . . . . . . . . . . . . . . . . . . . . . . . . . . . . . . . . 11

Figure 2. . . . . . . . . . . . . . . . . . . . . . . . . . . . . . . . . . . . . . 13

Figure 3. . . . . . . . . . . . . . . . . . . . . . . . . . . . . . . . . . . . . . 14

Figure $4 . \quad$. . . . . . . . . . . . . . . . . . . . . . . . . . . . . . . . . . . . . 15

Figure 5. . . . . . . . . . . . . . . . . . . . . . . . . . . . . . . . . . . . . . 16

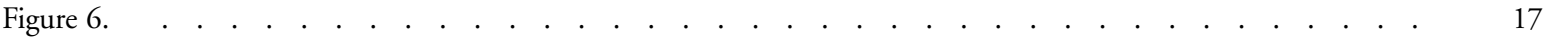

Figure 7. . . . . . . . . . . . . . . . . . . . . . . . . . . . . . . . . . 18

Figure 8. . . . . . . . . . . . . . . . . . . . . . . . . . . . . . . . . . . . 19

Figure 9. . . . . . . . . . . . . . . . . . . . . . . . . . . . . . . . . . . . 20

Figure 10. . . . . . . . . . . . . . . . . . . . . . . . . . . . . . . . . . . . . . 20

Figure 11. . . . . . . . . . . . . . . . . . . . . . . . . . . . . . . . . . . . . . 20

Figure 12. . . . . . . . . . . . . . . . . . . . . . . . . . . . . . . . . . . . . . 21

Figure 13. . . . . . . . . . . . . . . . . . . . . . . . . . . . . . . . . . . . . . 21

DISCUSSION . . . . . . . . . . . . . . . . . . . . . . . . . . . . . . . . . . . . 22

AUTHORS' CONCLUSIONS . . . . . . . . . . . . . . . . . . . . . . . . . . . . . . . . . . . . . . .

ACKNOWLEDGEMENTS . . . . . . . . . . . . . . . . . . . . . . . . . . . . . . . . . . . . . . . . . .

REFERENCES . . . . . . . . . . . . . . . . . . . . . . . . . . . . . . . . . . . . . . . . . . . . .

CHARACTERISTICS OF STUDIES . . . . . . . . . . . . . . . . . . . . . . . . . . . . . . . . . . . . . . . . .

DATA AND ANALYSES . . . . . . . . . . . . . . . . . . . . . . . . . . . . . . . . . . . . . . . . . . . . . . . .

Analysis 1.1. Comparison 1 Pain, Outcome 1 Pain - Main. . . . . . . . . . . . . . . . . . . . . 72

Analysis 1.2. Comparison 1 Pain, Outcome 2 Pain - Timepoints. . . . . . . . . . . . . . . . . . . . . . . . 73

Analysis 2.1. Comparison 2 Function, Outcome 1 Function - Main. . . . . . . . . . . . . . . . . . . 76

Analysis 2.2. Comparison 2 Function, Outcome 2 Function - Timepoints. . . . . . . . . . . . . . . . . . . . 77

Analysis 3.1. Comparison 3 Quality of life, Outcome 1 Quality of life - Main. . . . . . . . . . . . . . . . . . 79

Analysis 4.1. Comparison 4 Number of participants experiencing any adverse event, Outcome 1 Number of participants experiencing any adverse event - Main.

Analysis 5.1. Comparison 5 Number of participants who withdraw because of adverse events, Outcome 1 Number of participants who with draw because of adverse events -Main.

Analysis 6.1. Comparison 6 Number of participants experiencing any serious adverse event, Outcome 1 Number of participants experiencing any serious adverse event - Main. . . . . . . . . . . . . . . . . . . 82

Analysis 7.1. Comparison 7 Joint space narrowing, Outcome 1 Joint space narrowing - Main. . . . . . . . . . . $\quad . \quad$. 83

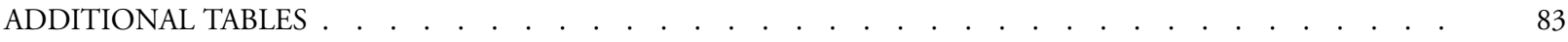

APPENDICES . . . . . . . . . . . . . . . . . . . . . . . . . . . . . . . . . . . . . . . . . . . . . . . . 8

WHAT'S NEW . . . . . . . . . . . . . . . . . . . . . . . . . . . . . . . . . . . . . . . . . . . .

HISTORY . . . . . . . . . . . . . . . . . . . . . . . . . . . . . . . . . . . . . . . . 96

CONTRIBUTIONS OF AUTHORS . . . . . . . . . . . . . . . . . . . . . . . . . . . . . . . . . . . . . . . . . . . . 96

DECLARATIONS OF INTEREST . . . . . . . . . . . . . . . . . . . . . . . . . . . . . . . . . . . . . . . . . . . . . 96

SOURCES OF SUPPORT . . . . . . . . . . . . . . . . . . . . . . . . . . . . . . . . . . . . . . . . . . . . . . .

DIFFERENCES BETWEEN PROTOCOL AND REVIEW . . . . . . . . . . . . . . . . . . . . . . . . . . . . 97

INDEX TERMS . . . . . . . . . . . . . . . . . . . . . . . . . . . . . . . . . . . . . . . . . . . . . . . . . . . 97

Intra-articular corticosteroid for knee osteoarthritis (Review)

Copyright () 2015 The Cochrane Collaboration. Published by John Wiley \& Sons, Ltd. 


\title{
[Intervention Review]
}

\section{Intra-articular corticosteroid for knee osteoarthritis}

\author{
Peter Jüni ${ }^{1}$, Roman Hari ${ }^{1}$, Anne WS Rutjes ${ }^{2,3}$, Roland Fischer ${ }^{4}$, Maria G Silletta ${ }^{2}$, Stephan Reichenbach ${ }^{5}$, Bruno R da Costa ${ }^{1}$ \\ ${ }^{1}$ Institute of Primary Health Care (BIHAM), University of Bern, Bern, Switzerland. ${ }^{2}$ Centre for Systematic Reviews, Fondazione \\ “Università G. D’Annunzio", Chieti, Italy. ${ }^{3}$ Institute of Social and Preventive Medicine (ISPM), University of Bern, Bern, Switzerland. \\ ${ }^{4}$ Department of General Internal Medicine, Inselspital Bern, Bern, Switzerland. ${ }^{5}$ Department for Rheumatology, Clinical Immunology, \\ and Allergology, University Hospital, Bern, Switzerland
}

Contact address: Bruno R da Costa, Institute of Primary Health Care (BIHAM), University of Bern, Gesellschaftsstrasse 49, Bern, 3012, Switzerland. bruno.dacosta@biham.unibe.ch.

Editorial group: Cochrane Musculoskeletal Group.

Publication status and date: Edited (no change to conclusions), published in Issue 11, 2015.

Review content assessed as up-to-date: 3 February 2015.

Citation: Jüni P, Hari R, Rutjes AWS, Fischer R, Silletta MG, Reichenbach S, da Costa BR. Intra-articular corticosteroid for knee osteoarthritis. Cochrane Database of Systematic Reviews 2015, Issue 10. Art. No.: CD005328. DOI: 10.1002/14651858.CD005328.pub3.

Copyright (C) 2015 The Cochrane Collaboration. Published by John Wiley \& Sons, Ltd.

\begin{abstract}
A B S T R A C T
Background

Knee osteoarthritis is a leading cause of chronic pain, disability, and decreased quality of life. Despite the long-standing use of intraarticular corticosteroids, there is an ongoing debate about their benefits and safety. This is an update of a Cochrane review first published in 2005 .
\end{abstract}

\section{Objectives}

To determine the benefits and harms of intra-articular corticosteroids compared with sham or no intervention in people with knee osteoarthritis in terms of pain, physical function, quality of life, and safety.

\section{Search methods}

We searched the Cochrane Central Register of Controlled Trials (CENTRAL), MEDLINE, and EMBASE (from inception to 3 February 2015), checked trial registers, conference proceedings, reference lists, and contacted authors.

\section{Selection criteria}

We included randomised or quasi-randomised controlled trials that compared intra-articular corticosteroids with sham injection or no treatment in people with knee osteoarthritis. We applied no language restrictions.

\section{Data collection and analysis}

We calculated standardised mean differences (SMDs) and 95\% confidence intervals (CI) for pain, function, quality of life, joint space narrowing, and risk ratios (RRs) for safety outcomes. We combined trials using an inverse-variance random-effects meta-analysis.

\section{Main results}

We identified 27 trials (13 new studies) with 1767 participants in this update. We graded the quality of the evidence as 'low' for all outcomes because treatment effect estimates were inconsistent with great variation across trials, pooled estimates were imprecise and did not rule out relevant or irrelevant clinical effects, and because most trials had a high or unclear risk of bias. Intra-articular corticosteroids appeared to be more beneficial in pain reduction than control interventions (SMD -0.40, 95\% CI - 0.58 to - 0.22 ), which corresponds to a difference in pain scores of $1.0 \mathrm{~cm}$ on a $10-\mathrm{cm}$ visual analogue scale between corticosteroids and sham injection and translates

Intra-articular corticosteroid for knee osteoarthritis (Review)

Copyright $\odot 2015$ The Cochrane Collaboration. Published by John Wiley \& Sons, Ltd. 
into a number needed to treat for an additional beneficial outcome (NNTB) of 8 (95\% CI 6 to 13 ). An $\mathrm{I}^{2}$ statistic of $68 \%$ indicated considerable between-trial heterogeneity. A visual inspection of the funnel plot suggested some asymmetry (asymmetry coefficient $1.21,95 \% \mathrm{CI}-3.58$ to 1.17 ). When stratifying results according to length of follow-up, benefits were moderate at 1 to 2 weeks after end of treatment (SMD $-0.48,95 \% \mathrm{CI}-0.70$ to -0.27 ), small to moderate at 4 to 6 weeks (SMD $-0.41,95 \%$ CI -0.61 to -0.21 ), small at 13 weeks (SMD -0.22, 95\% CI -0.44 to 0.00), and no evidence of an effect at 26 weeks (SMD -0.07, 95\% CI -0.25 to 0.11). An $\mathrm{I}^{2}$ statistic of $\geq 63 \%$ indicated a moderate to large degree of between-trial heterogeneity up to 13 weeks after end of treatment $(\mathrm{P}$ for heterogeneity $\leq 0.001)$, and an $\mathrm{I}^{2}$ of $0 \%$ indicated low heterogeneity at 26 weeks $(\mathrm{P}=0.43)$. There was evidence of lower treatment effects in trials that randomised on average at least 50 participants per group $(\mathrm{P}=0.05)$ or at least 100 participants per group $(\mathrm{P}=0.013)$, in trials that used concomittant viscosupplementation $(\mathrm{P}=0.08)$, and in trials that used concomitant joint lavage $(\mathrm{P} \leq 0.001)$.

Corticosteroids appeared to be more effective in function improvement than control interventions (SMD - 0.33 , 95\% CI -0.56 to 0.09), which corresponds to a difference in functions scores of -0.7 units on standardised Western Ontario and McMaster Universities Arthritis Index (WOMAC) disability scale ranging from 0 to 10 and translates into a NNTB of 10 (95\% CI 7 to 33). An $\mathrm{I}^{2}$ statistic of $69 \%$ indicated a moderate to large degree of between-trial heterogeneity. A visual inspection of the funnel plot suggested asymmetry (asymmetry coefficient $-4.07,95 \%$ CI -8.08 to -0.05 ). When stratifying results according to length of follow-up, benefits were small to moderate at 1 to 2 weeks after end of treatment (SMD -0.43, 95\% CI - 0.72 to -0.14 ), small to moderate at 4 to 6 weeks (SMD -0.36, 95\% CI - 0.63 to -0.09), and no evidence of an effect at 13 weeks (SMD -0.13, 95\% CI - 0.37 to 0.10 ) or at 26 weeks (SMD $0.06,95 \%$ CI -0.16 to 0.28$)$. An $\mathrm{I}^{2}$ statistic of $\geq 62 \%$ indicated a moderate to large degree of between-trial heterogeneity up to 13 weeks after end of treatment ( $\mathrm{P}$ for heterogeneity $\leq 0.004)$, and an $\mathrm{I}^{2}$ of $0 \%$ indicated low heterogeneity at 26 weeks $(\mathrm{P}=0.52)$. We found evidence of lower treatment effects in trials that randomised on average at least 50 participants per group $(\mathrm{P}=0.023)$, in unpublished trials $(\mathrm{P}=$ 0.023), in trials that used non-intervention controls $(\mathrm{P}=0.031)$, and in trials that used concomitant viscosupplementation $(\mathrm{P}=0.06)$.

Participants on corticosteroids were $11 \%$ less likely to experience adverse events, but confidence intervals included the null effect (RR $0.89,95 \%$ CI 0.64 to $1.23, \mathrm{I}^{2}=0 \%$ ). Participants on corticosteroids were $67 \%$ less likely to withdraw because of adverse events, but confidence intervals were wide and included the null effect (RR $0.33,95 \%$ CI 0.05 to $2.07, \mathrm{I}^{2}=0 \%$ ). Participants on corticosteroids were $27 \%$ less likely to experience any serious adverse event, but confidence intervals were wide and included the null effect (RR 0.63 , $95 \%$ CI 0.15 to $\left.2.67, \mathrm{I}^{2}=0 \%\right)$.

We found no evidence of an effect of corticosteroids on quality of life compared to control (SMD $-0.01,95 \%$ CI -0.30 to $0.28, \mathrm{I}^{2}=$ $0 \%)$. There was also no evidence of an effect of corticosteroids on joint space narrowing compared to control interventions (SMD $0.02,95 \%$ CI -0.49 to 0.46$)$.

\section{Authors' conclusions}

Whether there are clinically important benefits of intra-articular corticosteroids after one to six weeks remains unclear in view of the overall quality of the evidence, considerable heterogeneity between trials, and evidence of small-study effects. A single trial included in this review described adequate measures to minimise biases and did not find any benefit of intra-articular corticosteroids.

In this update of the systematic review and meta-analysis, we found most of the identified trials that compared intra-articular corticosteroids with sham or non-intervention control small and hampered by low methodological quality. An analysis of multiple time points suggested that effects decrease over time, and our analysis provided no evidence that an effect remains six months after a corticosteroid injection.

\section{PLAIN LANGUAGE SUMMARY}

\section{Joint corticosteroid injection for knee osteoarthritis}

\section{Review question}

We searched the literature until 3 February 2015 for studies of the effects on pain, function, quality of life, and safety of intra-articular (injected into the joint) corticosteroids compared with sham injection or no treatment in people with knee osteoarthritis.

\section{Background}

Osteoarthritis is a disease associated with a breakdown of cartilage of the joints, such as the knee. When the joint loses cartilage, the body responds by growing bone abnormally, which can result in the bone becoming misshapen and the joint painful and unstable. This can affect physical function and the ability to use the joint.

Intra-articular corticosteroid for knee osteoarthritis (Review)

Copyright () 2015 The Cochrane Collaboration. Published by John Wiley \& Sons, Ltd. 
Although osteoarthritis is generally thought to be of degenerative rather than inflammatory origin, an inflammatory component may be present at times. Intra-articular corticosteroids are potent anti-inflammatory agents injected inside the knee joint.

\section{Study characteristics}

After searching for all relevant studies to 3 February 2015, we found 27 randomised controlled trials with a total of 1767 participants, of a duration ranging from two weeks to one year.

\section{Key results}

Pain

- People who received intra-articular corticosteroids rated improvement in their pain to be about 3 on a scale of 0 (no pain) to 10 (extreme pain) after 1 month.

- People who received a placebo rated improvement in their pain to be about 2 on a scale of 0 (no pain) to 10 (extreme pain) after 1 month.

Another way of saying this is:

- 44 people out of 100 who receive intra-articular corticosteroids respond to treatment (44\%).

- 31 people out of 100 who receive a placebo respond to treatment (31\%).

- 13 more people respond to treatment with intra-articular corticosteroids than with placebo (difference of 13\%).

Note that these numbers may considerably overestimate the true benefit due to the low quality of the evidence.

Physical function

- People who received intra-articular corticosteroids rated improvement in their physical function to be about 2 on a scale of 0 (no disability) to 10 (extreme disability) after 1 month.

- People who received a placebo rated improvement in their physical function to be about 1 on a scale of 0 (no disability) to 10 (extreme disability) after 1 month.

Another way of saying this is:

- 36 people out of 100 who received intra-articular corticosteroids respond to treatment (36\%).

- 26 people out of 100 who received a placebo respond to treatment (26\%).

- 10 more people respond to treatment with intra-articular corticosteroids than with placebo (difference of $10 \%$ ).

Note that these numbers may considerably overestimate the true benefit due to the low quality of the evidence.

Side effects

- 13 people out of 100 who used intra-articular corticosteroids experienced side effects (13\%).

- 15 people out of 100 who used a placebo experienced side effects (15\%).

- 2 more people experienced side effects with placebo than with intra-articular corticosteroids (difference of $2 \%$ ).

Dropouts because of side effects

- 6 people out of 1000 who used intra-articular corticosteroids dropped out because of side effects (0.6\%).

- 17 people out of 1000 who used a placebo dropped out because of side effects (1.7\%).

- 11 more people dropped out because of side effects with placebo than with intra-articular corticosteroids (difference of $1.1 \%$ ).

Side effects resulting in hospitalisation, persistent disability, or death

- 3 people out of 1000 who used intra-articular corticosteroids experienced side effects resulting in hospitalisation, persistent disability, or death $(0.3 \%)$.

- 4 people out of 1000 who used a placebo experienced side effects resulting in hospitalisation, persistent disability, or death(0.4\%).

Intra-articular corticosteroid for knee osteoarthritis (Review)

Copyright $\odot 2015$ The Cochrane Collaboration. Published by John Wiley \& Sons, Ltd. 
- 1 more person experienced side effects resulting in hospitalisation, persistent disability, or death with placebo than with intra-articular corticosteroids (difference of $0.1 \%$ ).

Based on the evidence, intra-articular corticosteroids may cause a moderate improvement in pain and a small improvement in physical function, but the quality of the evidence is low and results are inconclusive. Intra-articular corticosteroids appear to cause as many side effects as a placebo. However, we do not have precise and reliable information about side effects.

\section{Quality of evidence}

We graded the quality of the evidence as low for all of our findings, which means that we have little confidence in these results. This was because results were generally highly discordant across studies and mainly based on small studies of low quality. 


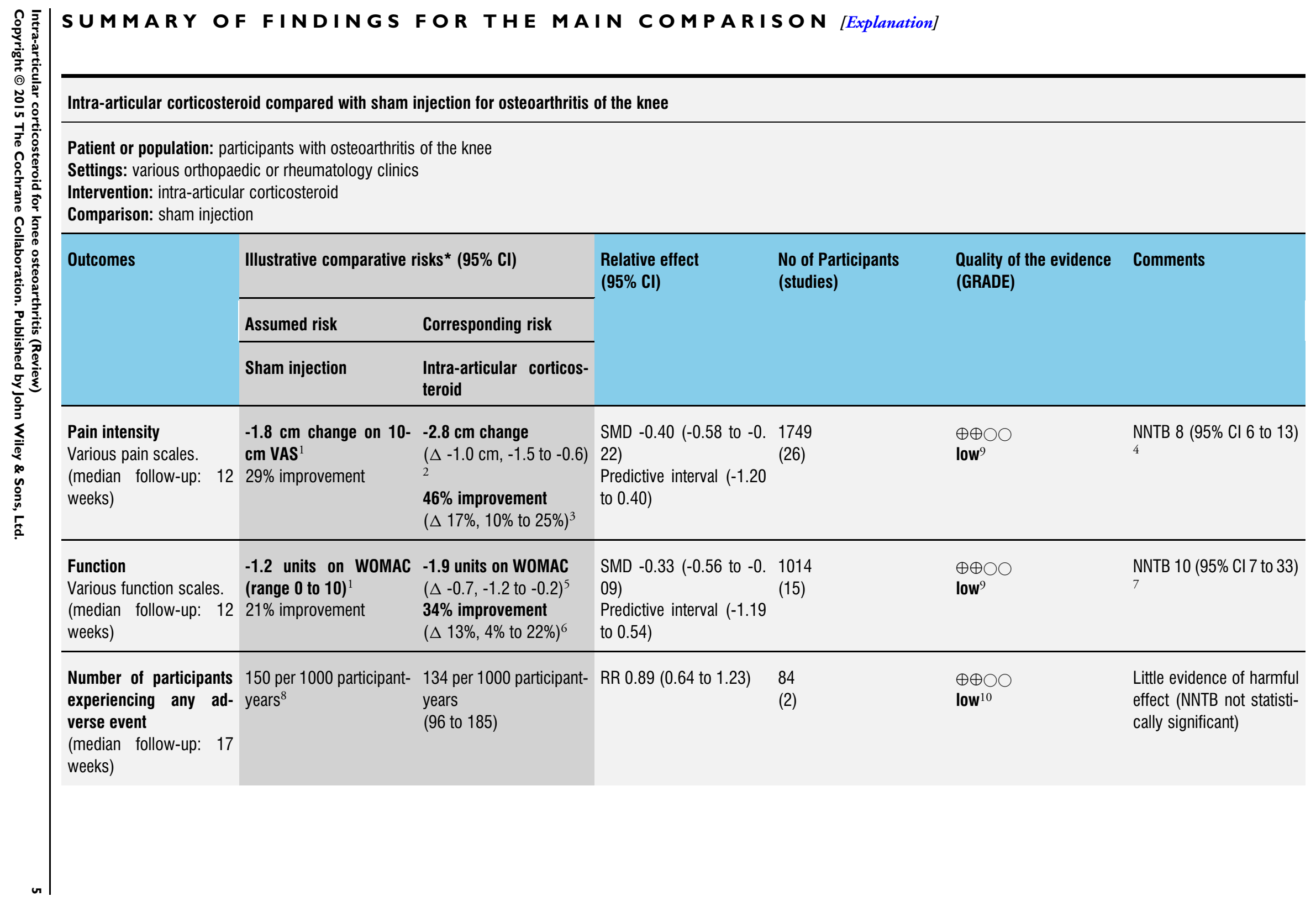




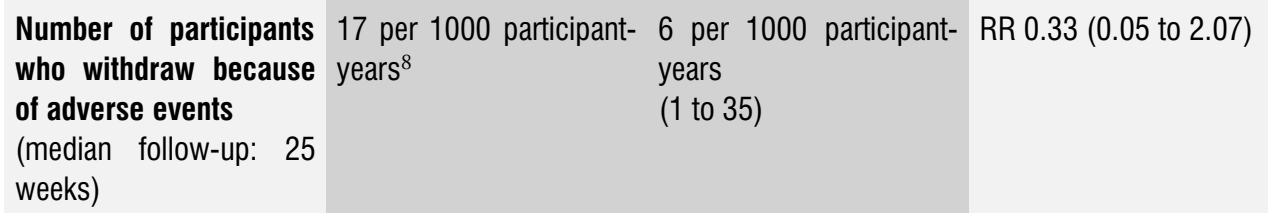

(median follow-up: 25

weeks)

204

Number of participants 4 per 1000 participant- 3 per 1000 participant- RR 0.63 (0.15 to 2.67)

experiencing any seri- years $^{8} \quad$ years

ous adverse event

(median follow-up: 26 weeks)

*The basis for the assumed risk (e.g. the median control group risk across studies) is provided in footnotes. The corresponding risk (and its $95 \%$ confidence interval) is based on the assumed risk in the comparison group and the relative effect of the intervention (and its $95 \% \mathrm{Cl}$ ).

Cl: confidence interval; NNTB: number needed to treat for an additional beneficial outcome; RR: risk ratio; SMD: standardised mean difference; VAS: visual analogue scale; WOMAC: Western Ontario and McMaster Universities Arthritis Index

GRADE Working Group grades of evidence

High quality: Further research is very unlikely to change our confidence in the estimate of effect.

Moderate quality: Further research is likely to have an important impact on our confidence in the estimate of effect and may change the estimate.

Low quality: Further research is very likely to have an important impact on our confidence in the estimate of effect and is likely to change the estimate.

Very low quality: We are very uncertain about the estimate.

${ }^{1}$ Median reduction as observed across placebo groups in large osteoarthritis trials (see methods section, Nüesch 2009).

${ }^{2}$ SMDs were back-transformed onto a 10-cm visual analogue scale (VAS) on the basis of a typical pooled standard deviation (SD) of $2.5 \mathrm{~cm}$ in large trials that assessed pain using a VAS and expressed as change based on an assumed standardised reduction of 0.72 SD units in the control group.

${ }^{3}$ Percentage of improvement was calculated based on median observed pain at baseline across control groups of large 0 steoarthritis trials of $6.1 \mathrm{~cm}$ on 10 -cm VAS (Nüesch 2009).

${ }^{4}$ Absolute response risks for pain in the control groups were assumed $31 \%$ (see methods section)

5 SMDs were back-transformed onto a standardised Western Ontario and McMaster Universities Arthritis Index (WOMAC) disability score ranging from 0 to 10 on the basis of a typical pooled

SD of 2.1 in trials that assessed function using WOMAC disability scores and expressed as change based on an assumed standardised reduction of 0.58 SD units in the control group.

${ }^{6}$ Percentage of improvement was calculated based on median observed WOMAC function scores at baseline across control groups of large osteoarthritis trials of 5.6 units (Nüesch 2009 ).

${ }^{7}$ Absolute response risks for function in the control groups were assumed $26 \%$ (see methods section).

${ }^{8}$ Median control risk across placebo groups in large osteoarthritis trials (see methods section, Nüesch 2009).

${ }^{9}$ Downgraded (2 levels) because: Most studies that reported this outcome are of high or unclear risk of bias, and statistical heterogeneity is large

${ }^{10}$ Downgraded (3 levels) because: $50 \%$ or more of the studies that reported this outcome are of high or unclear risk of bias, and the confidence interval of the pooled estimate is wide and includes the null effect 


\section{B A C K G ROU N D}

\section{Description of the condition}

Knee osteoarthritis is a leading cause of chronic disability in the United States (Felson 2000; Felson 2000a). It results from a multitude of both local and systemic factors. Progression of the disease leads to cartilage degeneration and thinning of the joint surface with subsequent joint pain and stiffness (Brandt 1996).

\section{Description of the intervention}

Intra-articular corticosteroid therapy has been used in knee osteoarthritis for over 50 years. The first clinical trial of intra-articular corticosteroids in knee osteoarthritis was performed in 1958 by Miller and colleagues (Miller 1958). Corticosteroids are available in both crystalline and non-crystalline forms. The crystalline triamcinolone and the non-crystalline prednisolone and methylprednisolone are used most frequently. Although this review is restricted to osteoarthritis of the knee joint, intra-articular corticosteroids have also been evaluated in osteoarthritis of various other joints (McColl 2000; Rozental 2000).

\section{How the intervention might work}

Although osteoarthritis is generally thought to be of degenerative rather than inflammatory origin, there is evidence that an inflammatory component may be present in at least some phases of the disease (Creamer 1997). Corticosteroids are known as potent antiinflammatory agents that act through a variety of mechanisms on different cellular levels.

\section{Why it is important to do this review}

The 2012 American College of Rheumatology (ACR) guidelines recommend the participation in exercise programs as well as weight loss (for overweight patients) as first-line treatments for symptomatic knee osteoarthritis. There is no strong recommendation for any pharmacological treatment other than over-the-counter paracetamol or nonsteroidal anti-inflammatory drugs. However, for people unresponsive to the basic treatment, there is a conditional, weak recommendation for the use of intra-articular corticosteroids (Hochberg 2012). Despite the long-standing use of intra-articular corticosteroids, there is an ongoing debate about their effectiveness and safety. Concerns have been expressed that intraarticular corticosteroids might mask the pain, enabling patients to prematurely mobilise and hereby promoting further destruction of the joint (Brandt 2001)

\section{O B J E C T I V E S}

To determine the benefits and harms of intra-articular corticosteroids compared with sham or no intervention in people with knee osteoarthritis in terms of pain, physical function, quality of life, and safety.

\section{METHODS}

\section{Criteria for considering studies for this review}

\section{Types of studies}

Randomised or quasi-randomised controlled trials with a control group receiving sham or no intervention.

\section{Types of participants}

At least $75 \%$ of participants with clinically or radiologically confirmed osteoarthritis of the knee. We did not consider trials that included exclusively people with inflammatory arthritis, such as rheumatoid arthritis.

\section{Types of interventions}

The experimental intervention of interest is any type of intraarticular corticosteroid. The control interventions of interest are sham intra-articular corticosteroid and no intervention.

\section{Types of outcome measures}

\section{Primary outcomes}

The main outcomes were pain and function, as currently recommended for osteoarthritis trials (Altman 1996; Pham 2004), reported within four and six weeks after end of treatment. If data on more than one pain scale were provided for a trial, we referred to a previously described hierarchy of pain-related outcomes (Jüni 2006; Reichenbach 2007), and extracted data on the pain scale that was highest on this list:

1. global pain;

2. pain on walking;

3. Western Ontario and McMaster Universities Arthritis Index (WOMAC) osteoarthritis index pain subscore;

4. composite pain scores other than WOMAC;

5. pain on activities other than walking;

6. rest pain or pain during the night;

7. WOMAC global algofunctional score;

8. Lequesne osteoarthritis index global score;

9. other algofunctional scale; 
10. participant's global assessment;

11. physician's global assessment.

If data on more than one function scale were provided for a trial, we extracted data according to the hierarchy:

1. global disability score;

2. walking disability;

3. WOMAC disability subscore;

4. composite disability scores other than WOMAC;

5. disability other than walking;

6. WOMAC global scale;

7. Lequesne osteoarthritis index global score;

8. other algofunctional scale;

9. participant's global assessment;

10. physician's global assessment

\section{Secondary outcomes}

Secondary outcomes were pain and function assessed at 1 to 2 , 4 to 6,13 , and 26 weeks after end of treatment, quality of life assessed at 1 to 2,4 to 6,13 , and 26 weeks, and the following safety outcomes: joint space narrowing assessed at 1 to 2,4 to 6,13 , and 26 weeks; the number of participants who experienced any adverse event; withdrew because of adverse events; and experienced any serious adverse events. We defined serious adverse events as events resulting in hospitalisation, prolongation of hospitalisation, persistent or significant disability, congenital abnormality or birth defect of offspring, life-threatening events, or death.

\section{Search methods for identification of studies}

\section{Electronic searches}

Please see Bellamy 2006 for information on electronic searches applied in the previous version of this review. Here, we developed a new search strategy using the electronic databases the Cochrane Central Register of Controlled Trials (CENTRAL, Issue 1, 2015; mrw.interscience.wiley.com/cochrane/), MEDLINE, and EMBASE (Ovid SP platform). We did a top-up search in PubMed to capture citations not yet indexed in MEDLINE. We used a combination of text words and controlled terms (MeSH or MeSH-like terms), including truncated variations of preparation names and brand names combined with terms related to osteoarthritis. We applied a validated methodological filter for controlled clinical trials (Dickersin 1994; Lefebvre 2008). We have displayed the specific search algorithms in Appendix 1 and Appendix 2. We performed the searches from inception to 3 February 2015.

\section{Searching other resources}

We manually searched the proceedings of the European League Against Rheumatism at http://www.abstracts2view.com/eular/ sessionindex.php, the American College of Rheumatology at http://acrannualmeeting.org/abstracts/abstract-archives/ (we no longer have access to Osteoarthritis Research Society International); used Science Citation Index to retrieve reports citing relevant articles; contacted content experts and trialists; and screened reference lists of all obtained articles. We also retrieved and screened systematic reviews published since January 2004 that evaluated the effects and safety of corticosteroid injections for knee osteoarthritis (Abdulla 2013; Arroll 2004; Avouac 2010; Bannuru 2015; Bellamy 2006; Bjordal 2007; Cheng 2012; Garg 2014; Godwin 2004; Hepper 2009; Hirsch 2013; Maricar 2013). Finally, we searched the following clinical trial registries: ClinicalTrials.gov, metaRegister of Controlled Trials (http://www.controlledtrials.com/), Australian New Zealand Clinical Trials Registry ( http://www.anzctr.org.au/TrialSearch.aspx), and UMIN Clinical Trials Registry (http://www.umin.ac.jp/ctr)) to identify ongoing trials. We performed the last update of the search on 26 March 2015.

\section{Data collection and analysis}

We used a generic protocol with instructions for data extraction, quality assessment, and statistical analyses, which we also used in our previous Cochrane reviews (da Costa 2012; da Costa 2014; Reichenbach 2010; Rutjes 2009; Rutjes 2009a; Rutjes 2010).

\section{Selection of studies}

Please see Bellamy 2006 for information on the selection of studies in the original review. In this review update, two out of three review authors independently evaluated all titles and abstracts for eligibility (MGS, MdN and AR). We resolved disagreements by discussion. We applied no language restrictions. If multiple reports described the same trial, we considered all.

\section{Data extraction and management}

Please see Bellamy 2006 for information on data extraction and management in the original review. In this review update, two out of three review authors (BDC, RF, RH) extracted trial information independently and in duplicate using a standardised, piloted extraction form accompanied by a codebook. We resolved disagreements by discussion. We extracted characteristics of the experimental intervention (ultrasound-guided injection, use of local anesthetic, crystalline preparation, and prednisolone equivalance), the type of control used, dosage, frequency, duration of treatment, participant characteristics, types of measures used and pain-, function-, and quality of life-related outcomes, trial design, trial size, duration of follow-up, type and source of financial support, and publication status. When necessary, we approximated means and measures of dispersion from figures in the reports. For cross-over trials, we extracted data from the first period only. Whenever possible, we used results from an intention-to-treat analysis. 


\section{Assessment of risk of bias in included studies}

Two out of three review authors (BDC, RF, RH) assessed randomisation, blinding, and adequacy of analyses independently and in duplicate (Jüni 2001). We resolved disagreements by consensus. We assessed two components of randomisation: generation of allocation sequences and concealment of allocation. We considered generation of sequences to be adequate if it resulted in an unpredictable allocation schedule; mechanisms considered adequate included random-number tables, computer-generated random numbers, minimisation, coin tossing, shuffling cards, and drawing lots. We considered trials using an unpredictable allocation sequence to be randomised and trials using potentially predictable allocation mechanisms, such as alternation or the allocation of participants according to date of birth to be quasi-randomised. We considered concealment of allocation to be adequate if participants and investigators responsible for participant selection were unable to suspect before allocation which treatment was next. Methods considered adequate included central randomisation; pharmacy-controlled randomisation using identical, prenumbered containers; and sequentially numbered, sealed, opaque envelopes. We considered blinding of participants to be adequate if a sham injection was used with a syringe that was identical in appearance to the control intervention, or an attempt was made to hide the participant's view of the injected knee by placing screens, for example. We considered blinding of therapists to be adequate if a credible blinding attempt was described, such as the use of independently prepared, opaque syringes. We considered analyses to be performed according to the intention-to-treat principle if all randomised participants were included in the analysis. We further assessed the reporting of primary outcomes, sample size calculations, and funding source. Finally, we used GRADE to describe the quality of the overall body of evidence (Guyatt 2008; Higgins 2011), defined as the extent of confidence into the estimates of treatment benefits and harms.

\section{Measures of treatment effect}

We summarised continuous outcomes using standardised mean differences (SMD) with 95\% confidence intervals (CI), with the differences in mean change from baseline values across treatment groups divided by the pooled standard deviation (SD). If differences in mean change were unavailable, we used differences in mean values at the end of the treatment (da Costa 2013). If some of the required data were unavailable, we used approximations, as previously described (Reichenbach 2007). An SMD of -0.20 SD units can be considered a small difference between the experimental and control groups, an SMD of -0.50 a moderate difference, and -0.80 a large difference (Cohen 1988; Jüni 2006). SMDs can also be interpreted in terms of the percent of overlap of the experimental group's scores with scores of the control group. An SMD of -0.20 indicates an overlap in the distribution of pain or function scores in about $85 \%$ of cases, an SMD of -0.50 in about $67 \%$, and an SMD of -0.80 in about $53 \%$ of cases (Cohen 1988; Jüni 2006). On the basis of a median pooled SD of $2.5 \mathrm{~cm}$, found in largescale osteoarthritis trials that assessed pain using a $10-\mathrm{cm}$ visual analogue scale (VAS) (Nüesch 2009), SMDs of -0.20 correspond to approximate differences in pain scores between experimental and control groups of $0.5 \mathrm{~cm}$ on a 10-cm VAS, -0.50 of $1.25 \mathrm{~cm}$, and -0.80 of $2 \mathrm{~cm}$. We back transformed SMDs for function to a standardised WOMAC disability score (Bellamy 1995), ranging from 0 to 10 on the basis of a median pooled SD of 2.1 units observed in large-scale osteoarthritis trials (Nüesch 2009). We expressed binary outcomes as risk ratios (RR) with $95 \% \mathrm{CI}$.

\section{Data synthesis}

We used a standard inverse-variance random-effects meta-analysis to combine the trials (DerSimonian 1986). We quantified heterogeneity between trials using the $\mathrm{I}^{2}$ statistic (Higgins 2003), which describes the percentage of variation across trials that is attributable to heterogeneity rather than to chance. $\mathrm{I}^{2}$ values of $25 \%$ may be interpreted as low, 50\% as moderate, and 75\% as high betweentrial heterogeneity ( $\mathrm{da}$ Costa 2014a), although interpretation of $\mathrm{I}^{2}$ depends on the size and number of trials included (Rucker 2008). Each trial contributed once to our main effectiveness analyses with the effect estimate closer to our primary time point of interest at four to six weeks. We investigated the association between trial size and treatment effects in contour-enhanced funnel plots (Peters 2008), plotting effect sizes on the vertical axis against their standard errors on the horizontal axis (Sterne 2001; Sterne 2011; Thompson 1999), accompanied by a regression test for asymmetry (Egger 1997). We then performed stratified analyses of the primary outcomes, pain and function, accompanied by interaction tests according to the following trial characteristics: concealment of allocation (adequate versus inadequate or unclear), blinding of participants (adequate versus inadequate or unclear), blinding of therapists (adequate versus inadequate or unclear), type of control (placebo versus no intervention), analysis in accordance with the intention-to-treat principle (yes versus no or unclear), trial size, funding (funding independent of industry versus industry or unclear source of funding), publication type (full journal article versus other type or unpublished material), ultrasound-guidance of injections (yes versus no or unclear), use of local anaesthetic (yes versus no or unclear), use of crystalline preparation (yes versus no or unclear), prednisolone equivalence dose ( $\geq 50 \mathrm{mg}$ versus $<50 \mathrm{mg}$ ), use of intra-articular viscosupplementation as co-intervention (yes versus no or unclear), and use of joint lavage as cointervention (yes versus no or unclear). We prespecified a cutoff of 100 allocated participants per trial arm to distinguish between small and large trials. A sample size of $2 \times 100$ participants will yield more than $80 \%$ power to detect a small to moderate SMD of -0.40 at a two-sided P value of 0.05 , which corresponds to a difference of $1 \mathrm{~cm}$ on a 10-cm VAS between the experimental and control intervention (Nüesch 2010). Since only one large trial was available, we also used a less stringent cutoff of 50 participants 
per arm as previously described (Nüesch 2013). Two arms with 50 participants each will yield more than $80 \%$ power to detect a moderate to large SMD of -0.60 . We calculated prednisolone equivalence doses, with prednisolone $10 \mathrm{mg}$ considered equivalent to betametasone $1.6 \mathrm{mg}$, cortivazol $0.8 \mathrm{mg}$, dexamethasone 1.6 $\mathrm{mg}$, hydrocortisone $40 \mathrm{mg}$, methylprednisolone $8 \mathrm{mg}$, and triamcinolone $8 \mathrm{mg}$. Interaction tests were based on $\mathrm{z}$ scores of the difference in effect sizes between strata divided by the corresponding standard error.

We converted SMDs of pain intensity and function to number needed to treat for an additional beneficial outcome on pain or function as compared with placebo (NNTB), and number needed to treat for an additional harmful outcome (NNTH) (da Costa 2012a). We defined treatment response as a $50 \%$ improvement in scores (Clegg 2006; Dworkin 2008; Dworkin 2009). With a median standardised pain intensity at baseline of 2.4 SD units, observed in large osteoarthritis trials (Nüesch 2009), this corresponds to a mean decrease in scores of 1.2 SD units. Based on the median standardised decrease in pain scores of 0.72 SD units (Nüesch 2009), we calculated that a median of $31 \%$ of participants in the placebo group would achieve an improvement of pain scores of $50 \%$ or more. We used this percentage as the control group response rate to calculate NNTBs for pain. Based on the median standardised WOMAC function score at baseline of 2.7 SD units and the median standardised decrease in function scores of 0.58 SD units (Nüesch 2009), 26\% of participants in the placebo group would achieve a reduction in function of $50 \%$ or more. Again, we used this percentage as the control group response rate to calculate NNTBs for function. We used the median risks of 150 patients with adverse events per 1000 patient-years, four patients with serious adverse events per 1000 patient-years, and 17 dropouts due to adverse events per 1000 patient-years as observed in placebo groups in large osteoarthritis trials to calculate NNTHs for safety outcomes (Nüesch 2009). All P values were two-sided. We performed analyses using Review Manager 5.3 (RevMan 2014), and STATA version 14.0 (StataCorp, College Station, Texas).

\section{R E S U L T S}

\section{Description of studies}

\section{Results of the search}

We identified 2324 potentially relevant references through our electronic searches and 20 additional references through other sources (Figure 1). We excluded 1769 references after screening titles and abstracts and retrieved 154 potentially relevant references for full-text assessment. We included 33 reports on 27 RCTs in the review. 
Figure I. Study flow chart. *records with the exact same bibliographic information of another alreadyscreened record.

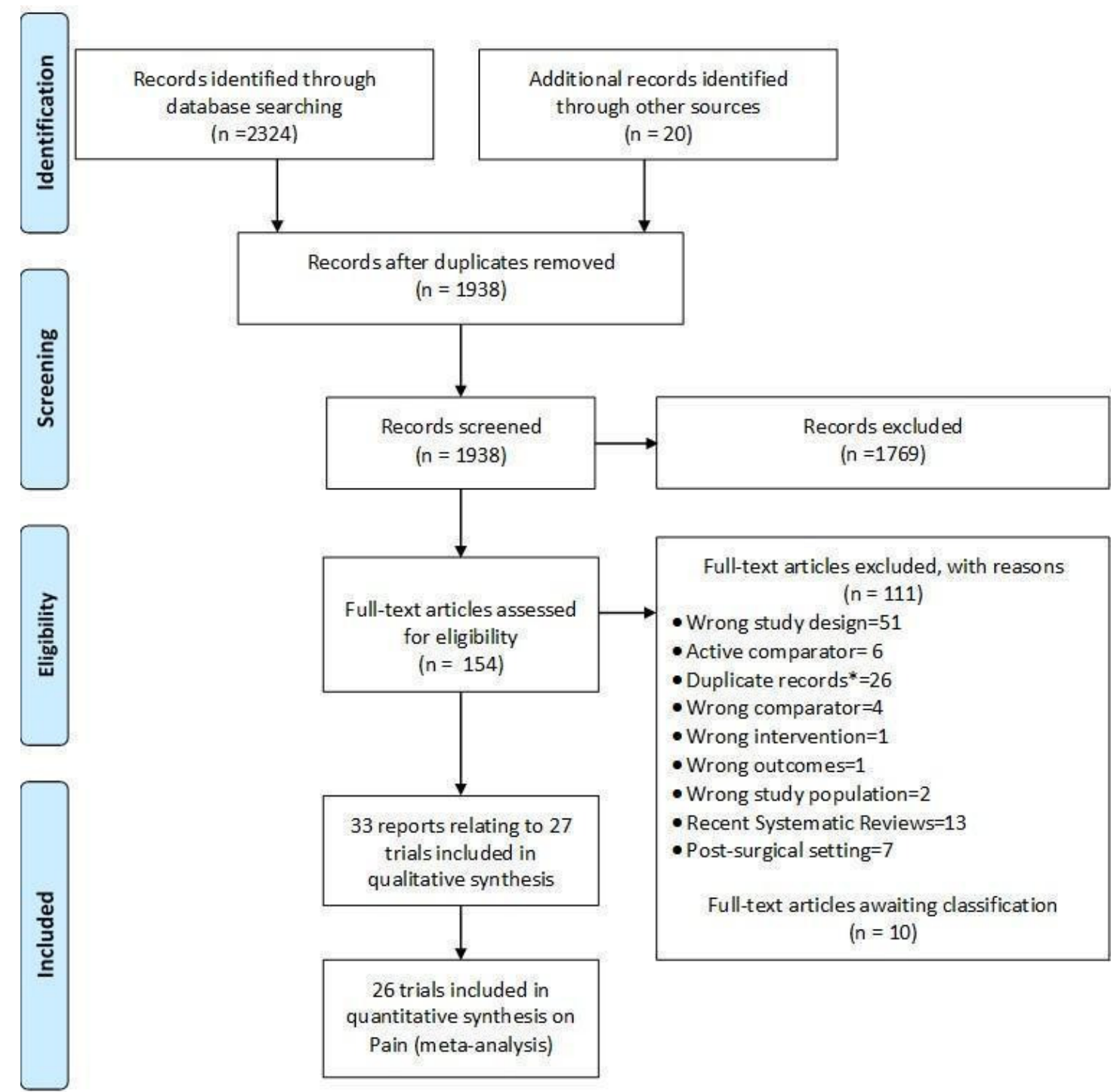

\section{Included studies}

Twenty-six trials reported effectiveness data. We included all 26 trials in the analysis of pain outcomes, 15 trials in the analysis of function outcomes (Beyaz 2012; Campos 2013; Castro 2007; Chao 2010; Di Sante 2012; Gaffney 1995; Henriksen 2015; Lyons 2005; Petrella 2015; Popov 1989; Ravaud 1999; Raynauld 2003; Smith 2003; Yavuz 2012; Young 2001), and two trials in the analysis of quality-of-life outcomes (Gaffney 1995; Henriksen 2015). Of the 26 included trials, 19 compared corticosteroid injection to sham injection (Beyaz 2012; Cederlof 1966; Chao 2010; Dieppe 1980; Friedman 1980; Gaffney 1995; Henriksen 2015; Jones 1996; NCT00414427; Lyons 2005; Miller 1958; Popov 1989; Ravaud 1999; Raynauld 2003; Schue 2011; Smith 2003; Yavuz 2012; Young 2001; Zhilyayev 2012), and 7 compared corticosteroid injection to no treatment (Campos 2013; Castro 2007; Di Sante 2012; Fri as 2004; Grecomoro 1992; Ozturk 2006; Petrella 2015).

Triamcinolone was used in 15 trials (Beyaz 2012; Campos 2013; Castro 2007; Chao 2010; Dieppe 1980; Fri as 2004; Friedman 
1980; Gaffney 1995; NCT00414427; Ozturk 2006; Petrella 2015; Popov 1989; Raynauld 2003; Yavuz 2012; Zhilyayev 2012), methylprednisolone in seven trials (Di Sante 2012; Henriksen 2015; Lyons 2005; Schue 2011; Smith 2003; Yavuz 2012; Young 2001), hydrocortisone in two trials (Miller 1958; Popov 1989), prednisolone in two trials (Cederlof 1966; Jones 1996), dexamethasonephosphate in one trial (Grecomoro 1992), betametazone disodium phosphate in one trial (Yavuz 2012), and cortivazol in one trial (Ravaud 1999). Four trials used viscosupplementation as a concomitant treatment (Campos 2013; Grecomoro 1992; Ozturk 2006; Petrella 2015), and four trials used lavage as a concomitant treatment (Castro 2007; Fri as 2004; Ravaud 1999; Smith 2003). Two trials used ultrasound to assure intra-articular delivery of corticosteroid preparation (Di Sante 2012; Henriksen 2015). The median prednisolone equivalence dose across all trials was 50 $\mathrm{mg}$, and the median number of corticosteroid injections was one. Trials randomised a median of 76 participants (range 16 to 205 participants).

One additional trial investigating hydrocortisone only reported safety data, on number of participants experiencing any adverse event (Wright 1960).

\section{Excluded studies}

The Characteristics of excluded studies table displays the reasons for excluding trials in this systematic review. Typical reasons were wrong study design, use of active control interventions, more than $25 \%$ of participants with rheumatoid arthritis in the sample, or the use of cross-over designs without providing sufficient information on the first phase.

\section{Risk of bias in included studies}

Figure 2 summarises the methodological characteristics and sources of funding of included trials. Two trials (7\%) reported both adequate sequence generation and adequate allocation concealment (Henriksen 2015; Smith 2003), and six trials reported only adequate sequence generation (Campos 2013; Cederlof 1966; Di Sante 2012; Ozturk 2006; Petrella 2015; Raynauld 2003). In the remaining 18 trials, low quality of reporting hampered any judgement regarding sequence generation and concealment of allocation. Six trials reported the use of indistinguishable interventions to blind participants, and three trials reported the use of indistinguishable interventions to blind therapists. Nine and five trials conducted analysis of pain and function outcomes according to the intention-to-treat principle, respectively. Eleven trials received financial support from a nonprofit organisation, and no trial was explicitly supported by a commercial organisation. Twenty-three trials used parallel-group randomisation, and two were cross-over trials (Dieppe 1980; Jones 1996). 
Figure 2. Risk of bias summary: review authors' judgements about each risk of bias item for each included study.

\begin{tabular}{|c|c|c|c|c|c|c|}
\hline & 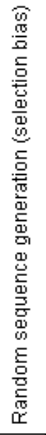 & 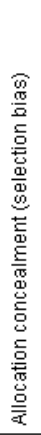 & 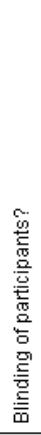 & 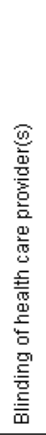 & 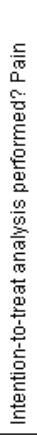 & 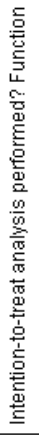 \\
\hline Beyaz 2012 & $?$ & $?$ & 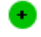 & + & - & \\
\hline Campos 2013 & + & $?$ & $\oplus$ & $?$ & $\odot$ & \\
\hline Castro 2007 & $?$ & $?$ & $?$ & $?$ & + & + \\
\hline Cederlof 1966 & + & $?$ & $?$ & $?$ & + & $?$ \\
\hline Chao 2010 & $?$ & $?$ & $\odot$ & - & 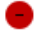 & \\
\hline Dieppe 1980 & $?$ & $?$ & - & ) & + & $?$ \\
\hline Di Sante 2012 & + & $?$ & $\odot$ & - & + & + \\
\hline Frías 2004 & $?$ & $?$ & $?$ & $?$ & C & $?$ \\
\hline Friedman 1980 & $?$ & $?$ & + & $\odot$ & + & $?$ \\
\hline Gaffiney 1995 & ? & ? & + & - & ? & $?$ \\
\hline Grecomoro 1992 & $?$ & $?$ & $\mathcal{-}$ & 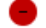 & + & $?$ \\
\hline Henriksen 2015 & + & + & $\odot$ & + & + & + \\
\hline Jones 1996 & ? & ? & $?$ & $?$ & $(-)$ & ? \\
\hline Lyons 2005 & $?$ & $?$ & ? & - & + & + \\
\hline Miller 1958 & $?$ & $?$ & $?$ & $?$ & - & ? \\
\hline NCT00414427 & $?$ & $?$ & ? & ? & - & ? \\
\hline Ozturk 2006 & + & $?$ & $?$ & $?$ & - & $?$ \\
\hline Petrella 2015 & + & ? & ? & - & - & 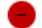 \\
\hline Popov 1989 & $?$ & $?$ & $?$ & $?$ & $?$ & $?$ \\
\hline Ravaud 1999 & ? & ? & ? & ? & + & + \\
\hline Raynauld 2003 & + & $?$ & $?$ & - & - & \\
\hline Schue 2011 & $?$ & $?$ & $?$ & $?$ & $?$ & $?$ \\
\hline Smith 2003 & + & + & $?$ & $?$ & $\odot$ & $\odot$ \\
\hline Wright 1960 & ? & $?$ & $?$ & $?$ & ? & ? \\
\hline Yavuz 2012 & - & $?$ & $?$ & $?$ & $?$ & $?$ \\
\hline Young 2001 & $?$ & ? & $?$ & $?$ & $?$ & ? \\
\hline Zhilyayev 2012 & $?$ & $?$ & $?$ & $?$ & $?$ & $?$ \\
\hline
\end{tabular}


For the effectiveness outcomes pain and function, we classified the quality of the evidence as low in view of the high risk of bias in the included trials and the high heterogeneity between trials (Summary of findings for the main comparison) (Guyatt 2008). For adverse event, dropouts due to adverse events, and serious adverse event outcomes, we classified the quality of the evidence as low because of the small number of trials reporting the outcomes and the small number of overall events, which resulted in imprecise estimates, and because we considered $50 \%$ or more of these trials to be at high risk of bias (Summary of findings for the main comparison) (Guyatt 2008).

\section{Effects of interventions}

See: Summary of findings for the main comparison

\section{Primary outcomes}

\section{Knee pain}

Figure 3 presents results of the overall analysis of knee pain reported closest to four to six weeks after end of treatment. Corticosteroids were more effective in pain reduction than control interventions (SMD $-0.40,95 \%$ CI -0.58 to -0.22 ), which corresponds to a difference in pain scores of $1.0 \mathrm{~cm}$ on a $10-\mathrm{cm}$ VAS between corticosteroids and sham injection. This corresponds to a difference in improvement of $17 \%$ (95\% CI $10 \%$ to $25 \%$ ) between corticosteroids and sham injection (Summary of findings for the main comparison), which translates into a NNTB to cause one additional treatment response on pain of 8 (95\% CI 6 to 13) (Summary of findings for the main comparison). An $\mathrm{I}^{2}$ statistic of $68 \%$ indicated a moderate to large degree of between-trial heterogeneity ( $\mathrm{P}$ for heterogeneity $<0.001$ ). A visual inspection of the funnel plot suggested some asymmetry (asymmetry coefficient $1.21,95 \%$ CI -3.58 to 1.17 ), but the corresponding regression test for asymmetry indicated no evidence for asymmetry $(\mathrm{P}=0.30)$ (Figure 4).

Figure 3. Forest plot of comparison: I Pain, outcome: I.I Pain - Main.

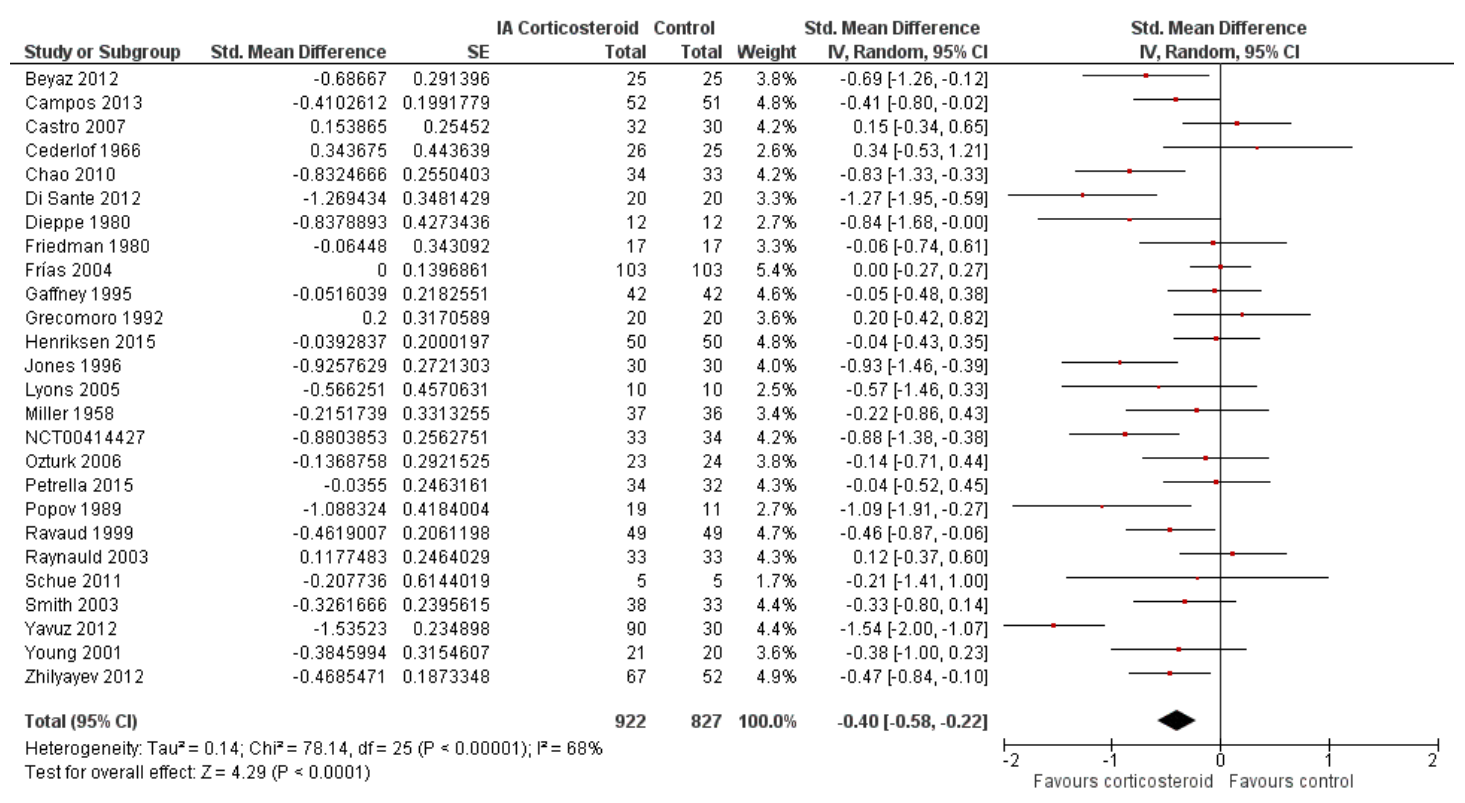

Intra-articular corticosteroid for knee osteoarthritis (Review) 
Figure 4. Contour-enhanced funnel plot for effects on knee pain. Numbers on $x$ axis refer to standardised mean differences (SMDs), on $y$ axis to standard errors of SMDs

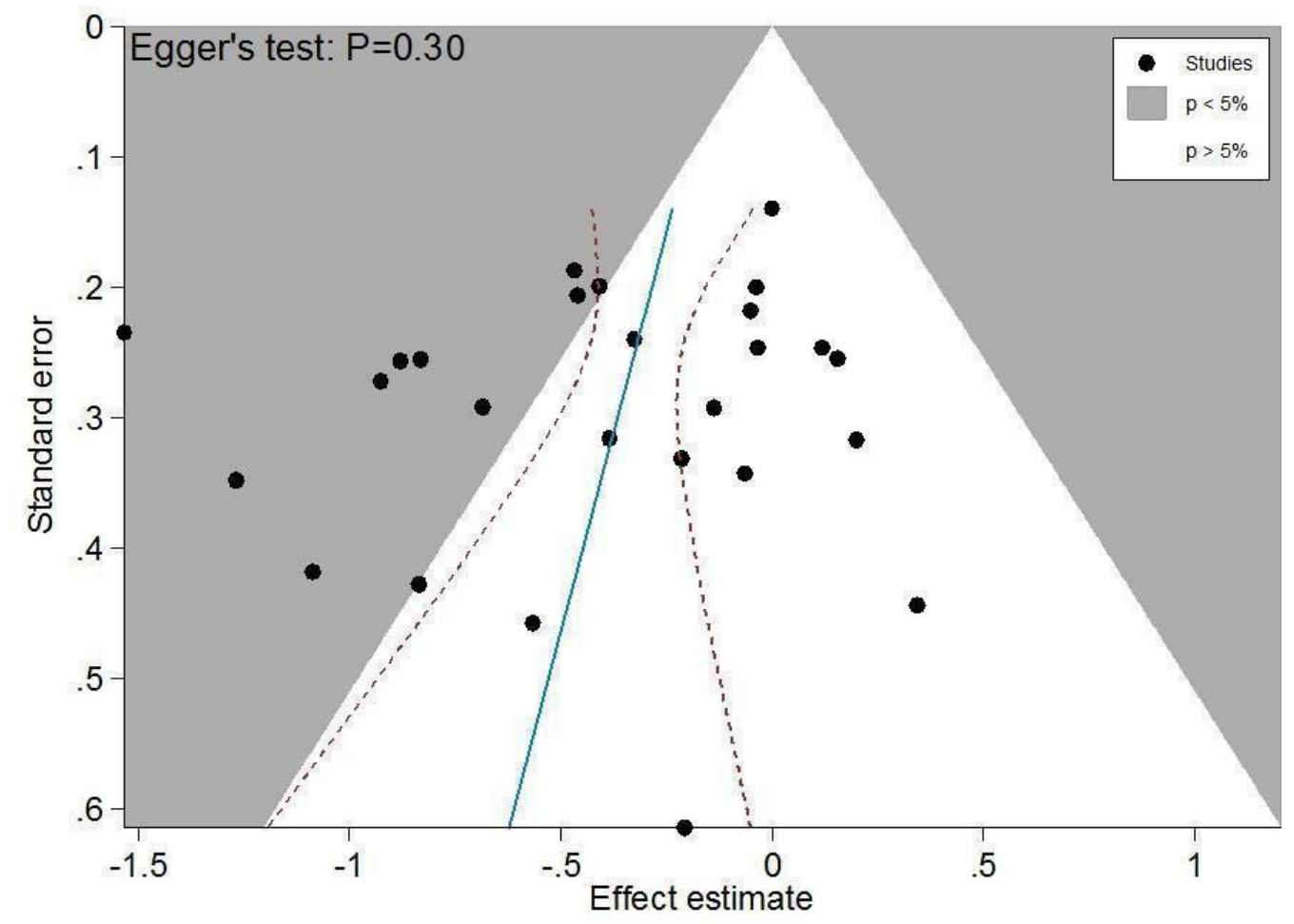

Figure 5 presents results stratified according to length of followup. Benefits were moderate at 1 to 2 weeks after end of treatment (SMD $-0.48,95 \%$ CI -0.70 to -0.27 ), small to moderate at 4 to 6 weeks (SMD $-0.41,95 \%$ CI -0.61 to -0.21 ), small at 13 weeks (SMD $-0.22,95 \%$ CI -0.44 to 0.00 ), and no effect at 26 weeks (SMD $-0.07,95 \%$ CI -0.25 to 0.11 ). An $I^{2}$ statistic of $\geq 63 \%$ indicated a moderate to large degree of between-trial heterogeneity up to 13 weeks after end of treatment ( $P$ for heterogeneity $\leq$ $0.001)$, and an $\mathrm{I}^{2}$ of $0 \%$ indicated low heterogeneity at 26 weeks ( $\mathrm{P}=0.43)$. 
Figure 5. Forest plot of comparison: I Pain, outcome: I.2 Pain - Time points. P for trend $=0.00$ I

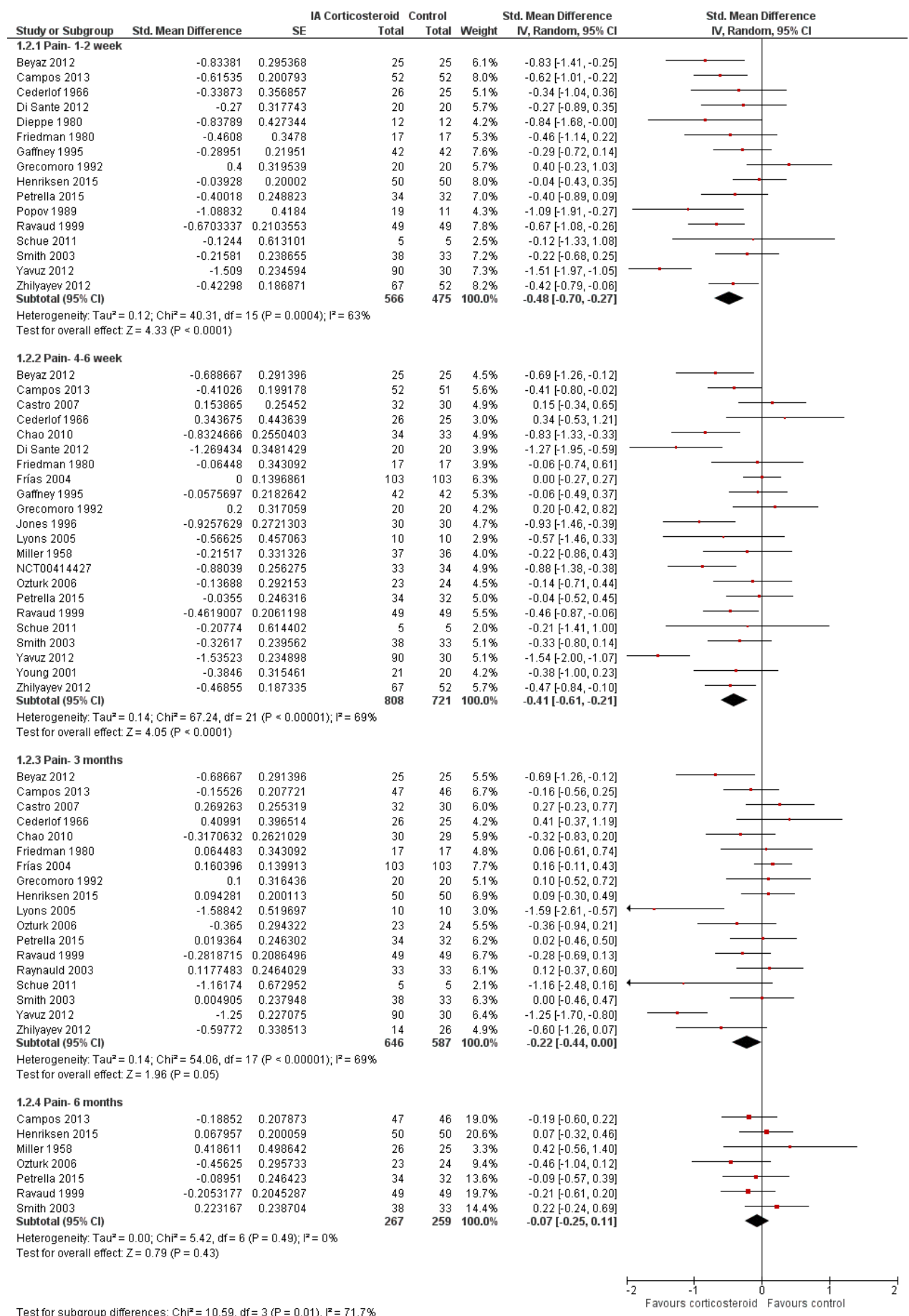

Intra-articular corticosteroid for knee osteoarthritis (Review) 
Table 1 presents the results of stratified analyses. We found little or no evidence for an association of SMDs with corticosteroid dosages, ultrasound guidance, local anesthetic, crystalline preparation, type of control intervention, financial support, publication type, concealment of allocation, adequate blinding of participants or therapists, or intention-to-treat analysis $(\mathrm{P} \geq 0.10)$. There was some evidence of lower treatment effects in trials that randomised on average at least 50 participants per group $(\mathrm{P}=0.05)$, or in trials that used viscosupplementation as a co-intervention $(\mathrm{P}=0.08)$. There was strong evidence of lower treatment effects in trials that randomised on average at least 100 participants per group $(\mathrm{P}=$ $0.013)$, or in trials that used joint lavage as a co-intervention $(\mathrm{P} \leq$ $0.001)$.

\section{Knee function}

Figure 6 presents results of the overall analysis of knee function reported closest to four to six weeks after end of treatment. Corticosteroids were more effective in function improvement than control interventions (SMD - 0.33, 95\% CI -0.56 to -0.09), which corresponds to a difference in functions scores of -0.7 units on standardised WOMAC disability scale ranging from 0 to 10 . This corresponds to a difference in improvement of $13 \%$ (95\% CI $4 \%$ to $22 \%$ ) between corticosteroids and sham injection (Summary of findings for the main comparison), which translates into a NNTB to cause one additional treatment response on function of 10 (95\% CI 7 to 33) (Summary of findings for the main comparison). An I 2 statistic of $69 \%$ indicated a moderate to large degree of betweentrial heterogeneity ( $\mathrm{P}$ for heterogeneity $<0.001)$. A visual inspection of the funnel plot suggested asymmetry (asymmetry coefficient $-4.07,95 \%$ CI -8.08 to -0.05$)$, and the test for asymmetry showed evidence for asymmetry $(\mathrm{P}=0.047)$ (Figure 7$)$.

Figure 6. Forest plot of comparison: 2 Function, outcome: 2.I Function - Main.

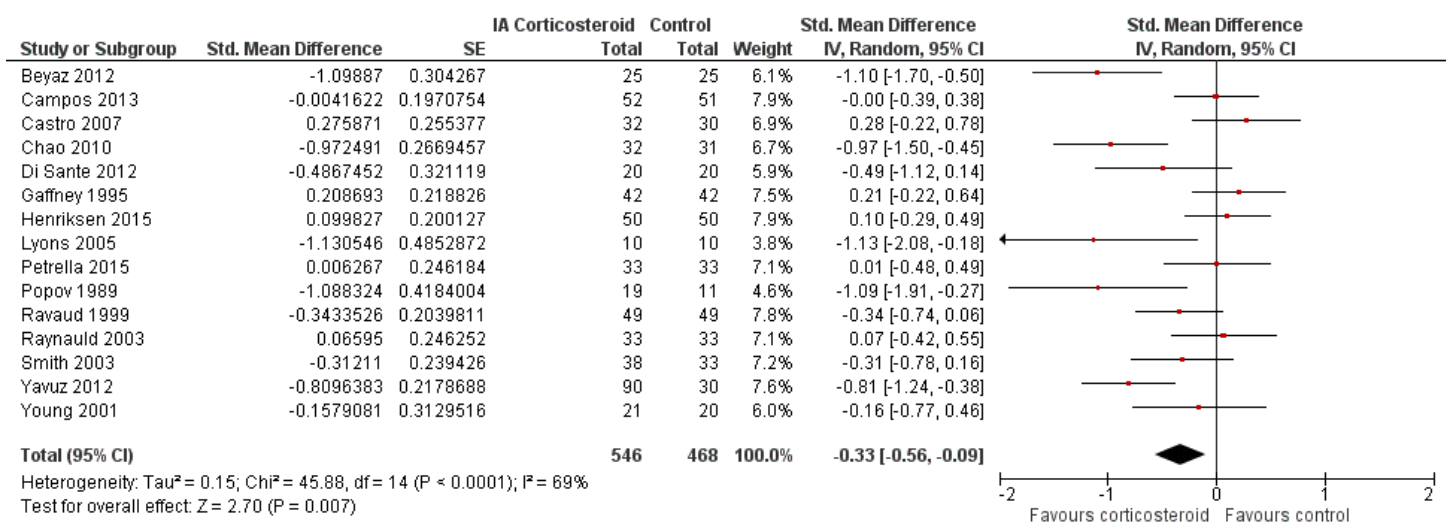

Intra-articular corticosteroid for knee osteoarthritis (Review) 
Figure 7. Contour-enhanced funnel plot for effects on knee function. Numbers on $x$ axis refer to standardised mean differences (SMDs), on y axis to standard errors of SMDs

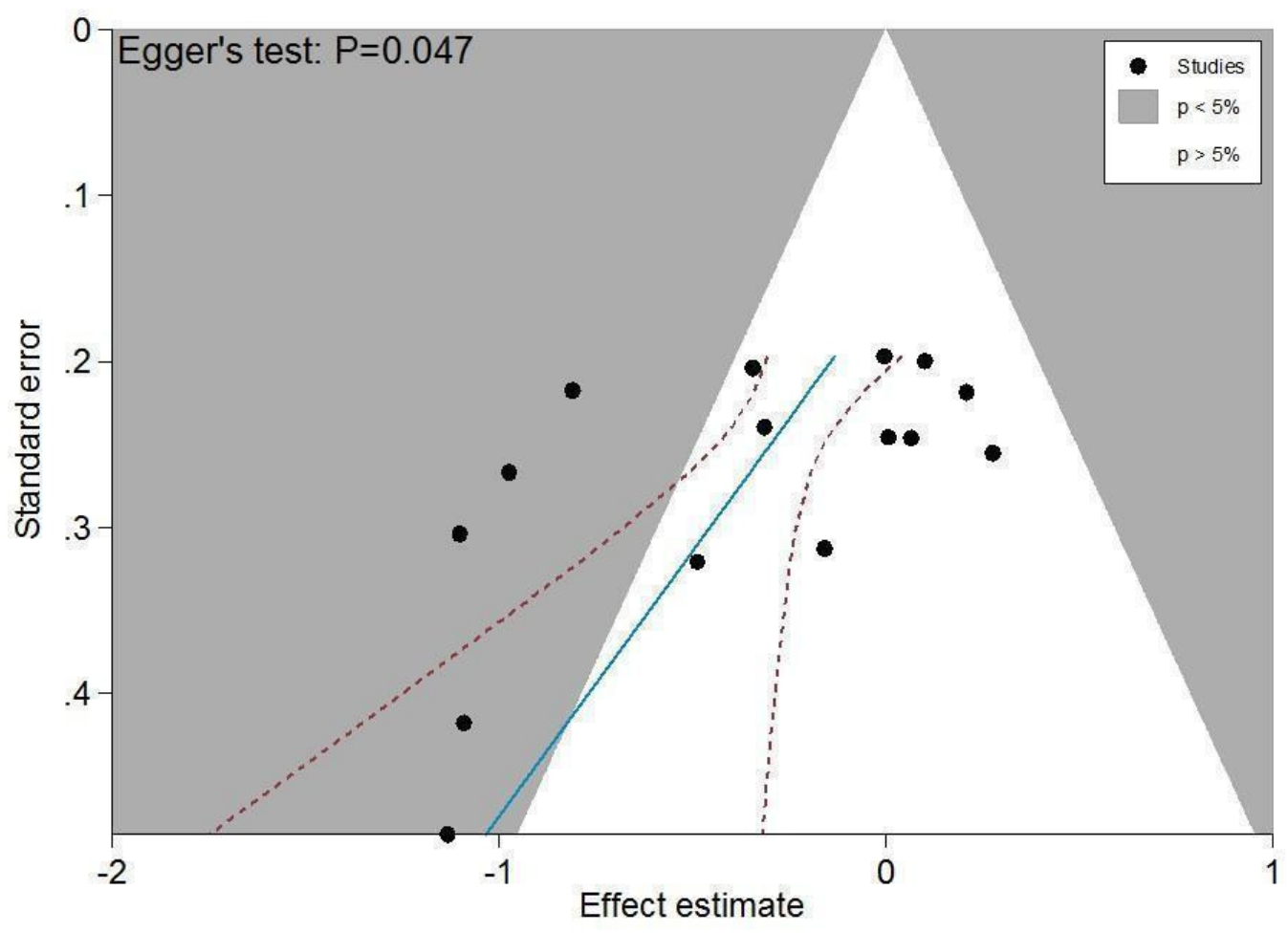

Figure 8 presents results stratified according to length of followup. Benefits were small to moderate at 1 to 2 weeks after end of treatment (SMD $-0.43,95 \%$ CI -0.72 to -0.14 ), small at 4 to 6 weeks (SMD -0.36, 95\% CI -0.63 to -0.09), no effect at 13 weeks (SMD $-0.13,95 \% \mathrm{CI}-0.37$ to 0.10 ), and no effect at 26 weeks (SMD $0.06,95 \%$ CI -0.16 to 0.28 ). An $\mathrm{I}^{2}$ statistic of $\geq 62 \%$ indicated a moderate to large degree of between-trial heterogeneity up to 13 weeks after end of treatment ( $P$ for heterogeneity $\leq$ $0.004)$, and an $\mathrm{I}^{2}$ of $0 \%$ indicated low heterogeneity at 26 weeks $(\mathrm{P}=0.52)$. 
Figure 8. Forest plot of comparison: 2 Function, outcome: 2.2 Function - Time points. $\mathbf{P}$ for trend $=0.0 \mathrm{I} \mathrm{I}$

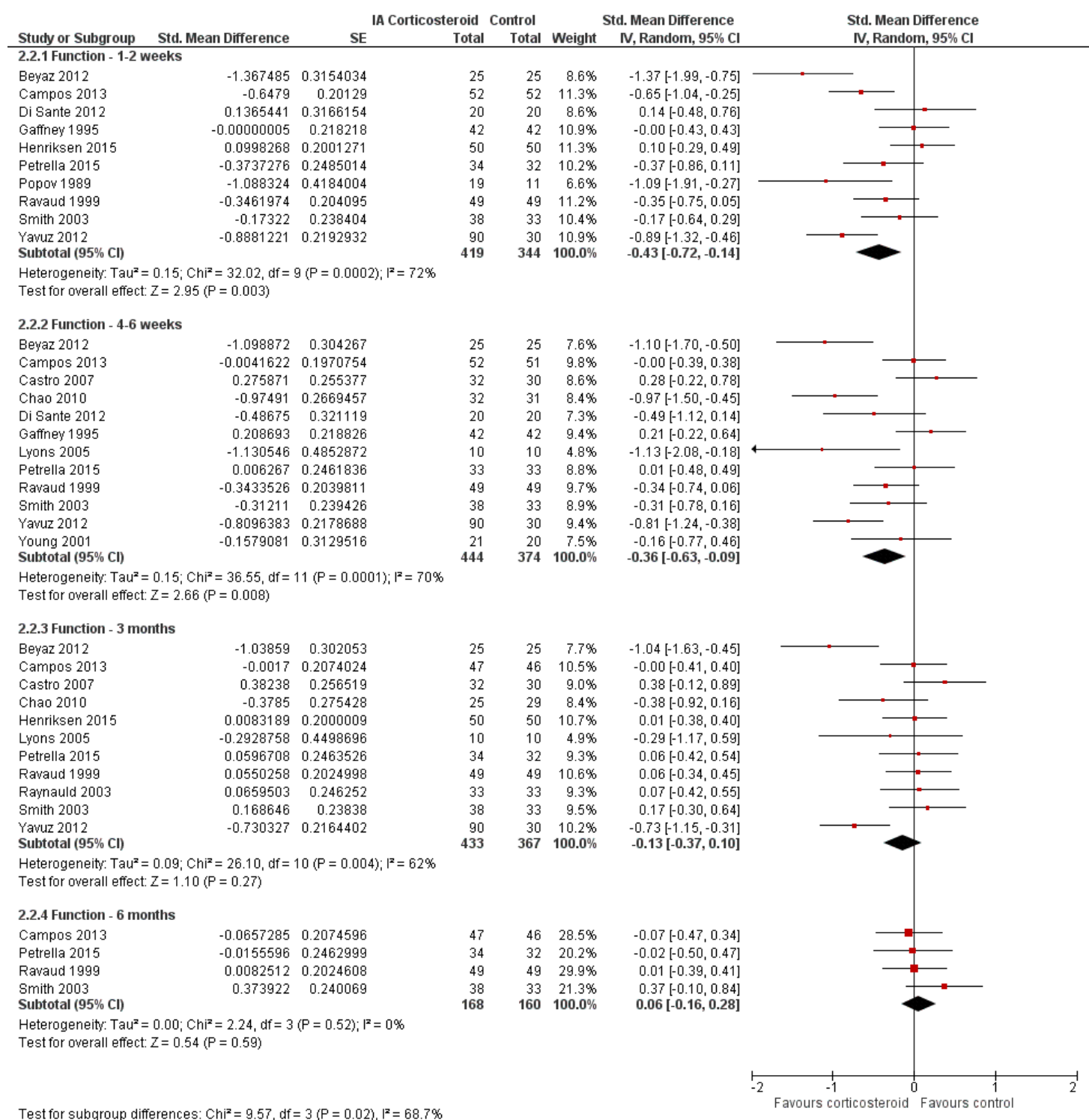

Table 2 presents the results of stratified analyses. We found little or no evidence for an association of SMDs with corticosteroid dosages, ultrasound guidance, local anaesthetic, crystalline preparation, joint lavage as a co-intervention, financial support, concealment of allocation, adequate blinding of participants or therapists, or intention-to-treat analysis $(P \geq 0.10)$. There was some evidence of lower treatment effects in trials that randomised on average at least 50 participants per group $(\mathrm{P}=0.023)$, in unpublished trials $(\mathrm{P}=0.023)$, in trials that used no intervention as control $(\mathrm{P}=$ $0.031)$, or in trials that used intra-articular viscosupplementation as a co-intervention $(\mathrm{P}=0.06)$.

\section{Secondary outcomes}

Figure 9 presents results of the overall analysis on quality of life reported closest to four to six weeks after end of treatment. Corticosteroids had no effect on quality of life compared to control interventions (SMD -0.01, 95\% CI -0.30 to 0.28). An $\mathrm{I}^{2}$ statistic of $0 \%$ indicated a low degree of between-trial heterogeneity (P for heterogeneity $=0.96)$. Figure 10 presents results of the overall 
analysis on joint space narrowing reported closest to four to six weeks after end of treatment. Corticosteroids had no effect in joint space narowing compared to control interventions (SMD -0.02, $95 \%$ CI -0.49 to 0.46 ). An I ${ }^{2}$ statistic was not estimable because only one trial was included in this analysis. There was not enough data to report results according to the pre-specified time points neither for quality of life nor joint space narrowing outcomes.

Figure 9. Forest plot of comparison: 3 Quality of life, outcome: 3.I Quality of life - Main.

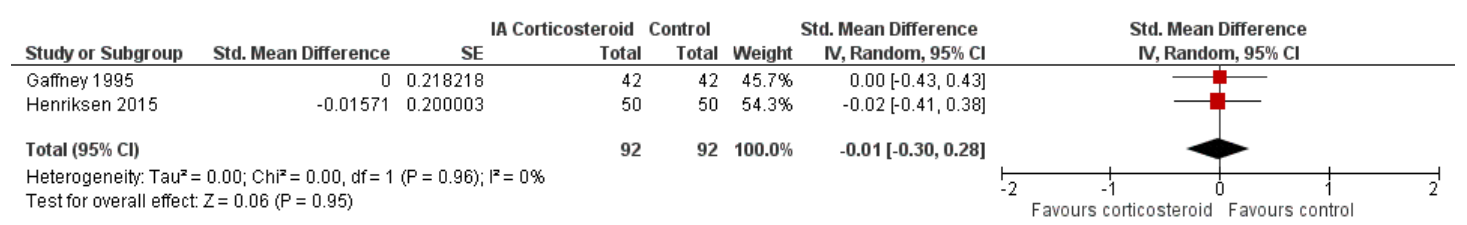

Figure 10. Forest plot of comparison: 7 Joint space narrowing, outcome: 7.I Joint space narrowing - Main.

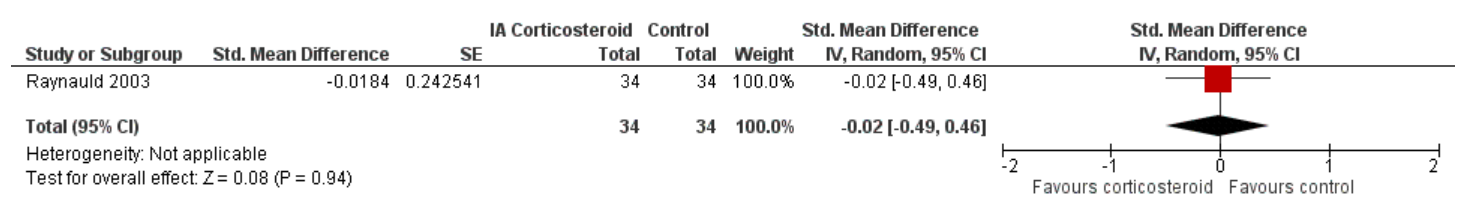

Figure 11 presents results of the overall analysis on number of participants experiencing any type of adverse event. We included 2 trials with a total of 84 participants and 46 events in this analysis. Participants on corticosteroids were $11 \%$ less likely to experience adverse events, but confidence intervals included the null effect (RR $0.89,95 \%$ CI 0.64 to 1.23 ). An $I^{2}$ statistic of $0 \%$ indicated a low degree of between-trial heterogeneity ( $\mathrm{P}$ for heterogeneity $=0.44)$. Due to the imprecision in results, we were not able to calculate meaningful NNTHs.

Figure I I. Forest plot of comparison: 4 Number of participants experiencing any adverse event, outcome: 4.I Number of participants experiencing any adverse event - Main.

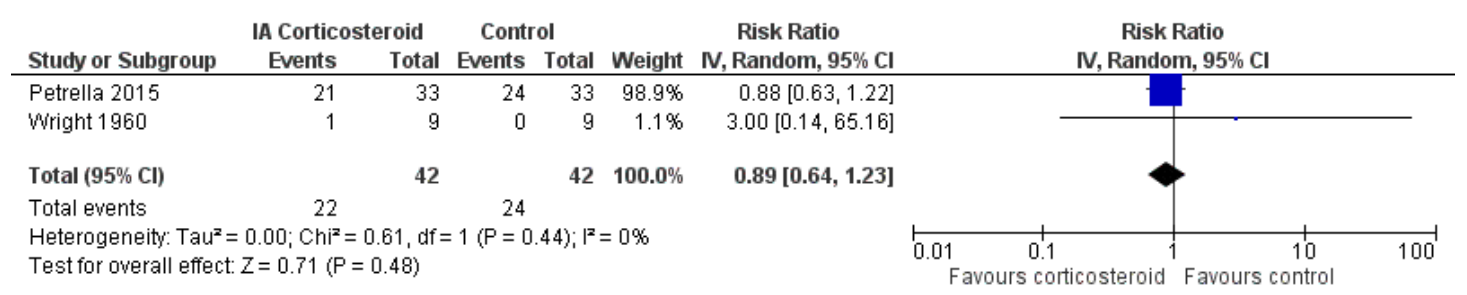

Intra-articular corticosteroid for knee osteoarthritis (Review) 
Figure 12 presents results of the overall analysis on number of participants who withdraw because of adverse events. We included 2 trials with a total of 204 participants and 5 events in this analysis. Participants on corticosteroids were $67 \%$ less likely to withdraw because of adverse events, but confidence intervals were wide and included the null effect (RR 0.33, 95\% CI 0.05 to 2.07). An I ${ }^{2}$ statistic of $0 \%$ indicated a low degree of between-trial heterogeneity $(\mathrm{P}$ for heterogeneity $=1.00)$. Due to the imprecision in results, we were not able to calculate meaningful NNTHs.

Figure I2. Forest plot of comparison: 5 Number of participants who withdraw because of adverse events, outcome: 5.I Number of participants who withdraw because of adverse events -Main.

\begin{tabular}{|c|c|c|c|c|c|c|c|c|c|}
\hline Study or Subgroup & \multicolumn{2}{|c|}{ IA Corticosteroid } & \multicolumn{2}{|c|}{ Control } & Weight & $\begin{array}{c}\text { Risk Ratio } \\
\text { IV, Random, } 95 \% \mathrm{Cl}\end{array}$ & \multicolumn{3}{|c|}{$\begin{array}{c}\text { Risk Ratio } \\
\text { IV, Random, } 95 \% \mathrm{Cl}\end{array}$} \\
\hline Campos 2013 & 0 & 52 & 1 & 52 & $33.0 \%$ & $0.33[0.01,8.00]$ & 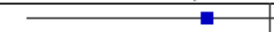 & & \\
\hline Henriksen 2015 & 1 & 50 & 3 & 50 & $67.0 \%$ & $0.33[0.04,3.10]$ & & & \\
\hline Total $(95 \% \mathrm{Cl})$ & & 102 & & 102 & $100.0 \%$ & $0.33[0.05,2.07]$ & & & \\
\hline Total events & 1 & & 4 & & & & & & \\
\hline $\begin{array}{l}\text { Heterogeneity: } \text { Tau }^{2} \\
\text { Test for overall effec }\end{array}$ & $\begin{array}{l}0.00 ; \mathrm{Chi}^{2} \\
\mathrm{Z}=1.18(\mathrm{P}\end{array}$ & $\begin{array}{l}00, \mathrm{df}= \\
.24)\end{array}$ & $=1(P=1$ & $.00) ; 1^{2}$ & $=0 \%$ & & $0.01 \quad 0.1$ & $\begin{array}{c}10 \\
\text { Favours control }\end{array}$ & 100 \\
\hline
\end{tabular}

Figure 13 presents results of the overall analysis on number of participants experiencing serious adverse events. We included 5 trials with a total of 331 participants and 8 events in this analysis. Participants on corticosteroids were $27 \%$ less likely to withdraw because of adverse events, but confidence intervals were wide and included the null effect (RR $0.63,95 \%$ CI 0.15 to 2.67). An I ${ }^{2}$ statistic of $0 \%$ indicated a low degree of between-trial heterogeneity ( $\mathrm{P}$ for heterogeneity $=0.46$ ). Due to the imprecision in results, we were not able to calculate meaningful NNTHs.

Figure 13. Forest plot of comparison: 6 Number of participants experiencing any serious adverse event, outcome: 6.I Number of participants experiencing any serious adverse event - Main.

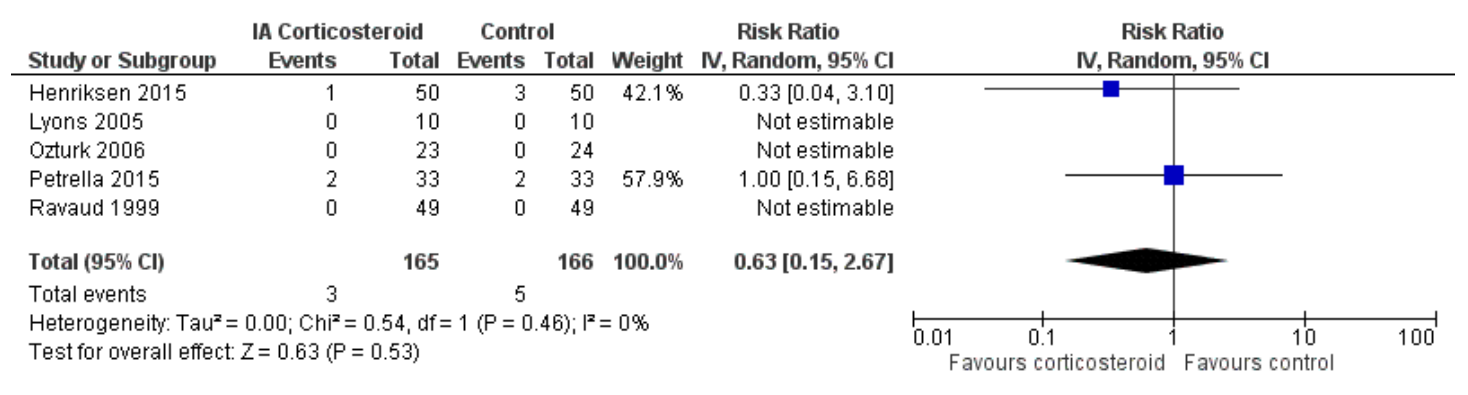

Intra-articular corticosteroid for knee osteoarthritis (Review) 


\section{Quality of the evidence (GRADE)}

We graded the quality of the evidence as 'low' for all outcomes because treatment effect estimates were inconsistent with great variation across trials, pooled estimates were imprecise and did not rule out relevant or irrelevant clinical effects, and because most trials had a high or unclear risk of bias.

\section{DISCUSSION}

\section{Summary of main results}

In this update of the systematic review and meta-analysis by Bellamy (Bellamy 2006), we found most of the identified trials that compared intra-articular corticosteroids with sham or non-intervention control to be small and hampered by low methodological quality, and graded the quality of evidence for the major outcomes as 'low'. Only one trial was considered large according to our prespecified criteria (Fri' as 2004), with an average sample size of 100 participants or more per group, but this trial did not report adequate randomisation, participant blinding, or an intention-totreat analysis. Conversely, only one trial reported adequate randomisation, participant blinding, and an intention-to-treat analysis (Henriksen 2015), but it was of moderate size only. An analysis of multiple time points suggested that effects decrease over time $(\mathrm{P} \leq 0.011)$, and our analysis provides no evidence that an effect remains six months after a corticosteroid injection. Whether there are clinically important benefits after one to six weeks remains unclear in view of the overall quality of the evidence. A single trial included in this review described adequate measures to consistently minimise biases (Henriksen 2015); this trial did not find any benefit of intra-articular corticosteroids (SMD 0.04, 95\% CI -0.43 to 0.35 ).

\section{Quality of the evidence}

The overall analyses of pain and function were difficult to interpret in view of the large extent of heterogeneity between trials. Stratified analyses suggested an association of estimates of treatment effects with sample size ( $\mathrm{P} \leq 0.05)$, and funnel plots appeared asymmetrical, even though the accompanying asymmetry test was positive only for function $(P=0.047)$. Stratified analyses according to components of methodological quality showed negative interaction tests. Conversely, trials with protocol-mandated concomitant lavage or viscosupplementation treatment in both experimental and control groups appeared to show smaller benefits of corticosteroids as compared with control.

The largest trial used joint lavage as concomitant treatment in all participants (Fri as 2004). It therefore ultimately remains unclear whether the lack of treatment effect in this trial is a function of study size in the presence of small-study effects (Nüesch 2010), or a function of the concomitant use of joint lavage, which may act as an effect modifier even in the absence of a specific therapeutic effect (Reichenbach 2010). However, among the three largest trials, which included at least 50 participants per group, only one used lavage (Fri as 2004), another used viscosupplementation as concomitant treatment (Campos 2013), and the third used neither (Henriksen 2015). When pooling these moderate-to-large trials, we found only a small, clinically irrelevant, and statistically nonsignificant effect on pain and function with a low degree of heterogeneity.

For other clinical characteristics including the use of ultrasound to guide injections, crystalline preparations, and prednisone equivalent doses, we did not find a treatment by subgroup interaction. Only two trials used ultrasound guidance to ensure proper placement of needles (Di Sante 2012, Henriksen 2015), however contradictory results and insufficient data are available to determine whether ultrasound guidance is associated with larger treatment effects.

\section{Potential biases in the review process}

We based our review on an extensive literature search, and so it seems unlikely that we missed relevant trials, provided that they were published as full-text articles or accessible in conference proceedings or trial registries (Egger 2003). Two review authors independently performed selection of trials and data extraction in order to reduce bias and transcription errors (Egger 2001; Gøtzsche 2007). We are therefore confident that potential biases during the review process were minimised.

\section{Agreements and disagreements with other studies or reviews}

Our update of the previous systematic review and meta-analysis by Bellamy identified 14 new trials that compared intra-articular corticosteroids with sham or non-intervention control (Bellamy 2006). In view of the overall body of evidence, we are as confident as Bellamy et al that no effect of intra-articular corticosteroids remains after six months, but are less confident than Bellamy that there is a clinically relevant short-term effect in view of large heterogeneity and possible small-study effects.

The most recent systematic review and network meta-analysis on intra-articular corticosteroids in knee osteoarthritis (Bannuru 2015), carried out in August 2014, identified seven trials comparing intra-articular corticosteroids to intra-articular placebo, all of which we included in our analysis. Again, we are less confident than these authors that there is a clinically relevant shortterm effect of intra-articular corticosteroids considering the issues described above. 


\section{AUTHORS' CONCLUSIONS}

\section{Implications for practice}

It remains unclear whether there are clinically important benefits one to six weeks after corticosteroid injection in view of the low quality of the included trials, the large amount of heterogeneity, and the likely presence of small-study effects (Nüesch 2010). Intra-articular corticosteroids should therefore be considered experimental in knee osteoarthritis and not be routinely used until adequately powered and properly designed trials clearly indicate a short- to mid-term benefit.

\section{Implications for research}

An adequately designed, multicentre, randomised, double-blind, sham-controlled, parallel-group trial is required to confirm or refute clinically relevant short- to mid-term benefits of intra-articu- lar corticosteroids in knee osteoarthritis. A sample size of 100 participants per group would yield $80 \%$ power to detect a clinically meaningful moderate effect size of 0.4 standard deviation units in terms of pain reduction. The trial should use ultrasound guidance to ensure intra-articular needle placement as recently described by Henriksen et al (Henriksen 2015).

\section{ACKNOWLEDGEMEN T S}

We acknowledge Dr. med. Marcello Di Nisio for his contribution with reference screening. We are grateful to Dr. Janne Estill and Elena Jüni for their translation of the Popov 1989 trial. We would also like to acknowledge the authors of the original version of this review: Nicholas Bellamy, Jane Campbell, Vivian Welch, Travis L Gee, Robert Bourne, and George A Wells.

\section{R E F E R E N C E S}

\section{References to studies included in this review}

Beyaz 2012 \{published data only\}

* Beyaz S G. Comparison of efficacy of intra-articular morphine and steroid in patients with knee osteoarthritis. Journal of Anaesthesiology Clinical Pharmacology 2012;28(4): 496-500.

Campos 2013 \{published data only\}

Campos G C. Evaluation of the effect of adding corticosteroid to viscosupplementation: A prospective and randomized study. Osteoarthritis and Cartilage 2011;19: S236.

Campos G C, Rezende M U, Fruchi R, Pasqualin T, Hissadomi M I. Adding triamcinolone to viscosupplementation: One year outcome of randomized trial. Osteoarthritis and Cartilage 2014;22:S198.

* Campos G C, Rezende M U, Pailo A F, Frucchi $\mathrm{R}$, Camargo O P. Adding triamcinolone improves viscosupplementation: A randomized clinical trial. Clinical Orthopaedics and Related Research 2013;471(2):613-20. Campos G C, Rezende M U, Pailo A F, Frucchi R, Pasqualin T. Evaluation of the effect of adding corticosteroid to viscosupplementation: A prospective and randomized study. Osteoarthritis and Cartilage 2012;20:S169-70.

Castro 2007 \{published data only\}

* Castro M, Font P, Escudero A, Frias G, Mun

- oz E, Collantes E. Evaluation of effectiveness of five modalities of intraarticular treatment in patients with osteoarthritis of the knee. Annals of the Rheumatic Diseases 2007;66(Suppl II):515.

Cederlof 1966 \{published data only\}

* Cederlof S, Jonson G. Intraarticular prednisolone injection for osteoarthritis of the knee. A double blind test with placebo. Acta Chirurgica Scandinavica 1966;132(5):532-7.
Chao 2010 \{published data only\}

* Chao J, Wu C, Sun B, Hose M K, Quan A, Hughes T H, et al. Inflammatory characteristics on ultrasound predict poorer long-term response to intraarticular corticosteroid injections in knee osteoarthritis. Journal of Rheumatology 2010;37(3):650-5.

Chao J, Wu C, Sun B, Hose M, Quan A, May S, et al. Inflammatory characteristics on ultrasound predict poorer long-term response to intraarticular corticosteroid injections in knee osteoarthritis. Osteoarthritis and Cartilage 2009;17: S153.

Dieppe 1980 \{published data only\}

* Dieppe P A, Sathapatayavongs B, Jones H E. Intraarticular steroids in osteoarthritis. Rheumatology and Rehabilitation 1980;19(4):212-7.

Di Sante 2012 \{published data only\}

* Di Sante L, Paoloni M, Dimaggio M, Colella L, Cerino A, Bernetti A, et al. Ultrasound-guided aspiration and corticosteroid injection compared to horizontal therapy for treatment of knee osteoarthritis complicated with Baker's cyst: a randomized controlled trial. European Journal of Physical \& Rehabilitation Medicine 2012;48(4):561-7.

Fri as 2004 \{published data only\}

* Fri as G, Caracuel M A, Escudero A, Rumbao J, Pe - rez-Gujo V, Carmen Castro M, et al. Assessment of the efficacy of joint lavage versus joint lavage plus corticoids in patients with osteoarthritis of the knee. Current Medical Research and Opinion 2004;20(6):861-7.

Friedman 1980 \{published data only\}

* Friedman D M, Moore M E. The efficacy of intraarticular steroids in osteoarthritis: A double-blind study. Journal of Rheumatology 1980;7(6):850-6. 
Gaffney 1995 \{published data only\}

* Gaffney K, Ledingham J, Perry J D. Intra-articular triamcinolone hexacetonide in knee osteoarthritis: Factors influencing the clinical response. Annals of the Rheumatic Diseases 1995;54(5):379-81.

Grecomoro 1992 \{published data only\}

* Grecomoro G, Piccione F, Letizia G. Therapeutic synergism between hyaluronic acid and dexamethasone in the intra-articular treatment of osteoarthritis of the knee: a preliminary open study. Current Medical Research and Opinion 1992;13(1):49-55.

Henriksen 2015 \{published data only\}

* Henriksen M, Christensen R, Klokker L, Bartholdy C, Bandak E, Ellegaard K, et al. Evaluation of the benefit of corticosteroid injection before exercise therapy in patients with osteoarthritis of the knee. A randomized clinical trial. JAMA Internal Medicine 2015;175(6):923-30. [DOI: 10.1001/jamainternmed.2015.0461]

Jones 1996 \{published data only\}

* Jones A, Doherty M. Intra-articular corticosteroids are effective in osteoarthritis but there are no clinical predictors of response. Annals of the Rheumatic Diseases 1996;55(11): 829-32.

Lyons 2005 \{published data only\}

* Lyons C, Majeed A, Banarsee R. Effectiveness of high volume intra-articular injection of cortisone and lignocaine in osteoarthritis of the knee. Pilot study. North \& West London journal of general practice: NWLJGP 2005;11(1): 23-8.

\section{Miller 1958 \{published data only\}}

* Miller J H, White J, Norton T H. The value of intraarticular injections in osteoarthritis of the knee. Journal of Bone \& Joint Surgery - British Volume 1958;40-B(4):636-43.

NCT00414427 \{published data only\}

* NCT00414427. Using ultrasound to predict response to intraarticular corticosteroids in knee osteoarthritis. ClinicalTrials.gov (acessed 19 October 2015).

Ozturk 2006 \{published data only\}

* Ozturk C, Atamaz F, Hepguler S, Argin M, Arkun R. The safety and efficacy of intraarticular hyaluronan with/ without corticosteroid in knee osteoarthritis: 1-year, singleblind, randomized study. Rheumatology International 2006; 26(4):314-9.

Petrella 2015 \{published data only\}

Petrella R J, Eamans P, Alleyne J, Maroney M. A prospective, multi-center, randomized, double-blind feasibility study to evaluate the safety and performance of hydros joint therapy and hydros-ta joint therapy for management of pain associated with osteoarthritis in the knee. Osteoarthritis and Cartilage 2012;20:S172-3.

* Petrella R J, Emans P J, Alleyne J, Dellaert F, Gill D P, Maroney M. Safety and performance of Hydros and Hydros-TA for knee osteoarthritis. A prospective, multicenter, randomized, double-blind feasibility trial. BMC Musculoskeletal Disorders 2015;16:57:1-9.
Popov 1989 \{published data only\}

* Popov V V, Bunchuk N V, Apenysheva N P. Treatment of patients with gonarthrosis by intra-articular administration of drugs. Klinicheskaia Meditsina (Moskva) 1989;67(4): 104-8.

Ravaud 1999 \{published data only\}

* Ravaud P, Moulinier L, Giraudeau B, Ayral X, Guerin C, Noel E, et al. Effects of joint lavage and steroid injection in patients with osteoarthritis of the knee: results of a multicenter, randomized, controlled trial. Arthritis \& Rheumatology 1999;42(3):475-82.

Raynauld 2003 \{published data only\}

* Raynauld J P, Buckland-Wright C, Ward R, Choquette D, Haraoui B, Martel-Pelletier J, et al. Safety and efficacy of long-term intraarticular steroid injections in osteoarthritis of the knee: a randomized, double-blind, placebo-controlled trial. [Erratum appears in Arthritis \& Rheumatology 2003 Nov;48(11):3300]. Arthritis \& Rheumatology 2003;48(2): $370-7$.

Schue 2011 \{published data only\}

* Schue J R. Treatment of knee osteoarthritis with intraarticular infliximab may improve knee function and reduce synovial infiltration by macrophages: Proceedings of the ACR 2011 Conference. American College of Theumatology. 2011.

Smith 2003 \{published data only\}

* Smith M D, Wetherall M, Darby T, Esterman A, Slavotinek J, Roberts-Thomson P, et al. A randomized placebo-controlled trial of artroscopic lavage versus lavage plus intra-articular corticosteroids in the management of symptomatic osteoarthritis of the knee. Rheumatology 2003; 42(12):1477-85.

Smith M, Wetherall M, Roberts-Thomson P, Ahem M. Is intra-articular depot corticosteroid treatment effective in symptomatic osteoarthritis of the knee joint? [abstract]. Australian and New Zealand Journal of Medicine 2000;30 (4):527.

Wright 1960 \{published data only\} Wright V, Chandler G N, Morison R A, Hartfall S J. Intra-articular therapy in osteo-arthritis; comparison of hydrocortisone acetate and hydrocortisone tertiarybutylacetate. Annals of the Rheumatic Diseases 1960;19: 257-61.

Yavuz 2012 \{published data only\}

* Yavuz U, Sokucu S, Albayrak A, Ozturk K. Efficacy comparisons of the intraarticular steroidal agents in the patients with knee osteoarthritis. Rheumatology International 2012;32(11):3391-6.

Young 2001 \{published data only\}

* Young L, Katrib A, Cuello C, Vollmer-Conna U, Bertouch J V, Roberts-Thomson P J, et al. Effects of intraarticular glucocorticoids on macrophage infiltration and mediators of joint damage in osteoarthritis synovial membranes: findings in a double-blind, placebo-controlled study. Arthritis o Rheumatism 2001;44(2):343-50. 
Zhilyayev 2012 \{published data only\}

* Zhilyayev E, Zagrebneva A, Glazunov A, Glazunov P, Alkhimenko T. Efficacy of intraarticular and periarticular glucocorticoid injections in patients with knee osteoarthritis: A randomized double-blind study. International Journal of Rheumatic Diseases 2012;15:95.

\section{References to studies excluded from this review}

\section{Abdulla 2013 \{published data only\}}

Abdulla A, Adams N, Bone M, Elliott A M, Gaffin J, Jones $\mathrm{D}$, et al. Guidance on the management of pain in older people. Age and Ageing 2013;42 Suppl 1:i1-57.

Anonymous 1978 \{published data only\}

Anonymous. Intra-articular steroids. British Medical Journal 1978;1:600-1.

Anonymous 2011 \{published data only\} Anonymous. Knee osteoarthritis. [Original report in American Family Physician. 2011 Jun 1;83(11):1287-92; PMID: 21661710]. American Family Physician 2011;83: 1294.

Arroll 2004 \{published data only\} Arroll B, Goodyear-Smith F. Corticosteroid injections for osteoarthritis of the knee: meta-analysis. BMJ 2004;328: 869.

Arroll 2005 \{published data only\}

Arroll B, Goodyear-Smith F, Shoor S. Review: Intraarticular corticosteroid injections are better than placebo for improving symptoms of knee osteoarthritis. Evidence-Based Medicine 2005; 10:23.

Avouac 2010 \{published data only\}

Avouac J, Vicaut E, Bardin T, Richette P. Efficacy of joint lavage in knee osteoarthritis: Meta-analysis of randomized controlled studies. Rheumatology 2010;49:334-40.

Baker 1969 \{published data only\} Baker D M, Burland W L. Intra-articular injection of corticosteroid for degenerative arthritis. Practitioner 1969; 202:431-2.

Bannuru 2013 \{published data only\} Bannuru R R, McAlindon T E, Wong J B, Kent D, Schmid C. Comparative effectiveness of pharmacological interventions for knee osteoarthritis: A network metaanalysis. Arthritis and Rheumatism 2013;65:S915-6.

Bannuru 2014 \{published data only\}

Bannuru R R, Schmid C H, Sullivan M C, Kent D M, Wong J B, McAlindon T E. Differential response of placebo treatments in osteoarthritis trials: A systematic review and network meta-analysis. Osteoarthritis and Cartilage 2014; 22:S24-5.

Bannuru 2015 \{published data only\} Bannuru R R, Schmid C H, Kent D M, Vaysbrot E E, Wong J B, McAlindon T E. Comparative effectiveness of pharmacologic interventions for knee osteoarthritis: A systematic review and network meta-analysis. Annals of Internal Medicine 2015;162:46-54.
Baratham 2010 \{published data only\}

Baratham A, Lukert B P, Lindsley H B. Effects of intraarticular (IA) corticosteroid injections on bone markers and endogenous cortisol in patients with knee osteoarthritis (OA), a pilot study. Arthritis and Rheumatism 2010;62:943.

Bellamy 2005 \{published data only\}

Bellamy N, Campbell J, Robinson V, Gee T, Bourne $\mathrm{R}$, Wells $\mathrm{G}$. Intraarticular corticosteroid for treatment of osteoarthritis of the knee. Cochrane Database of Systematic Reviews 2005, Issue 2. [DOI: 10.1002/ 14651858.CD005328.pub2]

Bellamy 2006 \{published data only\}

Bellamy N, Campbell J, Robinson V, Gee T, Bourne $\mathrm{R}$, Wells G. Intraarticular corticosteroid for treatment of osteoarthritis of the knee. Cochrane Database of Systematic Reviews 2006, Issue 2. [: DOI: 10.1002/ 14651858.CD005328.pub2]

Bennell 2012 \{published data only\} Bennell K L, Hunter D J, Hinman R S. Management of osteoarthritis of the knee. BMJ (Online) 2012;345:1-8.

Bjordal 2007 \{published data only\} Bjordal J M, Klovning A, Ljunggren A E, Slordal L. Shortterm efficacy of pharmacotherapeutic interventions in osteoarthritic knee pain: A meta-analysis of randomised placebo-controlled trials. European Journal of Pain 2007;11: 125-38.

Blanke 2008 \{published data only\}

Blanke M, Gusinde J, Dobre A, Brem M H. Treatment of knee osteoarthritis. MMW Fortschritte der Medizin 2008; 150:26-9; quiz 30.

Bourne 1985 \{published data only\} Bourne I H. Injecting painful knees with triamcinolone. Practitioner 1985;229:33-4.

Brys 2004 \{published data only\}

Brys D A. Corticosteroid compared with hyaluronic acid injections for the treatment of osteoarthritis of the knee. Journal of Bone \& Joint Surgery - American Volume 2004;86A:874; author reply 874-5.

Canillas 2011 \{published data only\}

Canillas M, Kandavanam R, Reilly K. Do intra-articular (IA) steroid injections relieve pain and improve outcomes beyond two weeks for patients with osteoarthritis (OA) of the knee. Journal - Oklahoma State Medical Association 2011;104:262-3.

Cats 1979b \{published data only\} Cats A, JA I J, Davinova Y, Werthauer-Rodrigues Pereira M, Blakemore C B, Steiner F J. The efficacy of intra-articularly administered MYC 2095, triamcinolone hexacetonide and placebo in gonarthritis. A combined double-blind clinical trial. Scandinavian Journal of Rheumatology 1979;8: 199-203.

Charalambous 2004 \{published data only\} Charalambous C P. Corticosteroid compared with hyaluronic acid injections for the treatment of osteoarthritis of the knee. Journal of Bone \& Joint Surgery - American Volume 2004;86-A:874; author reply 874. 
Cheng 2012 \{published data only\}

Cheng O T, Souzdalnitski D, Vrooman B, Cheng J. Evidence-based knee injections for the management of arthritis. Pain Medicine (United States) 2012;13:740-53.

Courtney 2009 \{published data only\} Courtney P, Doherty M. Editorial: Intra-articular corticosteroid injection for osteoarthritis. International Journal of Clinical Rheumatology 2009;4:621-5.

Douglas 2012 \{published data only\}

Douglas R J. Corticosteroid injection into the osteoarthritic knee: drug selection, dose, and injection frequency. International Journal of Clinical Practice 2012;66:699-704.

Gait 2014 \{published data only\} Gait A D, Hodgson R, Cootes T F, Marjanovic E J, Parkes M, O’Neill T W, et al. Late synovial enhancement detects effects of intraarticular steroids on synovitis better than synovial volume. Osteoarthritis and Cartilage 2014;22: S240-1.

\section{Garg 2013 \{published data only\}}

Garg N, Deodhar A. A systematic review of comparative efficacy of various corticosteroid preparations for intraarticular and soft tissue injections. Annals of the Rheumatic Diseases 2013;72:A720.

Garg 2014 \{published data only\}

Garg N, Perry L, Deodhar A. Intra-articular and soft tissue injections, a systematic review of relative efficacy of various corticosteroids.. Clinical Rheumatology 2014;33:1695-706.

Gerlag 2008a \{published data only\}

Gerlag D M, Tak P P. Prolonged effect of intra-articularly administered corticosteroids in combination with arthroscopic lavage in patients with an inflammatory arthritis of the knee [Verlenging van het effect van intra-articulair toegediende corticosteroiden door combinatie hiervan met artroscopische lavage bij patienten met een inflammatoire artritis van de knie]. Nederlands Tijdschrift Voor Geneeskunde 2008;152:1953-5.

Godwin 2004 \{published data only\} Godwin M, Dawes M. Intra-articular steroid injections for painful knees. Systematic review with meta-analysis. Canadian Family Physician 2004;50:241-8.

Habib 2009 \{published data only\}

Habib G S. Systemic effects of intra-articular corticosteroids. Clinical Rheumatology 2009;28:749-56.

Habib 2010 \{published data only\}

Habib G S, Saliba W, Nashashibi M. Local effects of intraarticular corticosteroids. Clinical Rheumatology 2010;29: $347-56$.

Hepper 2009 \{published data only\}

Hepper C T, Halvorson J J, Duncan S T, Gregory A J M, Dunn W R, Spindler K P. The efficacy and duration of intraarticular corticosteroid injection for knee osteoarthritis: A systematic review of level I studies. Journal of the American Academy of Orthopaedic Surgeons 2009;17:638-46.
Hirsch 2013 \{published data only\}

Hirsch G, Kitas G, Klocke R. Intra-articular corticosteroid injection in osteoarthritis of the knee and hip: factors predicting pain relief--a systematic review. Seminars in Arthritis \& Rheumatism 2013;42:451-73.

Ivanov 1981 \{published data only\}

Ivanov B A, Koliago S A. Use of hydrocortisone in treating arthrosis deformans of the extremities. Voenno-Meditsinskii Zhurnal 1981, (6):56-7.

Jarner 1992 \{published data only\}

Jarner D, Aaboe T, Andersen L A. Intra-articular indomethacin versus triamcinolone hexacetonide injections in osteoarthritis and hydrarthrosis. Scandinavian Journal of Rheumatology. Supplement 1992;93:67.

Jones 1993 \{published data only\} Jones A, Regan M, Ledingham J, Pattrick M, Manhire A, Doherty M. Importance of placement of intra-articular steroid injections. BMJ 1993;307:1329-30.

Jones 2014 \{published data only\} Jones T, Kelsberg G, Safranek S. FPIN's clinical inquiries: Intra-articular corticosteroid injections for osteoarthritis of the knee. American Family Physician 2014;90:115-6.

Keagy 1967 \{published data only\}

Keagy R D, Keim H A. Intra-articular steroid therapy: repeated use in patients with chronic arthritis. American Journal of the Medical Sciences 1967;253:45-51.

Khitrov 1997 \{published data only\} Khitrov N A, Sil'vestrov V P, Tsurko V V. A comparative evaluation of local therapy methods in treating osteoarthrosis deformans. Terapevticheskii Arkhiv 1997;69:53-4.

Kizilkaya 2004 \{published data only\} Kizilkaya M, Yildirim O S, Dogan N, Kursad H, Okur A. Analgesic effects of intraarticular sufentanil and sufentanil plus methylprednisolone after arthroscopic knee surgery. Anesthesia and Analgesia 2004;98(4):1062-5.

Kizilkaya 2005 \{published data only\} Kizilkaya M, Yildirim O S, Ezirmik N, Kursad H, Karsan O. Comparisons of analgesic effects of different doses of morphine and morphine plus methylprednisolone after knee surgery. European Journal of Anaesthesiology 2005;22 (8):603-8.

Koyonos 2009 \{published data only\}

Koyonos L, Yanke A B, McNickle A G, Kirk S S, Kang R W, Lewis $\mathrm{P} \mathrm{B}$, et al. A randomized, prospective, double-blind study to investigate the effectiveness of adding DepoMedrol to a local anesthetic injection in postmeniscectomy patients with osteoarthritis of the knee. American Journal of Sports Medicine 2009;37(6):1077-82.

Krause 1971 \{published data only\} Krause W. Intra-articular steroid therapy in knee joint diseases. Medizinische Welt 1971;46:1841-5.

Legre-Boyer 2015 \{published data only\}

Legre-Boyer V. Viscosupplementation: Techniques, indications, results.. Orthop Traumatol Surg Res 2015;9: S101-108. 
Lequesne 1970 \{published data only\}

Lequesne M, Bensasson M, Kemmer C, Amouroux J. Painful juxtameniscal areas in certain arthropathies of the knee and their treatment by juxtameniscal cortisone infiltration. Annals of the Rheumatic Diseases 1970;29:689.

Maricar 2013 \{published data only\} Maricar N, Parkes M J, Callaghan M J, Felson D T, O’Neill $\mathrm{T} \mathrm{W}$. A systematic review of where and how to inject in the knee?. Osteoarthritis and Cartilage 2013;21:S300.

Maricar 2013c \{published data only\} Maricar N, Callaghan M J, Felson D T, O’Neill T W. Predictors of response to intra-articular steroid injections in knee osteoarthritis-a systematic review. Rheumatology (United Kingdom) 2013;52:1022-32.

Maricar 2014 \{published data only\} Maricar N, Parkes M J, Forsythe L M, Felson D T, O'Neill T W. Do psychological factors predict response to intraarticular steroid therapy in knee osteoarthritis?. Osteoarthritis and Cartilage 2014;22:S381.

McAlindon 2014 \{published data only\} McAlindon T E, Bannuru R R, Sullivan M C, Arden N $\mathrm{K}$, Berenbaum F, Bierma-Zeinstra S M, et al. OARSI guidelines for the non-surgical management of knee osteoarthritis. Osteoarthritis and Cartilage 2014;22:363-88.

Murdoch 1959 \{published data only\} Murdoch W R, Will G. Prednisolone trimethylacetate in intra-articular therapy. British Medical Journal 1959;1: 1267-70.

Murdoch 1959a \{published data only\} Murdoch W R, Will G. Synovial fluid changes in intraarticular therapy: effect of prednisolone trimethylacetate. British Medical Journal 1959;1:1271-4.

Neame 2003 \{published data only\}

Neame R L, Doherty M. Managing osteoarthritis. Practitioner 2003;247:768-70, 773, 775.

Nicol 1972 \{published data only\}

Nicol W J, Sarkin T L. Indications for intra-articular steroid in osteo-arthritis of the knee. South African Medical Journal. Suid-Afrikaanse Tydskrif Vir Geneeskunde 1972;46:379.

No named author \{published data only\} Steroid injections effective for knee osteoarthritis. Journal of Family Practice 2004;53:606.

No named author a \{published data only\} Intraarticular injections in gonarthrosis [Intraartikulare injektionen bei gonarthrose]. Pharma-Kritik 2006;28:1-2.

No named author b \{published data only\} Intra-articular injections for osteoarthritis of the knee. Medical Letter on Drugs and Therapeutics 2006;48:25-7.

No named author c \{published data only\} Corticosteroids for knee OA. Pharmaceutical Journal 2004; 272:465.

Parmigiani 2010 \{published data only\} Parmigiani L, Furtado R N V, Lopes R V, Ribeiro L H $\mathrm{C}$, Natour J. Joint lavage associated with triamcinolone hexacetonide injection in knee osteoarthritis: A randomized double-blind controlled study. Clinical Rheumatology 2010; 29:1311-5.

Pendleton 2008 \{published data only\}

Pendleton A, Millar A, O'Kane D, Wright G D, Taggart A $\mathrm{J}$. Can sonography be used to predict the response to intraarticular corticosteroid injection in primary osteoarthritis of the knee?. Scandinavian Journal of Rheumatology 2008;37: 395-7.

Punzi 2001 \{published data only\}

Punzi L. Intra-articular sodium hyaluronate reduces pain and improves function in osteoarthritis of knee. Clinical and Experimental Rheumatology 2001;19:9-10.

Rasmussen 1998 \{published data only\}

Rasmussen S, Larsen A S, Thomsen S T, Kehlet H. Intraarticular glucocorticoid reduces pain, inflammatory response and convalescence after arthroscopic meniscectomy [abstract]. Acta Orthopaedica Scandinavica 1998;69(Suppl 282):53-4.

Rasmussen 1998a \{published data only\}

Rasmussen S, Larsen A S, Thomsen S T, Kehlet H. Intraarticular glucocorticoid, morphine and bupivacaine reduces pain, inflammatory response and convalescence after arthroscopic meniscectomy [abstract]. Acta Orthopaedica Scandinavica 1998;69(Suppl 280):45.

Rasmussen 1998b \{published data only\}

Rasmussen S, Larsen A S, Thomsen S T, Kehlet H. Intra-articular glucocorticoid, bupivacaine and morphine reduces pain, inflammatory response and convalescence after arthroscopic meniscectomy [abstract]. Pain 1998;78: $131-4$.

Reshetov 2000 \{published data only\} Reshetov P P, Tverdokhleb I P, Bezmenov V A. The use of hydrocortisone combined with ultrasound with gonarthrosis patients. Voprosy Kurortologii, Fizioterapii, i Lechebnoi Fizicheskoi Kultury 2000, (4):47-8.

Ronchetti 2001 \{published data only\}

Ronchetti I P, Guerra D, Taparelli F, Boraldi F, Bergamini G, Mori G, et al. Morphological analysis of knee synovial membrane biopsies from a randomized controlled clinical study comparing the effects of sodium hyaluronate (Hyalgan) and methylprednisolone acetate (Depomedrol) in osteoarthritis. Rheumatology 2001;40:158-69.

Roskos 2005 \{published data only\}

Roskos S E. Intra-articular corticosteroid for treating osteoarthritis of the knee. American Family Physician 2005; 72:1222-3.

Saito 1971 \{published data only\}

Saito H, Asai H, Nakamura R. Effect of intra-articular injection of steroid in deforming arthrosis of the knee. Seikei Geka - Orthopedic Surgery 1971;22:612-4.

Shah 1967 \{published data only\}

Shah K D, Wright V. Intra-articular hydrocortisone in osteo-arthrosis. Annals of the Rheumatic Diseases 1967;26: 316-8. 
Sheldon 1973 \{published data only\}

Sheldon P, Beer T C. Synovitis of the knee treated by intraarticular hydrocortisone acetate, hydrocortisone acetate plus saline, or saline alone. A double-blind trial. Rheumatology and Rehabilitation 1973;12:37-41.

Stein 1996 \{published data only\}

Stein A, Helmke K, Szopko C, Stein C, Yassouridis A. Intraarticular morphine versus steroid application in gonarthrosis and arthritis in case of acute painful joint [Intraartikulare morphin - versus steroidapplikation bei gonarthrose und arthritis im akut schmerzhaften gelenk]. Deutsche Medizinische Wochenschrift 1996;121:255.

Stitik 2006 \{published data only\} Stitik T P, Kumar A, Foye P M. Corticosteroid injections for osteoarthritis. American Journal of Physical Medicine \& Rehabilitation 2006;85:S51-65; quiz S66.

Stojanovic 1969 \{published data only\}

Stojanovic I, Spasojevic L, Koturovic L, Josipovic D. Our results in treatment of gonarthrosis. Reumatizam 1969;16: 65-9.

Talke 1986 \{published data only\}

Talke M. Intra-articular corticoid therapy with triamcinolone hexacetonide. Fortschritte der Medizin 1986; 104:742-4.

Van Middelkoop 2013 \{published data only\} Van Middelkoop M, Dziedzic K S, Doherty M, Zhang W, Bijlsma J W, McAlindon T E, et al. Individual patient data meta-analysis of trials investigating the effectiveness of intra-articular glucocorticoid injections in patients with knee or hip osteoarthritis: an OA Trial Bank protocol for a systematic review. Systems Review 2013;2:54.

Van Middelkoop 2013a \{published data only\} Van Middelkoop M, Dziedzic K, Doherty M, Zhang W, Bijlsma J W, McAlindon T, et al. The OA trial bank: Individual patient data meta-analysis of trials investigating the effectiveness of intra-articular corticosteroid injections in patients with knee or hip oa. Annals of the Rheumatic Diseases. 2013; Vol. 72.

Van Middelkoop 2013b \{published data only\} Van Middelkoop M, Dziedzic K, Doherty M, Zhang W, Bijlsma J, McAlindon T, et al. The oa trial bank: Individual patient data meta-analysis of trials investigating the effectiveness of intra-articular corticosteroid injections in patients with knee or hip oa. Osteoarthritis and Cartilage 2013;21:S259.

Van Middelkoop 2014 \{published data only\} Van Middelkoop M, Arden N, Atchia I, Birrell F, Chao J, Lambert R, et al. The OA trial bank: Meta-analysis of individual patient data show that patients with severe pain or with inflammatory signs detected by ultrasound especially benefit from intra-articular glucocorticoids for knee or hip OA. Annals of the Rheumatic Diseases 2014;73:749.

Van Middelkoop 2014a \{published data only\} Van Middelkoop M, Arden N, Atchia I, Birrell F, Chao J, Lambert R G, et al. The OA trial bank: Meta-analysis of individual patient data show that patients with severe pain or with inflammatory signs detected by ultrasound especially benefit from intra-articular glucocorticoids for knee or hip OA. Osteoarthritis and Cartilage 2014;22:S474-5.

Wang 1998 \{published data only\}

Wang J J, Ho S T, Lee S C, Tang J J S, Liaw W J.

Intraarticular triamcinolone acetonide for pain control after arthroscopic knee surgery. Anesthesia and Analgesia 1998;87 (5):1113-6.

Wang 2015 \{published data only\}

Wang F, He X. Intra-articular hyaluronic acid and corticosteroids in the treatment of knee osteoarthritis: A meta-analysis. Experimental and Therapeutic Medicine 2015; 9:493-500.

Wramner 1959 \{published data only\}

Wramner T. The effect of intra-articular hydrocortisone therapy upon the joint temperature in osteoarthritis and rheumatoid arthritis. Acta Rheumatologica Scandinavica 1959;5:59-65.

Yamamoto 1970 \{published data only\}

Yamamoto M, Fukuma H. Intra-articular injection of adrenocortical steroid hormone in osteoarthritis of the knee. Seikei Geka - Orthopedic Surgery 1970;21:103-6.

Zhang 2008 \{published data only\} Zhang W, Moskowitz R W, Nuki G, Abramson S, Altman $\mathrm{R} \mathrm{D}$, Arden N, et al. OARSI recommendations for the management of hip and knee osteoarthritis, Part II: OARSI evidence-based, expert consensus guidelines. Osteoarthritis and Cartilage 2008;16:137-62.

Zhang 2010 \{published data only\} Zhang W, Nuki G, Moskowitz R W, Abramson S, Altman $\mathrm{R} \mathrm{D}$, Arden N K, et al. OARSI recommendations for the management of hip and knee osteoarthritis: part III: Changes in evidence following systematic cumulative update of research published through January 2009. Osteoarthritis Cartilage 2010;18:476-99.

Zuckner 1958 \{published data only\} Zuckner J, Machek O. Intra-articular injections of hydrocortisone, prednisolone, and their tertiary-butylacetate derivatives in patients with rheumatoid arthritis and osteoarthritis. Journal of Chronic Diseases 1958;8:637-44.

\section{References to studies awaiting assessment}

Ellis 2011 \{published data only\}

Ellis M E, Lun V M Y, Preston Wiley J. Combination treatment for knee osteoarthritis. Clinical Journal of Sport Medicine 2011;21(4):374-5.

Friedman 1978 \{published data only\} Friedman D M, Moore M F. The efficacy of intraarticular corticosteroid for osteoarthritis of the knee. Arthritis and Rheumatism 1978;21:556.

Hall 2013 \{published data only\}

Hall M, Courtney P, Doherty S, Latief K, Zhang W, Doherty M. Ultrasound response following intra-articular corticosteroid and a placebo injection in symptomatic 
osteoarthritic knees: A pilot study. Annals of the Rheumatic Diseases 2013;72:54.

\section{Hall 2014 \{published data only\}}

Hall M, Doherty S, Courtney P, Latief K, Zhang W, Doherty M. Ultrasound detected synovial change and pain response following intra-articular injection of corticosteroid and a placebo in symptomatic osteoarthritic knees: A pilot study. Annals of the Rheumatic Diseases 2014;73:1590-1.

Motyl 2013 \{published data only\}

Motyl J M, Driban J B, McAdams E, McAlindon T E. Reliability and sensitivity of the 20-meter walk test among patients with knee osteoarthritis. Osteoarthritis and Cartilage 2013;21:S137.

\section{Motyl 2013a \{published data only\}}

Motyl J M, Driban J B, McAdams E, Price L L, McAlindon T E. Test-retest reliability and sensitivity of the 20-meter walk test among patients with knee osteoarthritis. $B M C$ Musculoskeletal Disorders 2013;14:166.

O’Neill 2014 \{published data only\}

O’Neill T W, Parkes M J, Maricar N, Gait A D, Cootes T F, Marjanovic $\mathrm{E} J$, et al. Bone marrow lesions may not respond to anti-inflammatory treatments in knee osteoarthritis (OA). Osteoarthritis and Cartilage 2014;22:S475.

Raynauld 1999 \{published data only\}

Raynauld J P. Clinical trials: Impact of intraarticular steroid injections on the progression of knee osteoarthritis. Osteoarthritis and Cartilage 1999;7:348-9.

Rezende 2012 \{published data only\}

Rezende M U, Campos G C, Pailo A F, Frucchi R, Pasqualim T. Evaluation of the effect of adding corticosteroid to viscosupplementation: A prospective and randomized study. Osteoporosis International 2012;23:S132-3.

Singh 1996 \{published data only\}

Singh G K, Jain S, Das S K, Sharma V. Conservative treatment of osteoarthritis $(\mathrm{OA})$ of the knee vs add on intraarticular (IA) steroid injection [abstract]. Journal of Clinical Epidemiology 1996;49 Suppl 1:8s.

\section{Additional references}

\section{Altman 1996}

Altman R, Brandt K, Hochberg M, Moskowitz R, Bellamy $\mathrm{N}$, Bloch DA, et al. Design and conduct of clinical trials in patients with osteoarthritis: recommendations from a task force of the Osteoarthritis Research Society. Results from a workshop. Osteoarthritis and Cartilage 1996;4(4):217-43.

\section{Bellamy 1995}

Bellamy N. Outcome measurement in osteoarthritis clinical trials. The Journal of Rheumatology. Supplement 1995;43: 49-51.

Brandt 1996

Brandt KD. Diagnosis and Nonsurgical Management of Osteoarthritis. 1st Edition. Caddo, OK: Professional Communications, Inc., 1996.

\section{Brandt 2001}

Brandt K D. Management of osteoarthritis. In: Ruddy S, Harris E D Jr, Sledge C B editor(s). Kelley's Textbook of Rheumatology. 6th Edition. Philadelphia: W. B. Saunders Company, 2001:1419-32.

Clegg 2006

Clegg DO, Reda DJ, Harris CL, Klein MA, O’Dell JR, Hooper MM, et al. Glucosamine, chondroitin sulfate, and the two in combination for painful knee osteoarthritis. The New England Journal of Medicine 2006;354(8):795-808.

Cohen 1988

Cohen J. Statistical Power Analysis for the Behavioral Sciences. 2nd Edition. Hillsdale, NJ: Lawrence Earlbaum Associates, 1988

Creamer 1997

Creamer P. Intra-articular corticosteroid injections in osteoarthritis: do they work and if so, how?. Annals of the Rheumatic Diseases 1997;56(11):634-6.

da Costa 2012

da Costa B R, Nüesch E, Reichenbach S, Jüni P, Rutjes A W S. Doxycycline for osteoarthritis of the knee or hip. Cochrane Database of Systematic Reviews 2012, Issue 11. [DOI: 10.1002/14651858.CD007323.pub3]

\section{da Costa 2012a}

da Costa BR, Rutjes AWS, Johnston BC, Reichenbach S, Nüesch E, Tonia T, et al. Methods to convert continuous outcomes into odds ratios of treatment response and numbers needed to treat: meta-epidemiological study. International Journal of Epidemiology 2012;41(5):1445-59.

\section{da Costa 2013}

da Costa BR, Nüesch E, Rutjes AW, Johnston BC, Reichenbach $S$, Trelle $S$, et al. Combining follow-up and change data is valid in meta-analyses of continuous outcomes: a meta-epidemiological study. Journal of Clinical Epidemiology 2013;66(8):847-55.

\section{da Costa 2014}

da Costa BR, Nüesch E, Kasteler R, Husni E, Welch $\mathrm{V}$, Rutjes AW, et al. Oral or transdermal opioids for osteoarthritis of the knee or hip. Cochrane Database of Systematic Reviews 2014, Issue 9. [DOI: 10.1002/ 14651858.CD003115.pub4]

da Costa 2014a

da Costa BR, Jüni P. Systematic reviews and meta-analyses of randomized trials: principles and pitfalls. European Heart Journal 2014;35:3336-45.

DerSimonian 1986

DerSimonian R, Laird N. Meta-analysis in clinical trials. Controlled Clinical Trials 1986;7(3):177-88.

Dickersin 1994

Dickersin K, Scherer R, Lefebvre C. Identifying relevant studies for systematic reviews. BMJ 1994;309(6964): 1286-91.

\section{Dworkin 2008}

Dworkin RH, Turk DC, Wyrwich KW, Beaton D, Cleeland $\mathrm{CS}$, Farrar JT, et al. Interpreting the clinical importance 
of treatment outcomes in chronic pain clinical trials: IMMPACT recommendations. Journal of Pain 2008;9: 105-21.

\section{Dworkin 2009}

Dworkin RH, Turk DC, McDermott MP, Peirce-Sandner $S$, Burke LB, Cowan P, et al. Interpreting the clinical importance of group differences in chronic pain clinical trials: IMMPACT recommendations. Pain 2009;146: $238-44$.

Egger 1997

Egger M, Davey Smith G, Schneider M, Minder C. Bias in meta-analysis detected by a simple, graphical test. $B M J$ 1997;315(7109):629-34.

Egger 2001

Egger M, Smith GD. Principles of and procedures for systematic reviews. In: Egger M, Smith GD, Altman DG editor(s). Systematic Reviews in Health Care: Meta-Analysis in Context. London: BMJ Books, 2001:23-42.

\section{Egger 2003}

Egger M, Jüni P, Bartlett C, Holenstein F, Sterne J. How important are comprehensive literature searches and the assessment of trial quality in systematic reviews? Empirical study. Health Technology Assessment (Winchester, England) 2003;7(1):1-76.

\section{Felson 2000}

Felson DT, Lawrence RC, Dieppe PA, Hirsch R, Helmick CG, Jordan JA, et al. Osteoarthritis: New insights. Part 1: The disease and its risk factors (NIH Conference). Annals of Internal Medicine 2000;133(8):635-46.

\section{Felson 2000a}

Felson DT, Lawrence RC, Hochberg MC, McAlindon T, Minor MA, Blair SN, et al. Osteoarthritis: New insights. Part 2: Treatment approaches (NIH Conference). Annals of Internal Medicine 2000;133(9):726-37.

\section{Guyatt 2008}

Guyatt G, Oxman AD, Vist GE, Kunz R, Falck-Ytter Y, Alonso-Coello P, et al. GRADE: an emerging consensus on rating quality of evidence and strength of recommendations. BMJ 2008;336(7650):924-6.

Gøtzsche 2007

Gøtzsche PC, Hróbjartsson A, Maric K, Tendal B. Data extraction errors in meta-analyses that use standardized mean differences. JAMA 2007;298(4):430-7.

\section{Higgins 2003}

Higgins JP, Thompson SG, Deeks JJ, Altman DG. Measuring inconsistency in meta-analyses. BMJ 2003;327 (7414):557-60.

\section{Higgins 2011}

Higgins JP, Altman DG, Gøtzsche PC, Jüni P, Moher D, Oxman AD, et al. The Cochrane Collaboration's tool for assessing risk of bias in randomised trials. BMJ 2011;343: $1-9$.

Hochberg 2012

Hochberg MC, Altman RD, April KT, Benkhalti M, Guyatt G, McGowan J, et al. American College of Rheumatology
2012 Recommendations for the Use of Nonpharmacologic and Pharmacologic Therapies in Osteoarthritis of the Hand, Hip, and Knee. Arthritis Care and Research 2012;64(4): 465-74.

Jüni 2001

Jüni P, Altman DG, Egger M. Systematic reviews in health care: Assessing the quality of controlled clinical trials. BMJ 2001;323(7303):42-6.

\section{Jüni 2006}

Jüni P, Reichenbach S, Dieppe P. Osteoarthritis: rational approach to treating the individual. Best Practice \& Research. Clinical Rheumatology 2006;20(4):721-40.

\section{Lefebvre 2008}

Lefebvre C, Eisinga A, McDonald S, Paul N. Enhancing access to reports of randomized trials published world-wide-the contribution of EMBASE records to the Cochrane Central Register of Controlled Trials (CENTRAL) in The Cochrane Library. Emerging Themes in Epidemiology 2008; 5(13):1-13.

\section{McColl 2000}

McColl GJ, Dolezal H, Eizenberg N. Common corticosteroid injections. An anatomical and evidence based review. Australian Family Physician 2000;29:922-6.

\section{Nüesch 2009}

Nüesch E, Trelle S, Reichenbach S, Rutjes AWS, Bürgi E, Scherer M, et al. The effects of the exclusion of patients from the analysis in randomised controlled trials: metaepidemiological study. BMJ 2009;339:b3244.

\section{Nüesch 2010}

Nüesch E, Trelle S, Reichenbach S, Rutjes AW, Tschannen B, Altman DG, et al. Small study effects in meta-analyses of osteoarthritis trials: meta-epidemiological study. BMJ 2010;341:c3515.

\section{Nüesch 2013}

Nüesch E, Häuser W, Bernardy K, Barth J, Jüni P. Comparative efficacy of pharmacological and nonpharmacological interventions in fibromyalgia syndrome: network meta-analysis. Annals of the Rheumatic Diseases 2013;72(6):955-62.

\section{Peters 2008}

Peters JL, Sutton AJ, Jones DR, Abrams KR, Rushton L. Contour-enhanced meta-analysis funnel plots help distinguish publication bias from other causes of asymmetry. Journal of Clinical Epidemiology 2008;61(10):991-6.

\section{Pham 2004}

Pham T, van der Heijde D, Altman RD, Anderson JJ, Bellamy N, Hochberg M, et al. OMERACT-OARSI initiative: Osteoarthritis Research Society International set of responder criteria for osteoarthritis clinical trials revisited. Osteoarthritis and Cartilage 2004;12(5):389-99.

\section{Reichenbach 2007}

Reichenbach S, Sterchi R, Scherer M, Trelle S, Burgi E, Burgi U, et al. Meta-analysis: chondroitin for osteoarthritis of the knee or hip. Annals of Internal Medicine 2007;146 (8):580-90. 


\section{Reichenbach 2010}

Reichenbach S, Rutjes AW, Nüesch E, Trelle S, Jüni P. Joint lavage for osteoarthritis of the knee. Cochrane Database of Systematic Reviews 2010, Issue 5. [DOI: 10.1002/ 14651858.CD007320.pub2]

RevMan 2014

The Nordic Cochrane Centre, The Cochrane Collaboration. Review Manager (RevMan). 5.3. Copenhagen: The Nordic Cochrane Centre, The Cochrane Collaboration, 2014.

\section{Rozental 2000}

Rozental TD, Sculco TP. Intra-articular corticosteroids: an updated overview. American Journal of Orthopedics 2000;29 (1):18-23

\section{Rucker 2008}

Rucker G, Schwarzer G, Carpenter JR, Schumacher M. Undue reliance on $\mathrm{I}(2)$ in assessing heterogeneity may mislead. BMC Medical Research Methodology 2008;8(1):79.

\section{Rutjes 2009}

Rutjes AW, Nüesch E, Sterchi R, Kalichman L, Hendriks E, Osiri M, et al. Transcutaneous electrostimulation for osteoarthritis of the knee. Cochrane Database of Systematic Reviews 2009, Issue 4. [DOI: 10.1002/ 14651858.CD002823.pub2]
Rutjes 2009a

Rutjes AW, Nuesch E, Reichenbach S, Jüni P. S-

Adenosylmethionine for osteoarthritis of the knee or hip. Cochrane Database of Systematic Reviews 2009, Issue 4. [DOI: 10.1002/14651858.CD007321.pub2]

Rutjes 2010

Rutjes AW, Nuesch E, Sterchi R, Jüni P. Therapeutic ultrasound for osteoarthritis of the knee or hip. Cochrane Database of Systematic Reviews 2010, Issue 1. [DOI: 10.1002/14651858.CD003132.pub2]

\section{Sterne 2001}

Sterne JA, Egger M. Funnel plots for detecting bias in metaanalysis: guidelines on choice of axis. Journal of Clinical Epidemiology 2001;54(10):1046-55.

\section{Sterne 2011}

Sterne JA, Sutton AJ, Ioannidis JP, Terrin N, Jones DR, Lau $\mathrm{J}$, et al. Recommendations for examining and interpreting funnel plot asymmetry in meta-analyses of randomised controlled trials. BMJ 2011;343:d4002.

\section{Thompson 1999}

Thompson SG, Sharp SJ. Explaining heterogeneity in metaanalysis: a comparison of methods. Statistics in Medicine 1999;18(20):2693-708.

* Indicates the major publication for the study 


\section{CHARACTERISTICS OF STUDIES}

\section{Characteristics of included studies [ordered by study ID]}

\section{Beyaz 2012}

\begin{tabular}{ll}
\hline Methods & $\begin{array}{l}\text { Randomised controlled trial } \\
\text { 3-arm parallel-group design } \\
\text { Trial duration: } 12 \text { weeks }\end{array}$ \\
\hline Participants & $\begin{array}{l}82 \text { participants with knee osteoarthritis were randomised } \\
73 \text { participants were reported at baseline } \\
\text { Number of females: } 59 \text { of } 73 \text { (81\%) } \\
\text { Mean age: } 69.1 \text { years }\end{array}$ \\
\hline Interventions & $\begin{array}{l}\text { Experimental intervention } \\
40 \text { mg triamcinolone acetonide (1 ml) plus } 20 \text { mg bupivacaine (4 ml), single intra- } \\
\text { articular injection } \\
\text { Control intervention } \\
1 \text { ml saline plus } 20 \text { mg bupivacaine (4 ml), single intra-articular injection }\end{array}$ \\
\hline Outcomes & $\begin{array}{l}\text { Extracted pain outcome: WOMAC pain } \\
\text { Extracted function outcome: WOMAC function } \\
\text { Maximum follow-up: } 12 \text { weeks }\end{array}$ \\
\hline Notes & Funding: Boztepe State Hospital, Ordu, Republic of Turkey \\
\hline
\end{tabular}

Risk of bias

\begin{tabular}{|c|c|c|}
\hline Bias & Authors' judgement & Support for judgement \\
\hline $\begin{array}{l}\text { Random sequence generation (selection } \\
\text { bias) }\end{array}$ & Unclear risk & $\begin{array}{l}\text { Quote: "Patients were randomized by } \\
\text { the closed-envelope technique into three } \\
\text { groups". Because the "closed-envelope } \\
\text { technique" was not further specified, the } \\
\text { risk of selection bias was considered unclear }\end{array}$ \\
\hline Allocation concealment (selection bias) & Unclear risk & $\begin{array}{l}\text { Quote: "Patients were randomized by } \\
\text { the closed-envelope technique into three } \\
\text { groups". Because the "closed-envelope } \\
\text { technique" was not further specified, the } \\
\text { risk of selection bias was considered unclear }\end{array}$ \\
\hline Blinding of participants? & Low risk & $\begin{array}{l}\text { Quote: "Since the solutions were in differ- } \\
\text { ent colors, sticker was used to cover injec- } \\
\text { tors to hide to ensure blinding." }\end{array}$ \\
\hline Blinding of health care provider(s) & Low risk & $\begin{array}{l}\text { Quote: "Injections were administered by } \\
\text { another blinded investigator." }\end{array}$ \\
\hline
\end{tabular}


Beyaz 2012 (Continued)

\begin{tabular}{|c|c|c|}
\hline Intention-to-treat analysis performed? Pain & High risk & $\begin{array}{l}9 \text { out of } 82 \text { participants were excluded be- } \\
\text { cause (quote) "they did not come for fol- } \\
\text { low-up" }\end{array}$ \\
\hline $\begin{array}{l}\text { Intention-to-treat analysis performed? } \\
\text { Function }\end{array}$ & High risk & $\begin{array}{l}9 \text { out of } 82 \text { participants were excluded be- } \\
\text { cause (quote) "they did not come for fol- } \\
\text { low-up" }\end{array}$ \\
\hline
\end{tabular}

Campos 2013

\begin{tabular}{ll} 
Methods & $\begin{array}{l}\text { Randomised controlled trial } \\
\text { 2-arm parallel-group design } \\
\text { Trial duration: } 24 \text { weeks }\end{array}$ \\
\hline Participants & $\begin{array}{l}104 \text { participants with knee osteoarthritis were randomised } \\
104 \text { participants were reported at baseline } \\
\text { Number of females: } 79 \text { out of } 104 \text { (76\%) } \\
\text { Mean age: } 63.0 \text { years }\end{array}$ \\
\hline Interventions & $\begin{array}{l}\text { Experimental intervention } \\
20 \text { mg triamcinolone hexacetonide (1 ml) plus } 6 \text { ml hylan GF-20, single intra-articular } \\
\text { injection } \\
\text { Control intervention } \\
6 \text { ml hylan GF-20 intra-articularly, single intra-articular injection } \\
\text { Quote: "Patients with bilateral disease had both knees treated with the same drug, but } \\
\text { only one knee (reported by the patient as the worst) was included in the study" }\end{array}$ \\
\hline Outcomes & $\begin{array}{l}\text { Extracted pain outcome: WOMAC Pain } \\
\text { Extracted function outcome: WOMAC Global } \\
\text { Maximum follow-up: } 24 \text { weeks }\end{array}$ \\
\hline Notes & Funding: São Paulo Research Foundation (FAPESP) (Sao Paulo, Brazil) \\
\hline
\end{tabular}

\section{Risk of bias}

\begin{tabular}{|c|c|c|}
\hline Bias & Authors' judgement & Support for judgement \\
\hline $\begin{array}{l}\text { Random sequence generation (selection } \\
\text { bias) }\end{array}$ & Low risk & $\begin{array}{l}\text { Quote: "Randomization was performed by } \\
\text { a computer-generated program (available } \\
\text { at: http://www.randomization.com/)." }\end{array}$ \\
\hline Allocation concealment (selection bias) & Unclear risk & $\begin{array}{l}\text { Method used to conceal the random se- } \\
\text { quence of allocation was not reported, so } \\
\text { the risk of selection bias was unclear }\end{array}$ \\
\hline Blinding of participants? & Low risk & $\begin{array}{l}\text { Quote: "Patients were blinded (blocked } \\
\text { from watching the procedures by the use of }\end{array}$ \\
\hline
\end{tabular}

Intra-articular corticosteroid for knee osteoarthritis (Review) 
Campos 2013 (Continued)

\begin{tabular}{|c|c|c|}
\hline & & $\begin{array}{l}\text { a windscreen sunshade and did not know } \\
\text { to which group they were assigned)." }\end{array}$ \\
\hline Blinding of health care provider(s) & Unclear risk & $\begin{array}{l}\text { Physicians were not explicitly described as } \\
\text { blinded, so the risk of performance bias was } \\
\text { unclear }\end{array}$ \\
\hline Intention-to-treat analysis performed? Pain & High risk & $\begin{array}{l}5 \text { of } 52 \text { participants excluded in experimen- } \\
\text { tal group, } 6 \text { of } 52 \text { participants excluded in } \\
\text { control group }\end{array}$ \\
\hline $\begin{array}{l}\text { Intention-to-treat analysis performed? } \\
\text { Function }\end{array}$ & High risk & $\begin{array}{l}5 \text { of } 52 \text { participants excluded in experimen- } \\
\text { tal group, } 6 \text { of } 52 \text { participants excluded in } \\
\text { control group }\end{array}$ \\
\hline
\end{tabular}

Castro 2007

\begin{tabular}{|c|c|}
\hline Methods & $\begin{array}{l}\text { Randomised controlled trial } \\
\text { 5-arm parallel-group design } \\
\text { Trial duration: } 12.9 \text { months }\end{array}$ \\
\hline Participants & $\begin{array}{l}150 \text { participants with knee osteoarthritis were randomised } \\
\text { Unclear number of participants with knee osteoarthritis reported at baseline } \\
\text { Number of females: } 115 \\
\text { Mean age: } 65.4\end{array}$ \\
\hline Interventions & $\begin{array}{l}\text { Experimental intervention } \\
\text { Triamcinolone acetonide (no dosage or unit specified) + joint lavage, single intra-articular } \\
\text { application } \\
\text { Control intervention } \\
\text { Joint lavage, single intra-articular application }\end{array}$ \\
\hline Outcomes & $\begin{array}{l}\text { Extracted pain outcome: WOMAC Pain } \\
\text { Extracted function outcome: WOMAC Function } \\
\text { Maximum follow-up: } 12.9 \text { months }\end{array}$ \\
\hline Notes & \\
\hline
\end{tabular}

\section{Risk of bias}

\begin{tabular}{l|l|l}
\hline Bias & Authors' judgement & Support for judgement \\
\hline $\begin{array}{l}\text { Random sequence generation (selection } \\
\text { bias) }\end{array}$ & Unclear risk & $\begin{array}{l}\text { Method used to generate random sequence } \\
\text { of allocation was not reported, so the risk } \\
\text { of selection bias was unclear }\end{array}$ \\
\hline Allocation concealment (selection bias) & Unclear risk & $\begin{array}{l}\text { Method used to conceal the random se- } \\
\text { quence of allocation was not reported, so }\end{array}$
\end{tabular}

Intra-articular corticosteroid for knee osteoarthritis (Review) 
Castro 2007 (Continued)

\begin{tabular}{|c|c|c|}
\hline & & the risk of selection bias was unclear \\
\hline Blinding of participants? & Unclear risk & $\begin{array}{l}\text { It was unclear if method used to blind par- } \\
\text { ticipants was appropriate }\end{array}$ \\
\hline Blinding of health care provider(s) & Unclear risk & $\begin{array}{l}\text { Physicians were not explicitly described as } \\
\text { blinded, so the risk of performance bias was } \\
\text { unclear }\end{array}$ \\
\hline Intention-to-treat analysis performed? Pain & Low risk & $\begin{array}{l}\text { All randomised participants included in the } \\
\text { analysis }\end{array}$ \\
\hline $\begin{array}{l}\text { Intention-to-treat analysis performed? } \\
\text { Function }\end{array}$ & Low risk & $\begin{array}{l}\text { All randomised participants included in the } \\
\text { analysis }\end{array}$ \\
\hline
\end{tabular}

\section{Cederlof 1966}

\begin{tabular}{ll}
\hline Methods & $\begin{array}{l}\text { Randomised controlled trial } \\
\text { 2-arm parallel-group design } \\
\text { Trial duration: } 8 \text { weeks }\end{array}$ \\
\hline Participants & $\begin{array}{l}51 \text { injections in } 44 \text { knees belonging to } 44 \text { participants with knee osteoarthritis were } \\
\text { randomised } \\
\text { Unclear number of participants reported at baseline } \\
\text { Number of females: } 41 \text { of } 44 \text { (93.2\%) } \\
\text { Mean age: Not reported }\end{array}$ \\
\hline Interventions & $\begin{array}{l}\text { Experimental intervention } \\
50 \text { mg prednisolone acetate (2 ml), single intra-articular injection } \\
\text { Control intervention } \\
2 \text { ml physiologic saline, single intra-articular injection }\end{array}$ \\
\hline Outcomes & Extracted pain outcome: Patient global assessment \\
\hline Notes & Funding: Aktiebolaget Ferrosan, Malmö, Sweden \\
\hline
\end{tabular}

\section{Risk of bias}

\begin{tabular}{lll}
\hline Bias & Authors' judgement & Support for judgement \\
\hline $\begin{array}{l}\text { Random sequence generation (selection } \\
\text { bias) }\end{array}$ & Low risk & $\begin{array}{l}\text { Quote: “The out-patient department nurse } \\
\text { decided which fluid was to be injected by } \\
\text { tossing a coin” }\end{array}$ \\
\hline Allocation concealment (selection bias) & Unclear risk & $\begin{array}{l}\text { Method used to conceal the random se- } \\
\text { quence of allocation was not reported, so } \\
\text { the risk of selection bias was unclear }\end{array}$
\end{tabular}




\section{Cederlof 1966 (Continued)}

\begin{tabular}{|c|c|c|}
\hline Blinding of participants? & Unclear risk & $\begin{array}{l}\text { It was unclear if method used to blind par- } \\
\text { ticipants was appropriate }\end{array}$ \\
\hline Blinding of health care provider(s) & Unclear risk & $\begin{array}{l}\text { Physicians were not explicitly described as } \\
\text { blinded, so the risk of performance bias was } \\
\text { unclear }\end{array}$ \\
\hline Intention-to-treat analysis performed? Pain & Low risk & $\begin{array}{l}\text { All randomised participants included in the } \\
\text { analysis }\end{array}$ \\
\hline $\begin{array}{l}\text { Intention-to-treat analysis performed? } \\
\text { Function }\end{array}$ & Unclear risk & $\begin{array}{l}\text { Did not report extractable function out- } \\
\text { come data }\end{array}$ \\
\hline
\end{tabular}

Chao 2010

\begin{tabular}{ll}
\hline Methods & $\begin{array}{l}\text { Randomised controlled trial } \\
\text { 2-arm parallel-group design } \\
\text { Trial duration: } 12 \text { weeks }\end{array}$ \\
\hline Participants & 79 participants with knee osteoarthritis were randomised \\
& 79 participants were reported at baseline \\
& Number of females: 2 of 79 (2.5\%) \\
& Mean age: 64.3 years \\
\hline Interventions & $\begin{array}{l}\text { Experimental intervention } \\
40 \text { mg triamcinolone acetonide (1 ml), single intra-articular injection } \\
\text { Control intervention } \\
1 \text { ml } 0.9 \% \text { saline, single intra-articular injection }\end{array}$ \\
\hline Outcomes & Extracted pain outcome: WOMAC Pain \\
& Extracted function outcome: WOMAC Global \\
& Maximum follow-up: 12 weeks \\
\hline Notes & Funding: National Skeletal Muscle Research Center, NIH Grant HD050837 \\
\hline
\end{tabular}

\section{Risk of bias}

\begin{tabular}{|c|c|c|}
\hline Bias & Authors' judgement & Support for judgement \\
\hline $\begin{array}{l}\text { Random sequence generation (selection } \\
\text { bias) }\end{array}$ & Unclear risk & $\begin{array}{l}\text { Method used to generate random sequence } \\
\text { of allocation was not reported, so the risk } \\
\text { of selection bias was unclear }\end{array}$ \\
\hline Allocation concealment (selection bias) & Unclear risk & $\begin{array}{l}\text { Method used to conceal the random se- } \\
\text { quence of allocation was not reported, so } \\
\text { the risk of selection bias was unclear }\end{array}$ \\
\hline
\end{tabular}


Chao 2010 (Continued)

\begin{tabular}{|c|c|c|}
\hline Blinding of participants? & Low risk & $\begin{array}{l}\text { Quote: "Patients and assessors were blinded } \\
\text { to treatment status" "Patients were then } \\
\text { randomized to receive an injection of either } \\
\text { (...) triamcinolone acetonide or (...) saline, } \\
\text { which were drawn into a syringe covered } \\
\text { with opaque tape prior to the patient en- } \\
\text { counter." }\end{array}$ \\
\hline Blinding of health care provider(s) & High risk & $\begin{array}{l}\text { Quote: "Injections were given (...) by a } \\
\text { non-blinded physician" }\end{array}$ \\
\hline Intention-to-treat analysis performed? Pain & High risk & $\begin{array}{l}9 \text { of } 40 \text { participants excluded in experimen- } \\
\text { tal group, } 9 \text { of } 39 \text { participants excluded in } \\
\text { control group }\end{array}$ \\
\hline $\begin{array}{l}\text { Intention-to-treat analysis performed? } \\
\text { Function }\end{array}$ & High risk & $\begin{array}{l}9 \text { of } 40 \text { participants excluded in experimen- } \\
\text { tal group, } 9 \text { of } 39 \text { participants excluded in } \\
\text { control group }\end{array}$ \\
\hline
\end{tabular}

Di Sante 2012

\begin{tabular}{|c|c|}
\hline Methods & $\begin{array}{l}\text { Randomised controlled trial } \\
\text { 3-arm parallel-group design } \\
\text { Trial duration: } 4 \text { weeks }\end{array}$ \\
\hline Participants & $\begin{array}{l}60 \text { participants with knee osteoarthritis were randomised } \\
60 \text { participants were reported at baseline } \\
\text { Mean age: } 70.6\end{array}$ \\
\hline Interventions & $\begin{array}{l}\text { Experimental interventions } \\
40 \mathrm{mg} \text { methylprednisolone acetate and lidocaine hydrochloride, single intra-articular } \\
\text { injection + Horizontal therapy* locally ( } 10 \text { times over } 2 \text { weeks, each lasting } 30 \text { minutes) } \\
\text { Control intervention } \\
\text { Horizontal therapy* locally ( } 10 \text { times over } 2 \text { weeks, each lasting } 30 \text { minutes) } \\
\text { Treatment duration: } 4 \text { weeks } \\
\text { *Horizontal therapy was described as (quote): "Placement of } 4 \text { cutaneous electrodal pads } \\
\text { ( } 8 \text { x } 13 \mathrm{~cm}) \text {, one in center of the popliteal, one on the patella and two others at the } \\
\text { posterior proximal site of the thighs, with a stimulation frequency oscillating at } 100 \mathrm{~Hz} \\
\text { between } 4400 \text { and } 12346 \mathrm{~Hz} \text { for } 30 \text { minutes" } \\
\text { Maximum follow-up: } 4 \text { weeks }\end{array}$ \\
\hline Outcomes & $\begin{array}{l}\text { Extracted pain outcome: Pain overall } \\
\text { Extracted function outcome: WOMAC Function } \\
\text { Maximum follow-up: } 4 \text { weeks }\end{array}$ \\
\hline Notes & \\
\hline
\end{tabular}

Risk of bias

Intra-articular corticosteroid for knee osteoarthritis (Review)

Copyright () 2015 The Cochrane Collaboration. Published by John Wiley \& Sons, Ltd. 
Di Sante 2012 (Continued)

\begin{tabular}{|c|c|c|}
\hline Bias & Authors' judgement & Support for judgement \\
\hline $\begin{array}{l}\text { Random sequence generation (selection } \\
\text { bias) }\end{array}$ & Low risk & $\begin{array}{l}\text { Quote: “(..) using a computer generated } 1: \\
1: 1 \text { allocation sequence." }\end{array}$ \\
\hline Allocation concealment (selection bias) & Unclear risk & $\begin{array}{l}\text { Method used to conceal the random se- } \\
\text { quence of allocation was not reported, so } \\
\text { the risk of selection bias was unclear }\end{array}$ \\
\hline Blinding of participants? & High risk & $\begin{array}{l}\text { No intra-articular sham injection in the } \\
\text { placebo group (local therapy only) }\end{array}$ \\
\hline Blinding of health care provider(s) & High risk & $\begin{array}{l}\text { No intra-articular sham injection in the } \\
\text { placebo group (local therapy only) }\end{array}$ \\
\hline Intention-to-treat analysis performed? Pain & Low risk & $\begin{array}{l}\text { All randomised participants included in the } \\
\text { analysis }\end{array}$ \\
\hline $\begin{array}{l}\text { Intention-to-treat analysis performed? } \\
\text { Function }\end{array}$ & Low risk & $\begin{array}{l}\text { All randomised participants included in the } \\
\text { analysis }\end{array}$ \\
\hline
\end{tabular}

\section{Dieppe 1980}

\begin{tabular}{|c|c|}
\hline Methods & $\begin{array}{l}\text { Randomised controlled trial } \\
\text { 2-arm cross-over design } \\
\text { Trial duration: } 2 \text { weeks }\end{array}$ \\
\hline Participants & $\begin{array}{l}24 \text { knees belonging to } 16 \text { participants with knee osteoarthritis were randomised } \\
24 \text { knees belonging to } 16 \text { participants were reported at baseline } \\
\text { Mean age: } 65 \\
\text { Number of females: } 13 \text { out of } 16(81 \%)\end{array}$ \\
\hline Interventions & $\begin{array}{l}\text { Experimental intervention } \\
20 \mathrm{mg} \text { triamcinalone hexacetonide }(1 \mathrm{ml}) \text {, single intra-articular injection } \\
\text { Control intervention } \\
1 \mathrm{ml} \text { of saline, single intra-articular injection } \\
\text { Cross-over after } 1 \text { week. Every participant received } 1 \text { injection (experimental and control) } \\
\text { each }\end{array}$ \\
\hline Outcomes & $\begin{array}{l}\text { Extracted pain outcome: Pain overall } \\
\text { Maximum follow-up: } 1 \text { week }\end{array}$ \\
\hline Notes & $\begin{array}{l}2 \text { trials were reported in the same paper. Trial A did not report pain outcomes seperately } \\
\text { for treatment and intervention and was excluded. Trial B was included in the analysis }\end{array}$ \\
\hline
\end{tabular}

\section{Risk of bias}




\section{Dieppe 1980 (Continued)}

\begin{tabular}{|c|c|c|}
\hline Bias & Authors' judgement & Support for judgement \\
\hline $\begin{array}{l}\text { Random sequence generation (selection } \\
\text { bias) }\end{array}$ & Unclear risk & $\begin{array}{l}\text { Method used to generate random sequence } \\
\text { of allocation was not reported, so the risk } \\
\text { of selection bias was unclear }\end{array}$ \\
\hline Allocation concealment (selection bias) & Unclear risk & $\begin{array}{l}\text { Method used to conceal the random se- } \\
\text { quence of allocation was not reported, so } \\
\text { the risk of selection bias was unclear }\end{array}$ \\
\hline Blinding of participants? & High risk & $\begin{array}{l}\text { Quote: Described as "single-blind, blind- } \\
\text { observer", implying that participants were } \\
\text { not blinded }\end{array}$ \\
\hline Blinding of health care provider(s) & High risk & $\begin{array}{l}\text { Quote: Described } \\
\text { as "single-blind, blind-observer", implying } \\
\text { that healthcare providers were not blinded }\end{array}$ \\
\hline Intention-to-treat analysis performed? Pain & Low risk & $\begin{array}{l}\text { All randomised participants included in the } \\
\text { analysis }\end{array}$ \\
\hline $\begin{array}{l}\text { Intention-to-treat analysis performed? } \\
\text { Function }\end{array}$ & Unclear risk & $\begin{array}{l}\text { Not applicable, no function outcome re- } \\
\text { ported }\end{array}$ \\
\hline
\end{tabular}

Friedman 1980

\begin{tabular}{l|l}
\hline Methods & $\begin{array}{l}\text { Randomised controlled trial } \\
\text { 2-arm parallel-group design } \\
\text { Trial duration: } 8 \text { weeks }\end{array}$ \\
\hline Participants & $\begin{array}{l}34 \text { participants with knee osteoarthritis were randomised } \\
34 \text { participants were reported at baseline } \\
\text { Number of females: Not reported } \\
\text { Mean age: } 60.0 \text { years }\end{array}$ \\
\hline Interventions & $\begin{array}{l}\text { Experimental intervention } \\
20 \text { mg triamcinolone hexacetonide, single intra-articular injection } \\
\text { Control intervention } \\
\text { "Polysorbate, sorbitol solution, benzyl alcohol and water", single intra-articular injection }\end{array}$ \\
\hline Outcomes & $\begin{array}{l}\text { Extracted pain outcome: Pain overall } \\
\text { Maximum follow-up: } 8 \text { weeks }\end{array}$ \\
\hline Notes & $\begin{array}{l}\text { Funding: Grant from the Eastern Pennsylvania Chapter of the Arthritis Foundation and } \\
\text { by the Philadelphia Foundation }\end{array}$ \\
\hline
\end{tabular}

\section{Risk of bias}


Friedman 1980 (Continued)

\begin{tabular}{|c|c|c|}
\hline Bias & Authors' judgement & Support for judgement \\
\hline $\begin{array}{l}\text { Random sequence generation (selection } \\
\text { bias) }\end{array}$ & Unclear risk & $\begin{array}{l}\text { Method used to generate random sequence } \\
\text { of allocation was not clearly reported, so the } \\
\text { risk of selection bias was unclear. Quote: } \\
\text { "Half of the patients, selected according } \\
\text { to a predetermined random schedule, were } \\
\text { treated (...)." }\end{array}$ \\
\hline
\end{tabular}

Allocation concealment (selection bias) Unclear risk

Blinding of participants?

Low risk

Blinding of health care provider(s) Low risk
Method used to conceal the random sequence of allocation was not reported, so the risk of selection bias was unclear

Quote: "During the time of [the injection] (...), the physician and patient were positioned so that neither could see the nurse's face nor the material she injected. Thus, neither had any direct information concerning what was injected and, practically speaking, had no contact with the only person who knew"

Quote: “The physician-experimenter performed the arthrocentesis (...) a nurse-assistant entered the room and performed the injection through the intraarticular needle, and left the room. During the time of this taking place, the physician and patient were positioned so that neither could see the nurse's face nor the material she injected. Thus, neither had any direct information concerning what was injected and, practically speaking, had no contact with the only person who knew"

Intention-to-treat analysis performed? Pain Low risk

Intention-to-treat analysis performed? Unclear risk Function
All randomised participants included in the analysis. Quote: "All patients were seen 1 $\mathrm{wk}, 4 \mathrm{wk}, 6 \mathrm{wk}$ and $8 \mathrm{wk}$ post-injection except those whose pain scores at any subsequent evaluation were the same as their pretreatment scores; they were not seen further. It was assumed that their scores would no longer improve and they were counted as remaining at their pre-treatment level throughout the experiment"

Not applicable, no function outcome reported 
Fri as 2004

\begin{tabular}{|c|c|}
\hline Methods & $\begin{array}{l}\text { Randomised controlled trial } \\
\text { 2-arm parallel-group design } \\
\text { Trial duration: } 12 \text { weeks }\end{array}$ \\
\hline Participants & $\begin{array}{l}299 \text { knees belonging to } 205 \text { participants with knee osteoarthritis were randomised } \\
299 \text { knees belonging to } 205 \text { participants were reported at baseline } \\
\text { Number of females: } 234 \text { ( } 78 \% \text { ) of } 299 \text { knees belonged to female participants } \\
\text { Mean age: } 67.0 \text { years }\end{array}$ \\
\hline Interventions & $\begin{array}{l}\text { Experimental intervention } \\
40 \mathrm{mg} \text { triamcinolone acetonide plus lavage }\left(3 \mathrm{~L} \text { of cold }\left(8^{\circ} \mathrm{C}\right) \text { saline }\right) \text {, single intra-articular } \\
\text { application } \\
\text { Control intervention } \\
\text { Lavage }\left(3 \mathrm{~L} \text { of cold }\left(8^{\circ} \mathrm{C}\right) \text { saline), single intra-articular application }\right.\end{array}$ \\
\hline Outcomes & $\begin{array}{l}\text { Extracted pain outcome: Pain overall } \\
\text { Maximum follow-up: } 12 \text { weeks }\end{array}$ \\
\hline Notes & \\
\hline
\end{tabular}

Risk of bias

\begin{tabular}{|c|c|c|}
\hline Bias & Authors' judgement & Support for judgement \\
\hline $\begin{array}{l}\text { Random sequence generation (selection } \\
\text { bias) }\end{array}$ & Unclear risk & $\begin{array}{l}\text { Method used to generate random sequence } \\
\text { of allocation was not reported, so the risk } \\
\text { of selection bias was unclear }\end{array}$ \\
\hline Allocation concealment (selection bias) & Unclear risk & $\begin{array}{l}\text { Method used to conceal the random se- } \\
\text { quence of allocation was not reported, so } \\
\text { the risk of selection bias was unclear }\end{array}$ \\
\hline Blinding of participants? & Unclear risk & $\begin{array}{l}\text { Although the authors stated "Glucocor- } \\
\text { ticoid treatment with triamcinolone ace- } \\
\text { tonide was always given on a blind basis", } \\
\text { they also stated that this was an open trial } \\
\text { (Quote: "The study was of the longitudi- } \\
\text { nal, open, prospective, controlled type"). } \\
\text { The risk of performance bias was therefore } \\
\text { considered unclear }\end{array}$ \\
\hline Blinding of health care provider(s) & Unclear risk & $\begin{array}{l}\text { Although the authors stated "Glucocor- } \\
\text { ticoid treatment with triamcinolone ace- } \\
\text { tonide was always given on a blind basis", } \\
\text { they also stated that this was an open trial } \\
\text { (Quote: "The study was of the longitudi- } \\
\text { nal, open, prospective, controlled type"). } \\
\text { The risk of performance bias was therefore } \\
\text { considered unclear }\end{array}$ \\
\hline
\end{tabular}


Fri as 2004 (Continued)

\begin{tabular}{|c|c|c|}
\hline Intention-to-treat analysis performed? Pain & High risk & $\begin{array}{l}82 \text { of } 299 \text { knees were excluded at } 1 \text { month, } \\
51 \text { of } 299 \text { knees were excluded at } 3 \text { months }\end{array}$ \\
\hline $\begin{array}{l}\text { Intention-to-treat analysis performed? } \\
\text { Function }\end{array}$ & Unclear risk & $\begin{array}{l}\text { Not applicable, no function outcome re- } \\
\text { ported }\end{array}$ \\
\hline
\end{tabular}

Gaffney 1995

\begin{tabular}{|c|c|c|}
\hline Methods & \multicolumn{2}{|c|}{$\begin{array}{l}\text { Randomised controlled trial } \\
\text { 2-arm parallel-group design } \\
\text { Trial duration: } 6 \text { weeks }\end{array}$} \\
\hline Participants & \multicolumn{2}{|c|}{$\begin{array}{l}84 \text { participants with knee osteoarthritis were randomised } \\
84 \text { participants were reported at baseline } \\
\text { Number of females: } 60 \text { out of } 84(71 \%) \\
\text { Mean age: } 67.0 \text { years }\end{array}$} \\
\hline Interventions & \multicolumn{2}{|c|}{$\begin{array}{l}\text { Experimental intervention } \\
20 \mathrm{mg} \text { triamcinolone hexacetonide }(1 \mathrm{ml}) \text {, single intra-articular injection } \\
\text { Control intervention } \\
1 \mathrm{ml} \text { of } 0.9 \% \text { normal saline, single intra-articular injection }\end{array}$} \\
\hline Outcomes & \multicolumn{2}{|c|}{$\begin{array}{l}\text { Extracted pain outcome: Pain overall } \\
\text { Extracted function outcome: Other function composite } \\
\text { Maximum follow-up: } 6 \text { weeks }\end{array}$} \\
\hline \multicolumn{3}{|l|}{ Notes } \\
\hline \multicolumn{3}{|l|}{ Risk of bias } \\
\hline Bias & Authors' judgement & Support for judgement \\
\hline $\begin{array}{l}\text { Random sequence generation (selection } \\
\text { bias) }\end{array}$ & Unclear risk & $\begin{array}{l}\text { Method used to generate random sequence } \\
\text { of allocation was not reported, so the risk } \\
\text { of selection bias was unclear }\end{array}$ \\
\hline Allocation concealment (selection bias) & Unclear risk & $\begin{array}{l}\text { Method used to conceal the random se- } \\
\text { quence of allocation was not reported, so } \\
\text { the risk of selection bias was unclear }\end{array}$ \\
\hline Blinding of participants? & Low risk & $\begin{array}{l}\text { Quote: "Although this study was not, by } \\
\text { strict definition, double-blinded, we at- } \\
\text { tempted to ensure that patients were not } \\
\text { aware of the treatment allocated to them, } \\
\text { by shielding the identity of the treatment } \\
\text { received from their view at the time of in- } \\
\text { jection; only the injecting physician (IL) } \\
\text { was aware of the nature of the injection ad- }\end{array}$ \\
\hline
\end{tabular}

Intra-articular corticosteroid for knee osteoarthritis (Review) 
Gaffney 1995 (Continued)

ministered.”

Blinding of health care provider(s) High risk

Quote: "Although this study was not, by strict definition, double-blinded, we attempted to ensure that patients were not aware of the treatment allocated to them, by shielding the identity of the treatment received from their view at the time of injection; only the injecting physician (IL) was aware of the nature of the injection administered."

Intention-to-treat analysis performed? Pain Unclear risk

2 of 42 participants in control group withdrew. It was unclear whether all participants randomised were also analysed

Intention-to-treat analysis performed? Unclear risk Function

2 of 42 participants in control group withdrew. It was unclear whether all participants randomised were also analysed

\section{Grecomoro 1992}

\begin{tabular}{l|l}
\hline Methods & $\begin{array}{l}\text { Randomised controlled trial } \\
\text { 2-arm cross-over design } \\
\text { Trial duration: } 8.6 \text { weeks }\end{array}$ \\
\hline Participants & $\begin{array}{l}40 \text { participants with knee osteoarthritis were randomised } \\
40 \text { participants were reported at baseline } \\
\text { Number of females: } 27 \text { out of } 40 \text { (67.5\%) } \\
\text { Mean age: } 42.3 \text { years }\end{array}$ \\
\hline Interventions & $\begin{array}{l}\text { Experimental intervention } \\
0.4 \text { mg dexamethasonephosphate plus } 20 \text { mg sodium hyaluronate in } 2 \text { ml phosphate } \\
\text { buffer, } 5 \text { intra-articular injections, } 1 \text { weekly for } 5 \text { weeks } \\
\text { Control intervention } \\
20 \text { mg sodium hyaluronate in } 2 \text { ml phosphate buffer, } 5 \text { intra-articular injections, } 1 \text { weekly } \\
\text { for } 5 \text { weeks }\end{array}$ \\
\hline Outcomes & $\begin{array}{l}\text { Extracted pain outcome: Pain on activities other than walking } \\
\text { Maximum follow-up: } 8.6 \text { weeks }\end{array}$ \\
\hline Notes & \\
\hline
\end{tabular}

Risk of bias

Bias

Authors' judgement

Support for judgement

Intra-articular corticosteroid for knee osteoarthritis (Review) 


\section{Grecomoro 1992 (Continued)}

\begin{tabular}{|c|c|c|}
\hline $\begin{array}{l}\text { Random sequence generation (selection } \\
\text { bias) }\end{array}$ & Unclear risk & $\begin{array}{l}\text { Method used to generate random sequence } \\
\text { of allocation was not reported, so the risk } \\
\text { of selection bias was unclear }\end{array}$ \\
\hline Allocation concealment (selection bias) & Unclear risk & $\begin{array}{l}\text { Method used to conceal the random se- } \\
\text { quence of allocation was not reported, so } \\
\text { the risk of selection bias was unclear }\end{array}$ \\
\hline Blinding of participants? & High risk & $\begin{array}{l}\text { Quote: "The trial design was open and ran- } \\
\text { domized." }\end{array}$ \\
\hline Blinding of health care provider(s) & High risk & $\begin{array}{l}\text { Quote: "The trial design was open and ran- } \\
\text { domized." }\end{array}$ \\
\hline Intention-to-treat analysis performed? Pain & Low risk & $\begin{array}{l}\text { All randomised participants included in the } \\
\text { analysis }\end{array}$ \\
\hline $\begin{array}{l}\text { Intention-to-treat analysis performed? } \\
\text { Function }\end{array}$ & Unclear risk & $\begin{array}{l}\text { Not applicable, no function outcome re- } \\
\text { ported }\end{array}$ \\
\hline
\end{tabular}

\section{Henriksen 2015}

\begin{tabular}{|c|c|}
\hline Methods & $\begin{array}{l}\text { Randomised controlled trial } \\
\text { 2-arm parallel-group design } \\
\text { Trial duration: } 26 \text { weeks }\end{array}$ \\
\hline Participants & $\begin{array}{l}100 \text { participants with knee osteoarthritis were randomised } \\
100 \text { participants were reported at baseline } \\
\text { Number of females: } 61 \text { out of } 100(61 \%) \\
\text { Mean age: } 63.4 \text { years }\end{array}$ \\
\hline Interventions & $\begin{array}{l}\text { Experimental intervention } \\
40 \mathrm{mg} \text { methylprednisolone acetate }(1 \mathrm{ml}) \text { dissolved in } 4 \mathrm{ml} \text { of lidocaine hydrochloride, } \\
\text { single intra-articular injection }+12 \text {-week exercise program } \\
\text { Control intervention } \\
1 \mathrm{ml} \text { isotonic saline mixed with } 4 \mathrm{ml} \text { of lidocaine hydrochloride, single intra-articular } \\
\text { injection }+12 \text {-week exercise program }\end{array}$ \\
\hline Outcomes & $\begin{array}{l}\text { Extracted pain outcome: Other pain composite } \\
\text { Extracted pain function: Other function composite } \\
\text { Maximum follow-up: } 26 \text { weeks }\end{array}$ \\
\hline Notes & $\begin{array}{l}\text { Funding: Grants by: 10-093704 from the Danish Council for Independent Research } \\
\text { Medical Science, Oak Foundation, Association of Danish Physiotherapists, Lundbeck } \\
\text { Foundation, Capital Region of Denmark }\end{array}$ \\
\hline
\end{tabular}

\section{Risk of bias}


Henriksen 2015 (Continued)

\begin{tabular}{|c|c|c|}
\hline Bias & Authors' judgement & Support for judgement \\
\hline $\begin{array}{l}\text { Random sequence generation (selection } \\
\text { bias) }\end{array}$ & Low risk & $\begin{array}{l}\text { Quote: "A computer-generated random- } \\
\text { ization sequence was produced before any } \\
\text { patients were enrolled that allocated partic- } \\
\text { ipants in permuted blocks of } 2 \text { to } 6 \text { to the } \\
\text { corticosteroid or the placebo group (1:1)." }\end{array}$ \\
\hline Allocation concealment (selection bias) & Low risk & $\begin{array}{l}\text { Quote: "The randomization sequence was } \\
\text { prepared by a biostatistician with no clini- } \\
\text { cal involvement in the trial (R.C.). The al- } \\
\text { location was concealed in a password-pro- } \\
\text { tected computer file only accessible by the } \\
\text { biostatistician. Individual allocations were } \\
\text { held in sealed, opaque, consecutively num- } \\
\text { bered envelopes." }\end{array}$ \\
\hline Blinding of participants? & Low risk & $\begin{array}{l}\text { Quote: "To ensure blinding of the partici- } \\
\text { pants and the clinician performing the in- } \\
\text { jections, the syringes were prepared by the } \\
\text { study nurse in the absence of participants } \\
\text { and blinded study staff. Because the cor- } \\
\text { ticosteroid liquid is milky white and the } \\
\text { saline is clear, the syringes were masked } \\
\text { with opaque tape to prevent disclosure of } \\
\text { the content during the injection procedure. } \\
\text { " }\end{array}$ \\
\hline Blinding of health care provider(s) & Low risk & $\begin{array}{l}\text { Quote: "To ensure blinding of the partici- } \\
\text { pants and the clinician performing the in- } \\
\text { jections, the syringes were prepared by the } \\
\text { study nurse in the absence of participants } \\
\text { and blinded study staff. Because the cor- } \\
\text { ticosteroid liquid is milky white and the } \\
\text { saline is clear, the syringes were masked } \\
\text { with opaque tape to prevent disclosure of } \\
\text { the content during the injection procedure. } \\
\text { " }\end{array}$ \\
\hline Intention-to-treat analysis performed? Pain & Low risk & $\begin{array}{l}\text { All randomised participants included in the } \\
\text { analysis }\end{array}$ \\
\hline $\begin{array}{l}\text { Intention-to-treat analysis performed? } \\
\text { Function }\end{array}$ & Low risk & $\begin{array}{l}\text { All randomised participants included in the } \\
\text { analysis }\end{array}$ \\
\hline
\end{tabular}

Intra-articular corticosteroid for knee osteoarthritis (Review) 
Jones 1996

\begin{tabular}{l|l}
\hline Methods & $\begin{array}{l}\text { Randomised controlled trial } \\
\text { 2-arm cross-over design } \\
\text { Trial duration: } 16 \text { weeks }\end{array}$ \\
\hline Participants & 59 participants with knee osteoarthritis were randomised \\
& 59 participants were reported at baseline \\
& Number of females: 37 out of 59 (63\%) \\
& Mean age: 70.6 years
\end{tabular}

\section{Risk of bias}

\begin{tabular}{|c|c|c|}
\hline Bias & Authors' judgement & Support for judgement \\
\hline $\begin{array}{l}\text { Random sequence generation (selection } \\
\text { bias) }\end{array}$ & Unclear risk & $\begin{array}{l}\text { Method used to generate random sequence } \\
\text { of allocation was not reported, so the risk } \\
\text { of selection bias was unclear }\end{array}$ \\
\hline
\end{tabular}

\begin{tabular}{|c|c|c|}
\hline Allocation concealment (selection bias) & Unclear risk & $\begin{array}{l}\text { Method used to conceal the random se- } \\
\text { quence of allocation was not reported, so } \\
\text { the risk of selection bias was unclear }\end{array}$ \\
\hline Blinding of participants? & Unclear risk & $\begin{array}{l}\text { Quote: "Each injection was given by a sec- } \\
\text { ond operator, thus blinding both patient } \\
\text { and assessor." No further description of } \\
\text { blinding }\end{array}$ \\
\hline
\end{tabular}

Blinding of health care provider(s) Unclear risk

Quote: "Each injection was given by a second operator, thus blinding both patient and assessor." No further description of blinding

Intention-to-treat analysis performed? Pain High risk

Quotes: "As some data was missing due to patient withdrawal, all analyses were performed on a last measures carried forward, intention to treat basis", but still not all participants randomised were analysed. Quote: "One patient failed to enter the 
Lyons 2005

\begin{tabular}{ll}
\hline Methods & $\begin{array}{l}\text { Randomised controlled trial } \\
\text { 2-arm parallel-group design } \\
\text { Trial duration: } 8.6 \text { weeks }\end{array}$ \\
\hline Participants & $\begin{array}{l}20 \text { participants with knee osteoarthritis were randomised } \\
\text { Unclear number of participants with knee osteoarthritis reported at baseline } \\
\text { Number of females: } 11 \\
\text { Mean age: } 59.7\end{array}$ \\
\hline Interventions & $\begin{array}{l}\text { Experimental intervention } \\
80 \text { mg methylprednisolone }(2 \text { ml })+5 \text { ml 1\% lignocaine, single intra-articular injection } \\
\text { Control intervention } \\
10 \text { ml of } 1 \% \text { lignocaine, single intra-articular injection }\end{array}$ \\
\hline Outcomes & $\begin{array}{l}\text { Extracted pain outcome: Pain overall } \\
\text { Extracted function outcome: Global disability score } \\
\text { Maximum follow-up: } 8.6 \text { weeks }\end{array}$ \\
\hline Notes & $\begin{array}{l}\text { Funding: West London Research Network, Primary Care Scientist Award funded by the } \\
\text { Department of Health }\end{array}$ \\
\hline
\end{tabular}

\section{Risk of bias}

\begin{tabular}{|c|c|c|}
\hline Bias & Authors' judgement & Support for judgement \\
\hline $\begin{array}{l}\text { Random sequence generation (selection } \\
\text { bias) }\end{array}$ & Unclear risk & $\begin{array}{l}\text { Method used to generate random sequence } \\
\text { of allocation was not reported, so the risk } \\
\text { of selection bias was unclear }\end{array}$ \\
\hline Allocation concealment (selection bias) & Unclear risk & $\begin{array}{l}\text { Method used to conceal the random se- } \\
\text { quence of allocation was not reported, so } \\
\text { the risk of selection bias was unclear }\end{array}$ \\
\hline Blinding of participants? & Unclear risk & $\begin{array}{l}\text { It was unclear if method used to blind } \\
\text { healthcare providers was appropriate }\end{array}$ \\
\hline Blinding of health care provider(s) & High risk & $\begin{array}{l}\text { Quote: "(The study) was single blind, with } \\
\text { the principal investigator administering the } \\
\text { treatment and also measuring outcome." }\end{array}$ \\
\hline
\end{tabular}


Lyons 2005 (Continued)

\begin{tabular}{|c|c|c|}
\hline Intention-to-treat analysis performed? Pain & Low risk & $\begin{array}{l}\text { All randomised participants included in the } \\
\text { analysis }\end{array}$ \\
\hline $\begin{array}{l}\text { Intention-to-treat analysis performed? } \\
\text { Function }\end{array}$ & Low risk & $\begin{array}{l}\text { All randomised participants included in the } \\
\text { analysis }\end{array}$ \\
\hline
\end{tabular}

\section{Miller 1958}

\begin{tabular}{ll} 
Methods & $\begin{array}{l}\text { Randomised controlled trial } \\
\text { 5-arm parallel-group design } \\
\text { Trial duration: } 33.8 \text { weeks }\end{array}$ \\
\hline Participants & $\begin{array}{l}202 \text { participants with knee osteoarthritis were randomised } \\
\text { Unclear number of participants reported at baseline } \\
\text { Number of females: } 122\end{array}$ \\
& Mean age: not reported \\
\hline Interventions & $\begin{array}{l}\text { Experimental intervention } \\
50 \text { mg of hydrocortisone (2 ml) }+8 \text { ml of physiological normal saline, } 5 \text { intra-articular } \\
\text { injections, interval of } 2 \text { weeks } \\
\text { Control intervention } \\
\text { Physiological normal saline solution (no dosage), } 5 \text { intra-articular injections, interval of } \\
2 \text { weeks }\end{array}$ \\
\hline Outcomes & Extracted pain outcome: Patients' global assessment \\
& Maximum follow-up: 25.8 weeks \\
\hline Notes & \\
\hline
\end{tabular}

\section{Risk of bias}

\begin{tabular}{|c|c|c|}
\hline Bias & Authors' judgement & Support for judgement \\
\hline $\begin{array}{l}\text { Random sequence generation (selection } \\
\text { bias) }\end{array}$ & Unclear risk & $\begin{array}{l}\text { Method used to generate random sequence } \\
\text { of allocation was not reported, so the risk } \\
\text { of selection bias was unclear }\end{array}$ \\
\hline Allocation concealment (selection bias) & Unclear risk & $\begin{array}{l}\text { Method used to conceal the random se- } \\
\text { quence of allocation was not reported, so } \\
\text { the risk of selection bias was unclear }\end{array}$ \\
\hline Blinding of participants? & Unclear risk & $\begin{array}{l}\text { It was unclear if method used to blind par- } \\
\text { ticipants was appropriate }\end{array}$ \\
\hline Blinding of health care provider(s) & Unclear risk & $\begin{array}{l}\text { Physicians were not explicitly described as } \\
\text { blinded, so the risk of performance bias was } \\
\text { unclear }\end{array}$ \\
\hline
\end{tabular}


Miller 1958 (Continued)

\begin{tabular}{llll}
\hline Intention-to-treat analysis performed? Pain & High risk & 21 of 202 participants were excluded \\
\hline $\begin{array}{l}\text { Intention-to-treat } \\
\text { Function }\end{array}$ & analysis performed? & Unclear risk & $\begin{array}{l}\text { Not applicable, no function outcome re- } \\
\text { ported }\end{array}$ \\
\hline
\end{tabular}

\section{NCT00414427}

\begin{tabular}{l|l}
\hline Methods & $\begin{array}{l}\text { Randomised controlled trial } \\
\text { 2-arm parallel-group design } \\
\text { Trial duration: } 12 \text { weeks }\end{array}$ \\
\hline Participants & $\begin{array}{l}79 \text { participants with knee osteoarthritis were randomised } \\
79 \text { participants were reported at baseline } \\
\text { Number of females: } 3 \text { out of } 79 \text { (4\%) } \\
\text { Mean age: } 63.0 \text { years }\end{array}$ \\
\hline Interventions & $\begin{array}{l}\text { Experimental intervention } \\
40 \text { mg triamcinolone acetonide, single intra-articular injection } \\
\text { Control intervention } \\
0.9 \% \text { saline (no dosage), single intra-articular injection }\end{array}$ \\
\hline Outcomes & $\begin{array}{l}\text { Extracted pain outcome: WOMAC Pain } \\
\text { Maximum follow-up: } 12 \text { weeks }\end{array}$ \\
\hline Notes & Funding: University of California, San Diego \\
\hline
\end{tabular}

\section{Risk of bias}

\begin{tabular}{|c|c|c|}
\hline Bias & Authors' judgement & Support for judgement \\
\hline $\begin{array}{l}\text { Random sequence generation (selection } \\
\text { bias) }\end{array}$ & Unclear risk & $\begin{array}{l}\text { Method used to generate random sequence } \\
\text { of allocation was not reported, so the risk } \\
\text { of selection bias was unclear }\end{array}$ \\
\hline Allocation concealment (selection bias) & Unclear risk & $\begin{array}{l}\text { Method used to conceal the random se- } \\
\text { quence of allocation was not reported, so } \\
\text { the risk of selection bias was unclear }\end{array}$ \\
\hline Blinding of participants? & Unclear risk & $\begin{array}{l}\text { It was unclear if method used to blind par- } \\
\text { ticipants was appropriate }\end{array}$ \\
\hline Blinding of health care provider(s) & Unclear risk & $\begin{array}{l}\text { It was unclear if method used to blind } \\
\text { healthcare providers was appropriate }\end{array}$ \\
\hline Intention-to-treat analysis performed? Pain & High risk & $\begin{array}{l}7 \text { of } 40 \text { participants excluded in experimen- } \\
\text { tal group, } 5 \text { of } 39 \text { participants excluded in } \\
\text { control group }\end{array}$ \\
\hline
\end{tabular}

Intra-articular corticosteroid for knee osteoarthritis (Review) 


\section{NCT00414427 (Continued)}

Intention-to-treat analysis performed? Unclear risk Function
Not applicable, no function outcome reported

\section{Ozturk 2006}

\begin{tabular}{l|l}
\hline Methods & $\begin{array}{l}\text { Randomised controlled trial } \\
\text { 2-arm parallel-group design } \\
\text { Trial duration: } 52 \text { weeks }\end{array}$ \\
\hline Participants & $\begin{array}{l}4 \text { participants with knee osteoarthritis were randomised } \\
40 \text { participants were reported at baseline } \\
\text { Number of females: } 39 \text { out of } 47 \text { (83\%) } \\
\text { Mean age: } 58.0 \text { years }\end{array}$ \\
\hline Interventions & $\begin{array}{l}\text { Experimental intervention } \\
40 \text { mg triamcinolone acetonide (1 ml) plus } 2 \text { ml sodium hyaluronate. Sodium } \\
\text { hyaluronate was administered in } 3 \text { intra-articular injections in the first month and } 3 \\
\text { intra-articular injections during the sixth month, triamcinolone acid was added prior to } \\
\text { the first and fourth application } \\
\text { Control intervention } \\
2 \text { ml sodium hyaluronate, } 3 \text { intra-articular injections in the first month, and } 3 \text { intra- } \\
\text { articular injections during the sixth month }\end{array}$ \\
\hline Extracted pain outcome: WOMAC Pain \\
\hline Maximum follow-up: 25.9 weeks
\end{tabular}

\section{Risk of bias}

\begin{tabular}{|c|c|c|}
\hline Bias & Authors' judgement & Support for judgement \\
\hline $\begin{array}{l}\text { Random sequence generation (selection } \\
\text { bias) }\end{array}$ & Low risk & $\begin{array}{l}\text { Quote: "Patients were assigned to one of } \\
\text { the two treatment groups based on a table } \\
\text { of randomly assorted digits: A and B." }\end{array}$ \\
\hline Allocation concealment (selection bias) & Unclear risk & $\begin{array}{l}\text { Method used to conceal the random se- } \\
\text { quence of allocation was not reported, so } \\
\text { the risk of selection bias was unclear }\end{array}$ \\
\hline Blinding of participants? & Unclear risk & $\begin{array}{l}\text { It was unclear if participants were blinded } \\
\text { (trial described as "single blind" but no de- } \\
\text { scription of who was blinded) }\end{array}$ \\
\hline Blinding of health care provider(s) & Unclear risk & $\begin{array}{l}\text { It was unclear if healthcare providers were } \\
\text { blinded (trial described as "single blind" but } \\
\text { no description of who was blinded) }\end{array}$ \\
\hline
\end{tabular}




\section{Ozturk 2006 (Continued)}

\begin{tabular}{l|l|l}
\hline $\begin{array}{l}\text { Intention-to-treat analysis performed? Pain } \\
\text { High risk }\end{array}$ & $\begin{array}{l}\text { 7 of 23 participants excluded in experimen- } \\
\text { tal group, } 0 \text { of 24 participants excluded in } \\
\text { control group }\end{array}$ \\
\hline $\begin{array}{l}\text { Intention-to-treat analysis performed? } \\
\text { Function }\end{array}$ & Unclear risk & $\begin{array}{l}\text { Not applicable, no function outcome re- } \\
\text { ported }\end{array}$ \\
\hline
\end{tabular}

\section{Petrella 2015}

Methods

Randomised controlled trial

2-arm parallel-group design

Trial duration: 26 weeks

98 participants with knee osteoarthritis were randomised
98 participants were reported at baseline
Number of females: 56 out of $98(57 \%)$
Mean age: 59.7 years

Interventions

\section{Experimental intervention}

$10 \mathrm{mg}$ triamcinolone acetonide + hyaluronan solution (no dosage stated), $6 \mathrm{ml}$ total, single intra-articular injection

Control intervention

Hyaluronan solution (no dosage stated), single intra-articular injection

\begin{tabular}{ll} 
Outcomes & $\begin{array}{l}\text { Extracted pain outcome: WOMAC Pain } \\
\text { Extracted function outcome: WOMAC Function } \\
\text { Maximum follow-up: } 26 \text { weeks }\end{array}$ \\
\hline Notes & Funding: Carbylan Therapeutics \\
\hline
\end{tabular}

\section{Risk of bias}

\begin{tabular}{|c|c|c|}
\hline Bias & Authors' judgement & Support for judgement \\
\hline $\begin{array}{l}\text { Random sequence generation (selection } \\
\text { bias) }\end{array}$ & Low risk & $\begin{array}{l}\text { Quote: "The randomization treatment was } \\
\text { computer generated and was stratified by } \\
\text { study center." }\end{array}$ \\
\hline Allocation concealment (selection bias) & Unclear risk & $\begin{array}{l}\text { Quote: "The randomization treatment was } \\
\text { computer generated and was stratified by } \\
\text { study center." }\end{array}$ \\
\hline Blinding of participants? & Unclear risk & $\begin{array}{l}\text { It was unclear if method used to blind par- } \\
\text { ticipants was appropriate }\end{array}$ \\
\hline Blinding of health care provider(s) & High risk & $\begin{array}{l}\text { Quote: "An injecting physician delivered } \\
\text { the randomized treatment and remained }\end{array}$ \\
\hline
\end{tabular}


Petrella 2015 (Continued)

unblinded."

Intention-to-treat analysis performed? Pain High risk

Intention-to-treat analysis performed? High risk

Function
2 of 33 participants excluded in experimental group, 1 of 33 participants excluded in control group

2 of 33 participants excluded in experimental group, 1 of 33 participants excluded in control group

\section{Popov 1989}

\begin{tabular}{|c|c|c|}
\hline Methods & \multicolumn{2}{|c|}{$\begin{array}{l}\text { Randomised controlled trial } \\
\text { 5-arm parallel-group design } \\
\text { Trial duration: } 2.7 \text { weeks }\end{array}$} \\
\hline Participants & \multicolumn{2}{|c|}{$\begin{array}{l}48 \text { participants with knee osteoarthritis were randomised } \\
\text { Unclear number of participants with knee osteoarthritis reported at baseline } \\
\text { Number of females: } 38 \\
\text { Mean age: } 55 \text { years }\end{array}$} \\
\hline Interventions & \multicolumn{2}{|c|}{$\begin{array}{l}\text { Experimental interventions } \\
\text { Intervention (A): } 40 \mathrm{mg} \text { triamcinolone, } 3 \text { intra-articular injections, interval } 1 \text { week } \\
\text { Intervention (B): } 50 \mathrm{mg} \text { hydrocortisone, } 3 \text { intra-articular injections, interval } 1 \text { week } \\
\text { Control intervention } \\
\text { Saline solution (no dosage stated), } 2 \text { intra-articular injections, interval } 1 \text { week }\end{array}$} \\
\hline Outcomes & \multicolumn{2}{|c|}{$\begin{array}{l}\text { Extracted pain outcome: (A)-(B): other algofunctional } \\
\text { Extracted function outcome: (A)-(B): other algofunctional } \\
\text { Maximum follow-up: } 0.7 \text { weeks }\end{array}$} \\
\hline \multicolumn{3}{|l|}{ Notes } \\
\hline \multicolumn{3}{|l|}{ Risk of bias } \\
\hline Bias & Authors' judgement & Support for judgement \\
\hline $\begin{array}{l}\text { Random sequence generation (selection } \\
\text { bias) }\end{array}$ & Unclear risk & $\begin{array}{l}\text { Method used to generate random sequence } \\
\text { of allocation was not reported, so the risk } \\
\text { of selection bias was unclear }\end{array}$ \\
\hline Allocation concealment (selection bias) & Unclear risk & $\begin{array}{l}\text { Method used to conceal the random se- } \\
\text { quence of allocation was not reported, so } \\
\text { the risk of selection bias was unclear }\end{array}$ \\
\hline Blinding of participants? & Unclear risk & $\begin{array}{l}\text { It was unclear if method used to blind par- } \\
\text { ticipants was appropriate }\end{array}$ \\
\hline
\end{tabular}


Popov 1989 (Continued)

\begin{tabular}{l|l|l}
\hline Blinding of health care provider(s) & Unclear risk & $\begin{array}{l}\text { It was unclear if method used to blind } \\
\text { healthcare providers was appropriate }\end{array}$ \\
\hline $\begin{array}{l}\text { Intention-to-treat analysis performed? Pain } \\
\text { Intention-to-treat } \begin{array}{l}\text { Enalysis } \quad \text { performed? } \\
\text { Function }\end{array}\end{array}$ & Unclear risk & $\begin{array}{l}\text { It was unclear whether all participants ran- } \\
\text { domised were also analysed }\end{array}$ \\
\hline
\end{tabular}

\section{Ravaud 1999}

\begin{tabular}{|c|c|c|}
\hline Methods & \multicolumn{2}{|c|}{$\begin{array}{l}\text { Randomised controlled trial } \\
2 \times 2 \text { factorial design } \\
\text { Trial duration: } 24 \text { weeks }\end{array}$} \\
\hline Participants & \multicolumn{2}{|c|}{$\begin{array}{l}98 \text { participants with knee osteoarthritis were randomised } \\
98 \text { participants were reported at baseline } \\
\text { Number of females: } 66 \text { out of } 98(67 \%) \\
\text { Mean age: } 65.4\end{array}$} \\
\hline Interventions & \multicolumn{2}{|c|}{$\begin{array}{l}\text { Experimental interventions } \\
\text { Intervention (A): } 3.75 \mathrm{mg} \text { cortivazol }(1.5 \mathrm{ml}) \text {, single intra-articular injection } \\
\text { Intervention (B): Lavage, single intra-articular application }+3.75 \mathrm{mg} \text { cortivazol }(1.5 \mathrm{ml}) \\
\text {, single intra-articular injection } \\
\text { Control intervention } \\
\text { Intervention (A): } 1.5 \mathrm{ml} 0.9 \% \text { normal saline, single intra-articular injection } \\
\text { Intervention (B): Lavage, single intra-articular application }\end{array}$} \\
\hline Outcomes & \multicolumn{2}{|c|}{$\begin{array}{l}\text { Extracted pain outcome: Pain overall } \\
\text { Extracted function outcome: Lequesne index } \\
\text { Maximum follow-up: } 24 \text { weeks }\end{array}$} \\
\hline Notes & \multicolumn{2}{|c|}{$\begin{array}{l}\text { Funding: Société Française de Rhumatologie and the Direction de la Recherche Clinique } \\
\text { (Assistance Publique - Hôpitaux de Paris) }\end{array}$} \\
\hline \multicolumn{3}{|l|}{ Risk of bias } \\
\hline Bias & Authors' judgement & Support for judgement \\
\hline $\begin{array}{l}\text { Random sequence generation (selection } \\
\text { bias) }\end{array}$ & Unclear risk & $\begin{array}{l}\text { Method used to generate random sequence } \\
\text { of allocation was not reported, so the risk } \\
\text { of selection bias was unclear }\end{array}$ \\
\hline Allocation concealment (selection bias) & Unclear risk & $\begin{array}{l}\text { Method used to conceal the random se- } \\
\text { quence of allocation was not reported, so } \\
\text { the risk of selection bias was unclear }\end{array}$ \\
\hline
\end{tabular}


Ravaud 1999 (Continued)

\begin{tabular}{|c|c|c|}
\hline Blinding of participants? & Unclear risk & $\begin{array}{l}\text { Quote: "The study was double-blind in re- } \\
\text { lation to the IA corticosteroid and open } \\
\text { with regard to joint lavage." }\end{array}$ \\
\hline Blinding of health care provider(s) & Unclear risk & $\begin{array}{l}\text { Quote: "The study was double-blind in re- } \\
\text { lation to the IA corticosteroid and open } \\
\text { with regard to joint lavage. However, the } \\
\text { procedure (joint lavage and/or IA injection) } \\
\text { was performed by a physician other than } \\
\text { the blinded evaluator." }\end{array}$ \\
\hline Intention-to-treat analysis performed? Pain & Low risk & $\begin{array}{l}\text { All randomised participants included in the } \\
\text { analysis. Quote: "The last observation-car- } \\
\text { ried-forward procedure was used to adjust } \\
\text { for missing values." }\end{array}$ \\
\hline $\begin{array}{l}\text { Intention-to-treat analysis performed? } \\
\text { Function }\end{array}$ & Low risk & $\begin{array}{l}\text { All randomised participants included in the } \\
\text { analysis. Quote: "The last observation-car- } \\
\text { ried-forward procedure was used to adjust } \\
\text { for missing values." }\end{array}$ \\
\hline
\end{tabular}

\section{Raynauld 2003}

\begin{tabular}{l|l}
\hline Methods & $\begin{array}{l}\text { Randomised controlled trial } \\
\text { 2-arm parallel-group design } \\
\text { Trial duration: } 54 \text { weeks }\end{array}$ \\
\hline Participants & $\begin{array}{l}68 \text { participants with knee osteoarthritis were randomised } \\
68 \text { participants were reported at baseline } \\
\text { Number of females: } 42 \text { out of } 68 \text { (68\%) } \\
\text { Mean age: } 63.2 \text { years }\end{array}$ \\
\hline Interventions & $\begin{array}{l}\text { Experimental intervention } \\
40 \text { mg triamcinolone acetonide (1 ml), } 8 \text { intra-articular injections, interval } 3 \text { months, } \\
\text { over 21 months } \\
\text { Control intervention } \\
1 \text { ml saline intra-articularly, } 8 \text { intra-articular injections, interval } 3 \text { months, over } 21 \\
\text { months }\end{array}$ \\
\hline Eutcomes & $\begin{array}{l}\text { Extracted pain outcome: WOMAC Pain. After end of treatment (during follow-up) } \\
\text { Extracted function outcome: WOMAC Function. After end of treatment (during follow- } \\
\text { up) } \\
\text { Maximum follow-up: } 12.9 \text { weeks }\end{array}$ \\
\hline Notes & Funding: Fonds de la recherche en santé du Québec \\
\hline
\end{tabular}

Risk of bias

Intra-articular corticosteroid for knee osteoarthritis (Review) 
Raynauld 2003 (Continued)

\begin{tabular}{|c|c|c|}
\hline Bias & Authors' judgement & Support for judgement \\
\hline $\begin{array}{l}\text { Random sequence generation (selection } \\
\text { bias) }\end{array}$ & Low risk & $\begin{array}{l}\text { Quote: "Patients were randomly assigned } \\
\text { to the IA steroid or IA saline group based } \\
\text { on a table of randomly assorted digits." }\end{array}$ \\
\hline Allocation concealment (selection bias) & Unclear risk & $\begin{array}{l}\text { Method used to conceal the random se- } \\
\text { quence of allocation was not reported, so } \\
\text { the risk of selection bias was unclear }\end{array}$ \\
\hline Blinding of participants? & Unclear risk & $\begin{array}{l}\text { Study described as double-blind but no de- } \\
\text { scription of method of blinding provided }\end{array}$ \\
\hline Blinding of health care provider(s) & High risk & $\begin{array}{l}\text { Study described as double-blind. The fol- } \\
\text { lowing statements indicate that "double- } \\
\text { blind" in this trial means that only patients } \\
\text { and outcome assessors were blinded: "In } \\
\text { order to preserve the blind, the injections } \\
\text { were given by a rheumatologist (DC or BH) } \\
\text { other than the evaluators." "Investigators } \\
\text { performed these evaluations in a blinded } \\
\text { manner using validated measures." }\end{array}$ \\
\hline Intention-to-treat analysis performed? Pain & High risk & $\begin{array}{l}1 \text { of } 34 \text { participants excluded in experimen- } \\
\text { tal group, } 1 \text { of } 34 \text { participants excluded in } \\
\text { control group }\end{array}$ \\
\hline $\begin{array}{l}\text { Intention-to-treat analysis performed? } \\
\text { Function }\end{array}$ & High risk & $\begin{array}{l}1 \text { of } 34 \text { participants excluded in experimen- } \\
\text { tal group, } 1 \text { of } 34 \text { participants excluded in } \\
\text { control group }\end{array}$ \\
\hline
\end{tabular}

Schue 2011

\begin{tabular}{ll}
\hline Methods & $\begin{array}{l}\text { Randomised controlled trial } \\
\text { 3-arm parallel-group design } \\
\text { Trial duration: } 8 \text { weeks }\end{array}$ \\
\hline Participants & $\begin{array}{l}16 \text { participants with knee osteoarthritis were randomised } \\
\text { Unclear number of participants with knee osteoarthritis reported at baseline } \\
\text { Number of females: not reported } \\
\text { Mean age: not reported }\end{array}$ \\
\hline Interventions & $\begin{array}{l}\text { Experimental intervention } \\
80 \text { mg methylprednisolone, single intra-articular injection } \\
\text { Control intervention } \\
\text { Saline (no dosage specified), single intra-articular injection }\end{array}$ \\
\hline
\end{tabular}


Schue 2011 (Continued)

\begin{tabular}{|c|c|c|}
\hline Outcomes & \multicolumn{2}{|c|}{$\begin{array}{l}\text { Extracted pain outcome: WOMAC Global } \\
\text { Maximum follow-up: } 8 \text { weeks }\end{array}$} \\
\hline \multicolumn{3}{|l|}{ Notes } \\
\hline \multicolumn{3}{|l|}{ Risk of bias } \\
\hline Bias & Authors' judgement & Support for judgement \\
\hline $\begin{array}{l}\text { Random sequence generation (selection } \\
\text { bias) }\end{array}$ & Unclear risk & $\begin{array}{l}\text { Method used to generate random sequence } \\
\text { of allocation was not reported, so the risk } \\
\text { of selection bias was unclear }\end{array}$ \\
\hline Allocation concealment (selection bias) & Unclear risk & $\begin{array}{l}\text { Method used to conceal the random se- } \\
\text { quence of allocation was not reported, so } \\
\text { the risk of selection bias was unclear }\end{array}$ \\
\hline Blinding of participants? & Unclear risk & $\begin{array}{l}\text { It was unclear if method used to blind par- } \\
\text { ticipants was appropriate }\end{array}$ \\
\hline Blinding of health care provider(s) & Unclear risk & $\begin{array}{l}\text { Physicians were not explicitly described as } \\
\text { blinded, so the risk of performance bias was } \\
\text { unclear }\end{array}$ \\
\hline Intention-to-treat analysis performed? Pain & Unclear risk & $\begin{array}{l}\text { It was unclear whether all participants ran- } \\
\text { domised were also analysed }\end{array}$ \\
\hline $\begin{array}{l}\text { Intention-to-treat analysis performed? } \\
\text { Function }\end{array}$ & Unclear risk & $\begin{array}{l}\text { Not applicable, no function outcome re- } \\
\text { ported }\end{array}$ \\
\hline
\end{tabular}

Smith 2003

Methods

Randomised controlled trial

2-arm parallel-group design

Trial duration: 24 weeks

\begin{tabular}{l|l} 
Participants & 77 participants with knee osteoarthritis were randomised \\
& 71 participants were reported at baseline \\
& Number of females: 27 out of $77(35 \%)$ \\
& Mean age: 66.8 years \\
\hline Interventions & Experimental intervention \\
& 120 mg methylprednisolone acetate following joint lavage, single intra-articular injection \\
& Control intervention \\
Treatment duration: 1 day & Normal saline (no dosage) following joint lavage, single intra-articular injection
\end{tabular}

Intra-articular corticosteroid for knee osteoarthritis (Review) 
Smith 2003 (Continued)

\begin{tabular}{|c|c|c|}
\hline Outcomes & \multicolumn{2}{|c|}{$\begin{array}{l}\text { Extracted pain outcome: WOMAC Pain } \\
\text { Extracted function outcome: WOMAC Function } \\
\text { Maximum follow-up: } 24 \text { weeks }\end{array}$} \\
\hline Notes & \multicolumn{2}{|c|}{$\begin{array}{l}\text { Funding: National Health and Medical Research Council (Australia) Arthritis Founda- } \\
\text { tion of Australia }\end{array}$} \\
\hline \multicolumn{3}{|l|}{ Risk of bias } \\
\hline Bias & Authors' judgement & Support for judgement \\
\hline $\begin{array}{l}\text { Random sequence generation (selection } \\
\text { bias) }\end{array}$ & Low risk & $\begin{array}{l}\text { Quote: "Randomization was computer- } \\
\text { generated by a member of the hospital } \\
\text { pharmacy department, who also prepared } \\
\text { a blinded intra-articular injection" }\end{array}$ \\
\hline Allocation concealment (selection bias) & Low risk & $\begin{array}{l}\text { Quote: "Randomization was computer- } \\
\text { generated by a member of the hospital } \\
\text { pharmacy department, who also prepared } \\
\text { a blinded intra-articular injection" }\end{array}$ \\
\hline Blinding of participants? & Unclear risk & $\begin{array}{l}\text { It was unclear if method used to blind par- } \\
\text { ticipants was appropriate }\end{array}$ \\
\hline Blinding of health care provider(s) & Unclear risk & $\begin{array}{l}\text { It was unclear if method used to blind } \\
\text { healthcare providers was appropriate }\end{array}$ \\
\hline Intention-to-treat analysis performed? Pain & High risk & $\begin{array}{l}\text { Quote: "In the event of relapse as defined } \\
\text { above, the last documented outcome vari- } \\
\text { ables were carried forward". Still, } 6 \text { partic- } \\
\text { ipants were excluded (those needing surgi- } \\
\text { cal intervention because of the arthroscopic } \\
\text { findings at baseline) }\end{array}$ \\
\hline $\begin{array}{l}\text { Intention-to-treat analysis performed? } \\
\text { Function }\end{array}$ & High risk & $\begin{array}{l}\text { Quote: "In the event of relapse as defined } \\
\text { above, the last documented outcome vari- } \\
\text { ables were carried forward". Still, } 6 \text { partic- } \\
\text { ipants were excluded (those needing surgi- } \\
\text { cal intervention because of the arthroscopic } \\
\text { findings at baseline) }\end{array}$ \\
\hline
\end{tabular}


Wright 1960

\begin{tabular}{|c|c|c|}
\hline Methods & \multicolumn{2}{|c|}{$\begin{array}{l}\text { Randomised controlled trial } \\
\text { 3-arm parallel-group design } \\
\text { Trial duration: } 20 \text { weeks }\end{array}$} \\
\hline Participants & \multicolumn{2}{|c|}{$\begin{array}{l}38 \text { knees belonging to } 25 \text { participants with knee osteoarthritis were randomised } \\
\text { Unclear number of participants with knee osteoarthritis reported at baseline } \\
\text { Number of females: not stated } \\
\text { Mean age: not stated }\end{array}$} \\
\hline Interventions & \multicolumn{2}{|c|}{$\begin{array}{l}\text { Experimental intervention } \\
\text { Intervention (A): } 25 \mathrm{mg} \text { hydrocortisone acetate }(1 \mathrm{ml}), 4 \text { intra-articular injections, in- } \\
\text { terval } 2 \text { weeks over } 6 \text { weeks } \\
\text { Intervention (B): } 25 \mathrm{mg} \text { hydrocortisone tertiary-butylacetate }(1 \mathrm{ml}), 4 \text { intra-articular } \\
\text { injections, interval } 2 \text { weeks over } 6 \text { weeks } \\
\text { Control intervention } \\
1 \mathrm{ml} \text { of placebo, } 4 \text { intra-articular injections, interval } 2 \text { weeks over } 6 \text { weeks } \\
\text { Cross-over design, every participant received } 3 \times 4 \text { injections }\end{array}$} \\
\hline Outcomes & \multicolumn{2}{|c|}{ Only information on adverse events was extracted } \\
\hline Notes & \multicolumn{2}{|c|}{ There was no extractable data on pain or function } \\
\hline \multicolumn{3}{|l|}{ Risk of bias } \\
\hline Bias & Authors' judgement & Support for judgement \\
\hline $\begin{array}{l}\text { Random sequence generation (selection } \\
\text { bias) }\end{array}$ & Unclear risk & $\begin{array}{l}\text { Quote: "The order of courses in each pa- } \\
\text { tient was randomized from a master sheet } \\
\text { in which names were entered consecutively. } \\
\text { " }\end{array}$ \\
\hline Allocation concealment (selection bias) & Unclear risk & $\begin{array}{l}\text { Method used to conceal the random se- } \\
\text { quence of allocation was not reported, so } \\
\text { the risk of selection bias was unclear }\end{array}$ \\
\hline Blinding of participants? & Unclear risk & $\begin{array}{l}\text { It was unclear if method used to blind par- } \\
\text { ticipants was appropriate }\end{array}$ \\
\hline Blinding of health care provider(s) & Unclear risk & $\begin{array}{l}\text { Physicians were not explicitly described as } \\
\text { blinded, so the risk of performance bias was } \\
\text { unclear }\end{array}$ \\
\hline Intention-to-treat analysis performed? Pain & Unclear risk & $\begin{array}{l}\text { Did not report extractable pain outcome } \\
\text { data }\end{array}$ \\
\hline $\begin{array}{l}\text { Intention-to-treat analysis performed? } \\
\text { Function }\end{array}$ & Unclear risk & $\begin{array}{l}\text { Did not report extractable function out- } \\
\text { come data excluded in control group }\end{array}$ \\
\hline
\end{tabular}

Intra-articular corticosteroid for knee osteoarthritis (Review) 
Yavuz 2012

\begin{tabular}{|c|c|}
\hline Methods & $\begin{array}{l}\text { Randomised controlled trial } \\
\text { 4-arm parallel-group design } \\
\text { Trial duration: } 12 \text { weeks }\end{array}$ \\
\hline Participants & $\begin{array}{l}120 \text { participants with knee osteoarthritis were randomised } \\
120 \text { participants were reported at baseline } \\
\text { Number of females: } 76 \text { out of } 120(63 \%) \\
\text { Mean age: } 60.0 \text { years }\end{array}$ \\
\hline Interventions & $\begin{array}{l}\text { Experimental intervention } \\
\text { Intervention (A): } 40 \mathrm{mg} \text { triamsinolon acetonate }(1 \mathrm{ml}) \text {, single intra-articular injection } \\
\text { Intervention (B): } 3 \mathrm{mg} \text { betametazone disodium phosphate }(1 \mathrm{ml}) \text {, single intra-articular } \\
\text { injection } \\
\text { Intervention }(\mathrm{C}): 40 \mathrm{mg} \text { methylprednisolone acetate }(1 \mathrm{ml}) \text {, single intra-articular injec- } \\
\text { tion } \\
\text { Control intervention } \\
1 \mathrm{ml} 0.9 \% \text { sodium chloride, single intra-articular injection }\end{array}$ \\
\hline Outcomes & $\begin{array}{l}\text { Extracted pain outcome (A)-(C): Pain overall } \\
\text { Extracted function outcome (A)-(C): Lequesne index } \\
\text { Maximum follow-up: } 12 \text { weeks }\end{array}$ \\
\hline Notes & \\
\hline
\end{tabular}

Risk of bias

\begin{tabular}{|c|c|c|}
\hline Bias & Authors' judgement & Support for judgement \\
\hline $\begin{array}{l}\text { Random sequence generation (selection } \\
\text { bias) }\end{array}$ & High risk & $\begin{array}{l}\text { Quote: "A total of } 120 \text { eligible patients with } \\
\text { knee osteoarthritis were included (accord- } \\
\text { ing to their admission date) and random- } \\
\text { ized into four groups." }\end{array}$ \\
\hline Allocation concealment (selection bias) & Unclear risk & $\begin{array}{l}\text { Method used to conceal the random se- } \\
\text { quence of allocation was not reported, so } \\
\text { the risk of selection bias was unclear }\end{array}$ \\
\hline Blinding of participants? & Unclear risk & It was unclear if participants were blinded \\
\hline Blinding of health care provider(s) & Unclear risk & $\begin{array}{l}\text { Physicians were not explicitly described as } \\
\text { blinded, so the risk of performance bias was } \\
\text { unclear }\end{array}$ \\
\hline Intention-to-treat analysis performed? Pain & Unclear risk & $\begin{array}{l}\text { It was unclear whether all participants ran- } \\
\text { domised were also analysed }\end{array}$ \\
\hline $\begin{array}{l}\text { Intention-to-treat analysis performed? } \\
\text { Function }\end{array}$ & Unclear risk & $\begin{array}{l}\text { It was unclear whether all participants ran- } \\
\text { domised were also analysed }\end{array}$ \\
\hline
\end{tabular}

Intra-articular corticosteroid for knee osteoarthritis (Review) 
Young 2001

\begin{tabular}{ll}
\hline Methods & $\begin{array}{l}\text { Randomised controlled trial } \\
\text { 2-arm parallel-group design } \\
\text { Trial duration: } 4.3 \text { weeks }\end{array}$ \\
\hline Participants & $\begin{array}{l}41 \text { knees belonging to } 40 \text { participants with knee osteoarthritis were randomised } \\
\text { Unclear number of participants with knee osteoarthritis reported at baseline } \\
\text { Number of females: } 16\end{array}$ \\
\hline Mean age: 66.5 years
\end{tabular}

\section{Risk of bias}

\begin{tabular}{l|l|l}
\hline Bias & Authors' judgement & Support for judgement \\
\hline $\begin{array}{l}\text { Random sequence generation (selection } \\
\text { bias) }\end{array}$ & Unclear risk & $\begin{array}{l}\text { Method used to generate random sequence } \\
\text { of allocation was not reported, so the risk } \\
\text { of selection bias was unclear }\end{array}$ \\
\hline Allocation concealment (selection bias) & Unclear risk & $\begin{array}{l}\text { Method used to conceal the random se- } \\
\text { quence of allocation was not reported, so } \\
\text { the risk of selection bias was unclear }\end{array}$ \\
\hline Blinding of participants? & Unclear risk & It was unclear if method used to blind par- \\
\hline ticipants was appropriate
\end{tabular}

Intra-articular corticosteroid for knee osteoarthritis (Review) 
Zhilyayev 2012

\begin{tabular}{|c|c|c|}
\hline Methods & \multicolumn{2}{|c|}{$\begin{array}{l}\text { Randomised controlled trial } \\
\text { 4-arm parallel-group design } \\
\text { Trial duration: } 12 \text { weeks }\end{array}$} \\
\hline Participants & \multicolumn{2}{|c|}{$\begin{array}{l}209 \text { knees belonging to } 112 \text { participants were randomised } \\
\text { Unclear number of participants with knee osteoarthritis reported at baseline } \\
\text { Number of females: not stated } \\
\text { Mean age: not stated }\end{array}$} \\
\hline Interventions & \multicolumn{2}{|c|}{$\begin{array}{l}\text { Experimental intervention } \\
20 \mathrm{mg} \text { triamcinolone acetonid plus } 10 \mathrm{ml} 0.5 \% \text { procaine, single intra-articular injection } \\
\text { Control intervention } \\
10 \mathrm{ml} 0.5 \% \text { procaine, single intra-articular injection }\end{array}$} \\
\hline Outcomes & \multicolumn{2}{|c|}{$\begin{array}{l}\text { Extracted pain outcome: WOMAC Pain } \\
\text { Maximum follow-up: } 12 \text { weeks }\end{array}$} \\
\hline \multicolumn{3}{|l|}{ Notes } \\
\hline \multicolumn{3}{|l|}{ Risk of bias } \\
\hline Bias & Authors' judgement & Support for judgement \\
\hline $\begin{array}{l}\text { Random sequence generation (selection } \\
\text { bias) }\end{array}$ & Unclear risk & $\begin{array}{l}\text { Quote: "joints were randomized by en- } \\
\text { velopes to one of } 4 \text { treatments" }\end{array}$ \\
\hline Allocation concealment (selection bias) & Unclear risk & $\begin{array}{l}\text { Quote: "joints were randomized by en- } \\
\text { velopes to one of } 4 \text { treatments" }\end{array}$ \\
\hline Blinding of participants? & Unclear risk & $\begin{array}{l}\text { It was unclear if method used to blind par- } \\
\text { ticipants was appropriate }\end{array}$ \\
\hline Blinding of health care provider(s) & Unclear risk & $\begin{array}{l}\text { Physicians were not explicitly described as } \\
\text { blinded, so the risk of performance bias was } \\
\text { unclear }\end{array}$ \\
\hline Intention-to-treat analysis performed? Pain & Unclear risk & $\begin{array}{l}\text { It was unclear whether all participants ran- } \\
\text { domised were also analysed }\end{array}$ \\
\hline $\begin{array}{l}\text { Intention-to-treat analysis performed? } \\
\text { Function }\end{array}$ & Unclear risk & $\begin{array}{l}\text { Not applicable, no function outcome re- } \\
\text { ported }\end{array}$ \\
\hline
\end{tabular}

IA: intra-articular

WOMAC: Western Ontario and McMaster Universities Arthritis Index 
Characteristics of excluded studies [ordered by study ID]

\begin{tabular}{|c|c|}
\hline Study & Reason for exclusion \\
\hline Abdulla 2013 & Recent systematic review \\
\hline Anonymous 1978 & Wrong study design \\
\hline Anonymous 2011 & Wrong study design \\
\hline Arroll 2004 & Recent systematic review \\
\hline Arroll 2005 & Wrong study design \\
\hline Avouac 2010 & Recent systematic review \\
\hline Baker 1969 & Active comparator \\
\hline Bannuru 2013 & Wrong study design: Abstract to relevant systematic review, no references listed \\
\hline Bannuru 2014 & Wrong study design: Abstract to relevant systematic review, no references listed \\
\hline Bannuru 2015 & Recent systematic review \\
\hline Baratham 2010 & Wrong outcomes \\
\hline Bellamy 2005 & Recent systematic review \\
\hline Bellamy 2006 & Recent systematic review \\
\hline Bennell 2012 & Wrong study design \\
\hline Bjordal 2007 & Recent systematic review \\
\hline Blanke 2008 & Wrong study design \\
\hline Bourne 1985 & Wrong study design \\
\hline Brys 2004 & Wrong study design \\
\hline Canillas 2011 & Wrong study design \\
\hline Cats $1979 b$ & Wrong study population \\
\hline Charalambous 2004 & Wrong study design \\
\hline Cheng 2012 & Recent systematic review \\
\hline
\end{tabular}


(Continued)

\begin{tabular}{|c|c|}
\hline Courtney 2009 & Wrong study design \\
\hline Douglas 2012 & Wrong study design \\
\hline Gait 2014 & Wrong study design \\
\hline Garg 2013 & $\begin{array}{l}\text { Wrong study design: Abstract to relevant systematic review } \\
\text {, no references listed }\end{array}$ \\
\hline Garg 2014 & Reason for exclusion \\
\hline Gerlag 2008a & Wrong study design \\
\hline Godwin 2004 & Recent systematic review \\
\hline Habib 2009 & Wrong study design \\
\hline Habib 2010 & Wrong study design \\
\hline Hepper 2009 & Reason for exclusion \\
\hline Hirsch 2013 & Reason for exclusion \\
\hline Ivanov 1981 & Wrong comparator \\
\hline Jarner 1992 & Active comparator \\
\hline Jones 1993 & Wrong study design \\
\hline Jones 2014 & Wrong study design \\
\hline Keagy 1967 & Wrong study design \\
\hline Khitrov 1997 & Active comparator \\
\hline Kizilkaya 2004 & Postsurgical setting \\
\hline Kizilkaya 2005 & Postsurgical setting \\
\hline Koyonos 2009 & Postsurgical setting \\
\hline Krause 1971 & Wrong study design \\
\hline Legre-Boyer 2015 & Wrong study design \\
\hline Lequesne 1970 & Wrong study design \\
\hline
\end{tabular}


(Continued)

\begin{tabular}{|c|c|}
\hline Maricar 2013 & $\begin{array}{l}\text { Wrong study design: Abstract to relevant systematic review } \\
\text {, no references listed }\end{array}$ \\
\hline Maricar 2013c & Recent systematic review \\
\hline Maricar 2014 & Wrong study design \\
\hline McAlindon 2014 & Wrong study design \\
\hline Murdoch 1959 & Wrong study design \\
\hline Murdoch 1959a & Wrong study design \\
\hline Neame 2003 & Wrong study design \\
\hline Nicol 1972 & Wrong study design \\
\hline No named author & Wrong study design \\
\hline No named author a & Wrong study design \\
\hline No named author $b$ & Wrong study design \\
\hline No named author c & Wrong study design \\
\hline Parmigiani 2010 & Duplicate reference \\
\hline Pendleton 2008 & Wrong study design \\
\hline Punzi 2001 & Wrong intervention \\
\hline Rasmussen 1998 & Postsurgical setting \\
\hline Rasmussen 1998a & Postsurgical setting \\
\hline Rasmussen 1998b & Postsurgical setting \\
\hline Reshetov 2000 & Wrong comparator \\
\hline Ronchetti 2001 & Active comparator \\
\hline Roskos 2005 & Wrong study design \\
\hline Saito 1971 & Wrong study design \\
\hline Shah 1967 & Wrong comparator \\
\hline
\end{tabular}


(Continued)

\begin{tabular}{|c|c|}
\hline Sheldon 1973 & Wrong study population \\
\hline Stein 1996 & Active comparator \\
\hline Stitik 2006 & Wrong study design \\
\hline Stojanovic 1969 & Wrong study design \\
\hline Talke 1986 & Wrong study design \\
\hline Van Middelkoop 2013 & $\begin{array}{l}\text { Wrong study design: Abstract to relevant systematic review } \\
\text {, no references listed }\end{array}$ \\
\hline Van Middelkoop 2013a & $\begin{array}{l}\text { Wrong study design: Abstract to relevant systematic review } \\
\text {, no references listed }\end{array}$ \\
\hline Van Middelkoop 2013b & Wrong study design \\
\hline Van Middelkoop 2014 & $\begin{array}{l}\text { Wrong study design: Abstract to relevant systematic review } \\
\text {, no references listed }\end{array}$ \\
\hline Van Middelkoop 2014a & $\begin{array}{l}\text { Wrong study design: Abstract to relevant systematic review } \\
\text {, no references listed }\end{array}$ \\
\hline Wang 1998 & Postsurgical setting \\
\hline Wang 2015 & Wrong study design \\
\hline Wramner 1959 & Wrong study design \\
\hline Yamamoto 1970 & Wrong study design \\
\hline Zhang 2008 & Wrong study design \\
\hline Zhang 2010 & Wrong study design \\
\hline Zuckner 1958 & Active comparator \\
\hline
\end{tabular}




\section{Characteristics of studies awaiting assessment [ordered by study ID]}

\section{Ellis 2011}

\begin{tabular}{l|l}
\hline Methods & $\begin{array}{l}\text { Randomised controlled trial } \\
\text { 2-arm parallel-group design } \\
\text { Trial duration: } 12 \text { weeks }\end{array}$ \\
\hline Participants & 16 participants with knee osteoarthritis were randomised \\
\hline Interventions & $\begin{array}{l}\text { Experimental intervention } \\
\text { 3-month exercise program plus } 40 \mathrm{mg} \text { triamcinolone mixed with } 4 \mathrm{ml} 1 \% \text { lidocaine, single intra-articular injection } \\
\text { Control intervention } \\
\text { 3-month exercise program plus } 1 \mathrm{ml} \text { normal saline mixed with } 4 \mathrm{ml} 1 \% \text { lidocaine, single intra-articular injection }\end{array}$ \\
\hline Outcomes & $\begin{array}{l}\text { Maximum follow-up: } 12 \mathrm{weeks} \\
\text { Outcome data (KOOS pain and function, WOMAC pain and function) not extractable }\end{array}$ \\
\hline Notes & \\
\hline
\end{tabular}

Friedman 1978

\begin{tabular}{ll}
\hline Methods & Unclear \\
\hline Participants & Unclear \\
\hline Interventions & Unclear \\
\hline Outcomes & Outcome data not extractable \\
\hline Notes & \\
\hline
\end{tabular}

Hall 2013

\begin{tabular}{ll}
\hline Methods & $\begin{array}{l}\text { Randomised controlled trial } \\
\text { 2-arm parallel-group design }\end{array}$ \\
\hline Participants & 25 participants with knee osteoarthritis were randomised \\
\hline Interventions & $\begin{array}{l}\text { Experimental intervention } \\
\text { 40 mg methylprednisolone acetate, single intra-articular injection } \\
\text { Control intervention } \\
\text { saline, single intra-articular injection } \\
\text { Cross-over design: Every participant received 1 injection each }\end{array}$ \\
\hline Outcomes & $\begin{array}{l}\text { Maximum follow-up: 1 week } \\
\text { Outcome data (WOMAC pain, pain overall, ICOAP questionnaire, ultrasound examination) not extractable }\end{array}$ \\
\hline Notes & \\
\hline
\end{tabular}


Hall 2014

\begin{tabular}{l|l}
\hline Methods & $\begin{array}{l}\text { Randomised controlled trial } \\
\text { 2-arm parallel-group design }\end{array}$ \\
\hline Participants & 25 participants with knee osteoarthritis were randomised \\
\hline Interventions & $\begin{array}{l}\text { Experimental intervention } \\
40 \text { mg methylprednisolone acetate, single intra-articular injection } \\
\text { Control intervention } \\
\text { saline, single intra-articular injection } \\
\text { Cross-over design: Every participant received 1 injection each }\end{array}$ \\
\hline Outcomes & $\begin{array}{l}\text { Maximum follow-up: 1 week } \\
\text { Outcome data (WOMAC pain, pain overall, ICOAP questionnaire, ultrasound examination) not extractable }\end{array}$ \\
\hline Notes & \\
\hline
\end{tabular}

\section{Motyl 2013}

\begin{tabular}{l|l}
\hline Methods & $\begin{array}{l}\text { Measurement reliability study on participants later taking part in a randomised controlled trial for intra-articular } \\
\text { corticosteroid injection in knee osteoarthritis }\end{array}$ \\
\hline Participants & 15 participants with knee osteoarthritis \\
\hline Interventions & $\begin{array}{l}\text { Unclear } \\
\text { Data for the study was collected before the intra-articular injection }\end{array}$ \\
\hline Outcomes & Outcome data not extractable \\
\hline Notes &
\end{tabular}

Motyl 2013a

\begin{tabular}{l|l} 
Methods & $\begin{array}{l}\text { Measurement reliability study on participants later taking part in a randomised controlled trial for intra-articular } \\
\text { corticosteroid injection in knee osteoarthritis }\end{array}$ \\
\hline Participants & 15 participants with knee osteoarthritis \\
\hline Interventions & $\begin{array}{l}\text { Unclear } \\
\text { Data for the study was collected before the intra-articular injection }\end{array}$ \\
\hline Outcomes & Outcome data not extractable \\
\hline Notes &
\end{tabular}


O’Neill 2014

\begin{tabular}{ll} 
Methods & Open-label clinical trial \\
\hline Participants & 100 participants with knee osteoarthritis \\
\hline Interventions & $\begin{array}{l}\text { Experimental intervention } \\
\text { Corticosteroid, single intra-articular injection, type and dosage of corticosteroid unclear } \\
\text { The study analysed the changes in MRI scans before and after the intra-articular corticosteroid injection. All partic- } \\
\text { ipants received the experimental intervention, there was no control group }\end{array}$ \\
\hline Outcomes & Outcome data not extractable \\
\hline Notes & \\
\hline
\end{tabular}

\section{Raynauld 1999}

\begin{tabular}{l|l}
\hline Methods & $\begin{array}{l}\text { Randomised controlled trial } \\
\text { 2-arm parallel-group design }\end{array}$ \\
\hline Participants & 80 participants with knee osteoarthritis were randomised \\
\hline Interventions & $\begin{array}{l}\text { Experimental intervention } \\
40 \text { mg triamcinolone hexacetonide, } 8 \text { intra-articular injections, } 3 \text { months interval } \\
\text { Control intervention } \\
\text { Placebo, } 8 \text { intra-articular injections, } 3 \text { months interval }\end{array}$ \\
\hline Outcomes & Outcome data (pain overall, WOMAC) not extractable \\
\hline Notes & \\
\hline
\end{tabular}

Rezende 2012

\begin{tabular}{ll} 
Methods & $\begin{array}{l}\text { Randomised controlled trial } \\
\text { 2-arm parallel-group design }\end{array}$ \\
\hline Participants & 104 participants with knee osteoarthritis were randomised \\
\hline Interventions & $\begin{array}{l}\text { Experimental intervention } \\
\text { 20 mg of hexacetonide triamcinolone plus } 6 \mathrm{ml} \text { of hylan GF-20, single intra-articular injection } \\
\text { Control intervention } \\
6 \text { ml of hylan GF-20, single intra-articular injection }\end{array}$ \\
\hline Outcomes & $\begin{array}{l}\text { Maximum follow-up: 24 weeks } \\
\text { Outcome data (VAS, WOMAC, and Lequesne) not extractable }\end{array}$ \\
\hline Notes &
\end{tabular}


Singh 1996

\begin{tabular}{ll}
\hline Methods & Unclear \\
\hline Participants & Unclear \\
\hline Interventions & Unclear \\
\hline Outcomes & Outcome data not extractable \\
\hline Notes & \\
\hline
\end{tabular}

ICOAP: Intermittent and Constant Osteoarthritis Pain

KOOS: Knee Injury and Osteoarthritis Outcome Score

MRI: magnetic resonance imaging

VAS: visual analogue scale

WOMAC: Western Ontario and McMaster Universities Arthritis Index 
DATA AND ANALYSES

\section{Comparison 1. Pain}

\begin{tabular}{lcclll} 
Outcome or subgroup title & $\begin{array}{c}\text { No. of } \\
\text { studies }\end{array}$ & $\begin{array}{c}\text { No. of } \\
\text { participants }\end{array}$ & \multicolumn{1}{c}{ Statistical method } & Effect size \\
\hline 1 Pain - Main & 26 & 1749 & Std. Mean Difference (Random, 95\% CI) & $-0.40[-0.58,-0.22]$ \\
2 Pain - Timepoints & 26 & & Std. Mean Difference (Random, 95\% CI) & Subtotals only \\
2.1 Pain- 1-2 week & 16 & 1041 & Std. Mean Difference (Random, 95\% CI) & $-0.48[-0.70,-0.27]$ \\
2.2 Pain- 4-6 week & 22 & 1529 & Std. Mean Difference (Random, 95\% CI) & $-0.41[-0.61,-0.21]$ \\
2.3 Pain- 3 months & 18 & 1233 & Std. Mean Difference (Random, 95\% CI) & $-0.22[-0.44,4.12]$ \\
2.4 Pain- 6 months & 7 & 526 & Std. Mean Difference (Random, 95\% CI) & $-0.07[-0.25,0.11]$ \\
\hline
\end{tabular}

Comparison 2. Function

\begin{tabular}{lcclll} 
Outcome or subgroup title & $\begin{array}{c}\text { No. of } \\
\text { studies }\end{array}$ & $\begin{array}{c}\text { No. of } \\
\text { participants }\end{array}$ & \multicolumn{1}{c}{ Statistical method } & Effect size \\
\hline 1 Function - Main & 15 & 1014 & Std. Mean Difference (Random, 95\% CI) & $-0.33[-0.56,-0.09]$ \\
2 Function - Timepoints & 15 & & Std. Mean Difference (Random, 95\% CI) & Subtotals only \\
2.1 Function - 1-2 weeks & 10 & 763 & Std. Mean Difference (Random, 95\% CI) & $-0.43[-0.72,-0.14]$ \\
2.2 Function - 4-6 weeks & 12 & 818 & Std. Mean Difference (Random, 95\% CI) & $-0.36[-0.63,-0.09]$ \\
2.3 Function - 3 months & 11 & 800 & Std. Mean Difference (Random, 95\% CI) & $-0.13[-0.37,0.10]$ \\
2.4 Function - 6 months & 4 & 328 & Std. Mean Difference (Random, 95\% CI) & $0.06[-0.16,0.28]$ \\
\hline
\end{tabular}

Comparison 3. Quality of life

\begin{tabular}{lccccc} 
Outcome or subgroup title & $\begin{array}{c}\text { No. of } \\
\text { studies }\end{array}$ & $\begin{array}{c}\text { No. of } \\
\text { participants }\end{array}$ & Statistical method & Effect size \\
\hline 1 Quality of life - Main & 2 & 184 & Std. Mean Difference (Random, 95\% CI) & $-0.01[-0.30,0.28]$ \\
\hline
\end{tabular}


Comparison 4. Number of participants experiencing any adverse event

\begin{tabular}{lcccc} 
Outcome or subgroup title & $\begin{array}{c}\text { No. of } \\
\text { studies }\end{array}$ & $\begin{array}{c}\text { No. of } \\
\text { participants }\end{array}$ & Statistical method & Effect size \\
\hline $\begin{array}{l}\text { 1 Number of participants } \\
\text { experiencing any adverse event } \\
\text { - Main }\end{array}$ & 2 & 84 & Risk Ratio (IV, Random, 95\% CI) & $0.89[0.64,1.23]$ \\
\hline
\end{tabular}

Comparison 5. Number of participants who withdraw because of adverse events

\begin{tabular}{lcccc} 
Outcome or subgroup title & $\begin{array}{c}\text { No. of } \\
\text { studies }\end{array}$ & $\begin{array}{c}\text { No. of } \\
\text { participants }\end{array}$ & Statistical method & Effect size \\
\hline $\begin{array}{l}1 \text { Number of participants who } \\
\text { with draw because of adverse } \\
\text { events -Main }\end{array}$ & 2 & 204 & Risk Ratio (IV, Random, 95\% CI) & 0.33 [0.05, 2.07] \\
\hline
\end{tabular}

Comparison 6. Number of participants experiencing any serious adverse event

\begin{tabular}{lcccc} 
Outcome or subgroup title & $\begin{array}{c}\text { No. of } \\
\text { studies }\end{array}$ & $\begin{array}{c}\text { No. of } \\
\text { participants }\end{array}$ & Statistical method & Effect size \\
\hline $\begin{array}{l}\text { 1 Number of participants } \\
\text { experiencing any serious } \\
\text { adverse event - Main }\end{array}$ & 5 & 331 & Risk Ratio (IV, Random, 95\% CI) & $0.63[0.15,2.67]$ \\
\hline
\end{tabular}

Comparison 7. Joint space narrowing

\begin{tabular}{lcccc} 
Outcome or subgroup title & $\begin{array}{c}\text { No. of } \\
\text { studies }\end{array}$ & $\begin{array}{c}\text { No. of } \\
\text { participants }\end{array}$ & Statistical method & Effect size \\
\hline 1 Joint space narrowing - Main & 1 & 68 & Std. Mean Difference (Random, 95\% CI) & $-0.02[-0.49,0.46]$ \\
\hline
\end{tabular}




\section{Analysis I.I. Comparison I Pain, Outcome I Pain - Main.}

Review: Intra-articular corticosteroid for knee osteoarthritis

Comparison: I Pain

Outcome: I Pain - Main

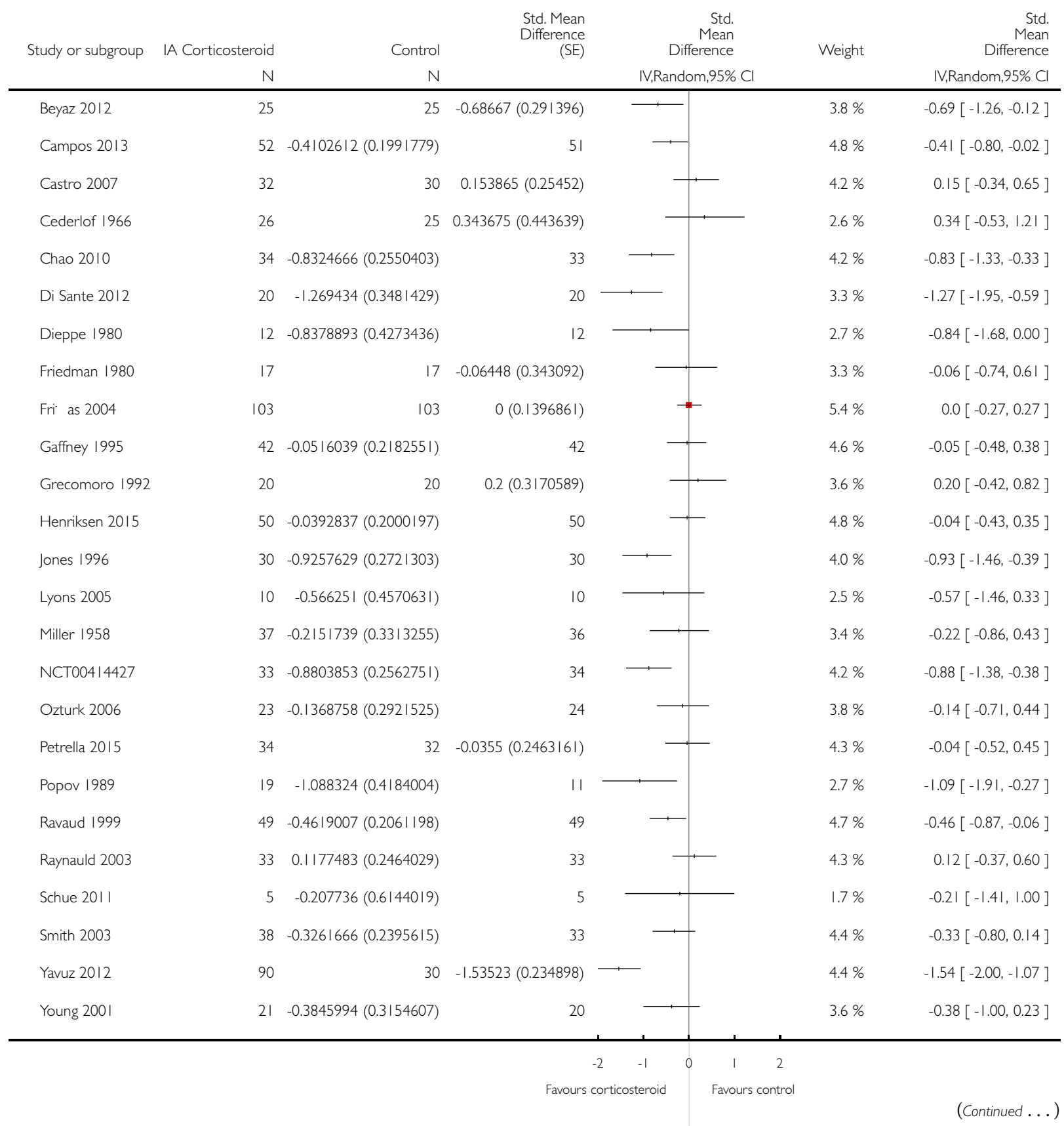

Intra-articular corticosteroid for knee osteoarthritis (Review) 


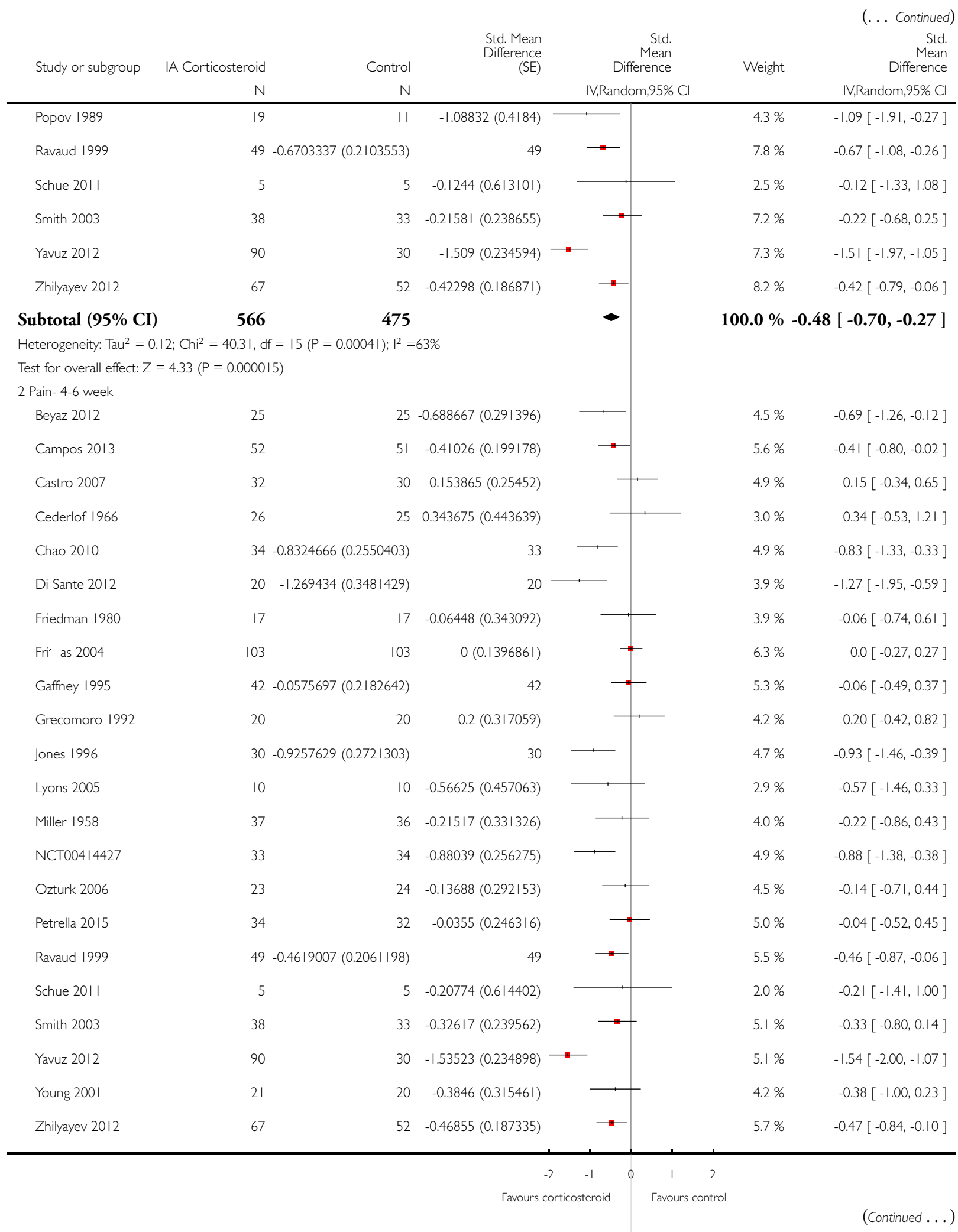

Intra-articular corticosteroid for knee osteoarthritis (Review) 


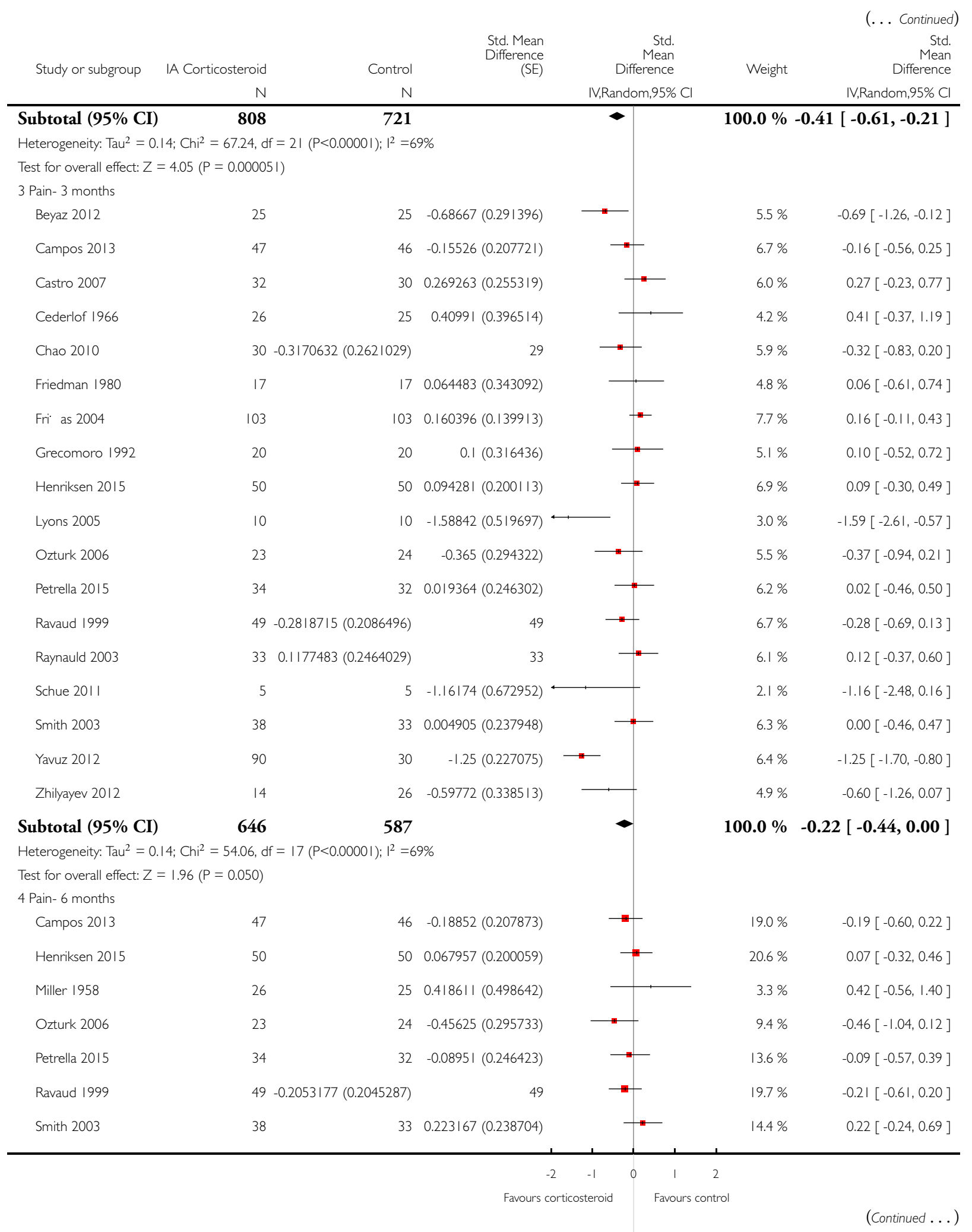

Intra-articular corticosteroid for knee osteoarthritis (Review) 


\begin{tabular}{|c|c|c|c|c|c|c|}
\hline \multirow[t]{2}{*}{ Study or subgroup } & IA Corticosteroid & Control & $\begin{array}{r}\text { Std. Mean } \\
\text { Difference } \\
\text { (SE) }\end{array}$ & $\begin{array}{r}\text { Std. } \\
\text { Mean } \\
\text { Difference }\end{array}$ & \multirow[t]{2}{*}{ Weight } & $\begin{array}{r}\text { (... Continued) } \\
\text { Std. } \\
\text { Mean } \\
\text { Difference }\end{array}$ \\
\hline & N & N & \multicolumn{2}{|r|}{ IV,Random,95\% Cl } & & IV,Random,95\% Cl \\
\hline Subtotal $(95 \% \mathrm{CI})$ & 267 & 259 & & 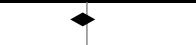 & $100.0 \%$ & $-0.07[-0.25,0.11]$ \\
\hline \multicolumn{7}{|c|}{ Heterogeneity: Tau $^{2}=0.0 ; \mathrm{Chi}^{2}=5.42, \mathrm{df}=6(P=0.49) ; \mathrm{I}^{2}=0.0 \%$} \\
\hline \multicolumn{7}{|c|}{ Test for overall effect: $Z=0.79(P=0.43)$} \\
\hline \multicolumn{7}{|c|}{ Test for subgroup differences: Chi $^{2}=10.59, \mathrm{df}=3(P=0.01), 1^{2}=72 \%$} \\
\hline
\end{tabular}

\section{Analysis 2.I. Comparison 2 Function, Outcome I Function - Main.}

Review: Intra-articular corticosteroid for knee osteoarthritis

Comparison: 2 Function

Outcome: I Function - Main

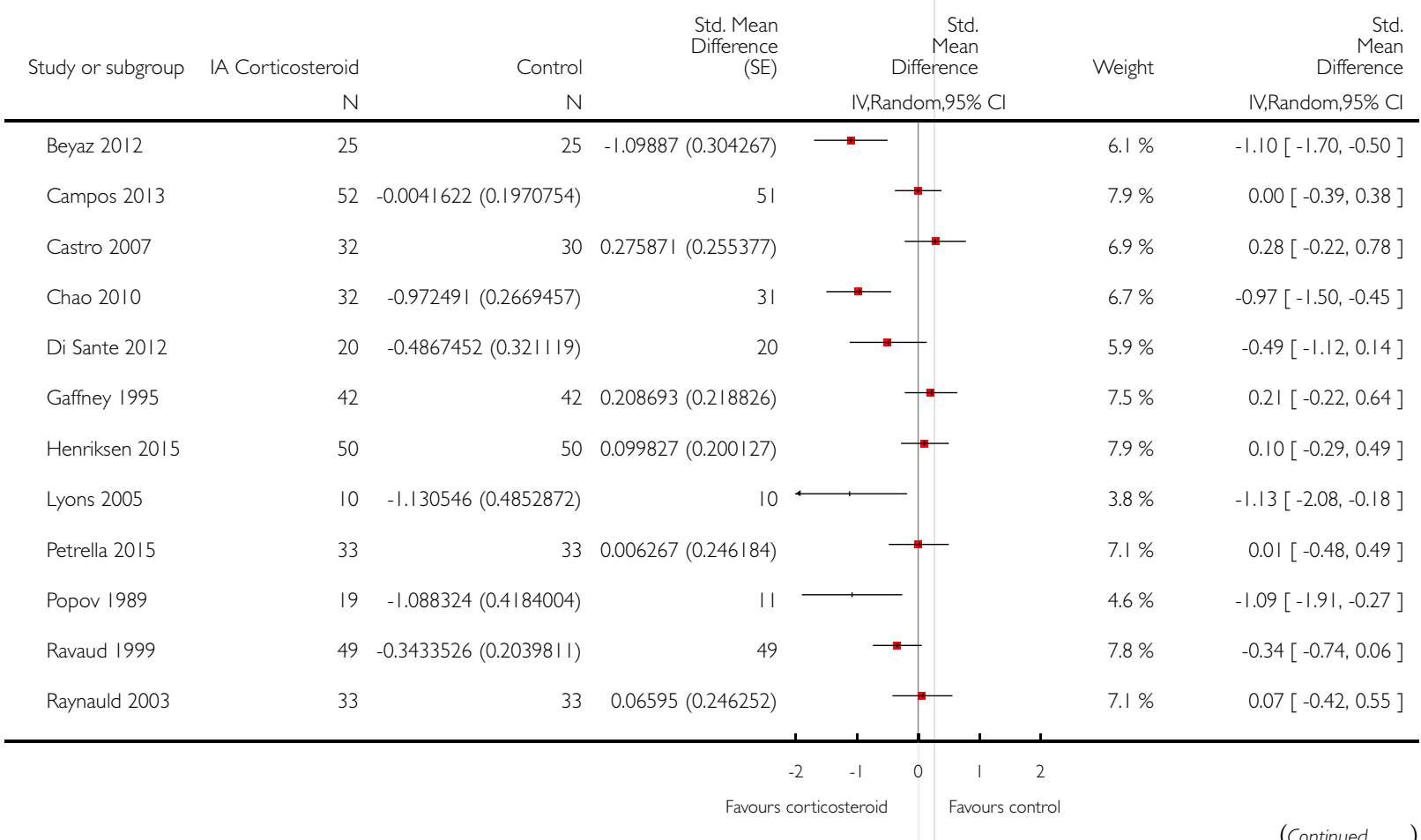

Intra-articular corticosteroid for knee osteoarthritis (Review) 


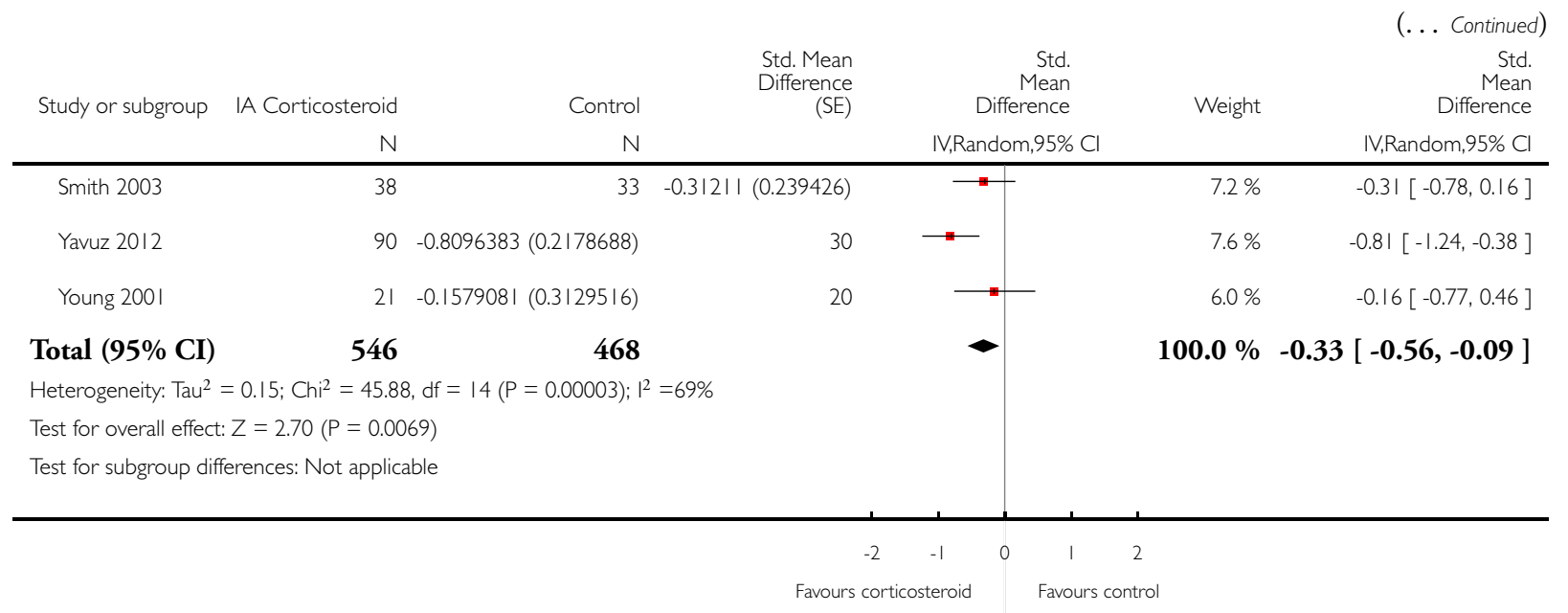

\section{Analysis 2.2. Comparison 2 Function, Outcome 2 Function - Timepoints.}

Review: Intra-articular corticosteroid for knee osteoarthritis

Comparison: 2 Function

Outcome: 2 Function - Timepoints

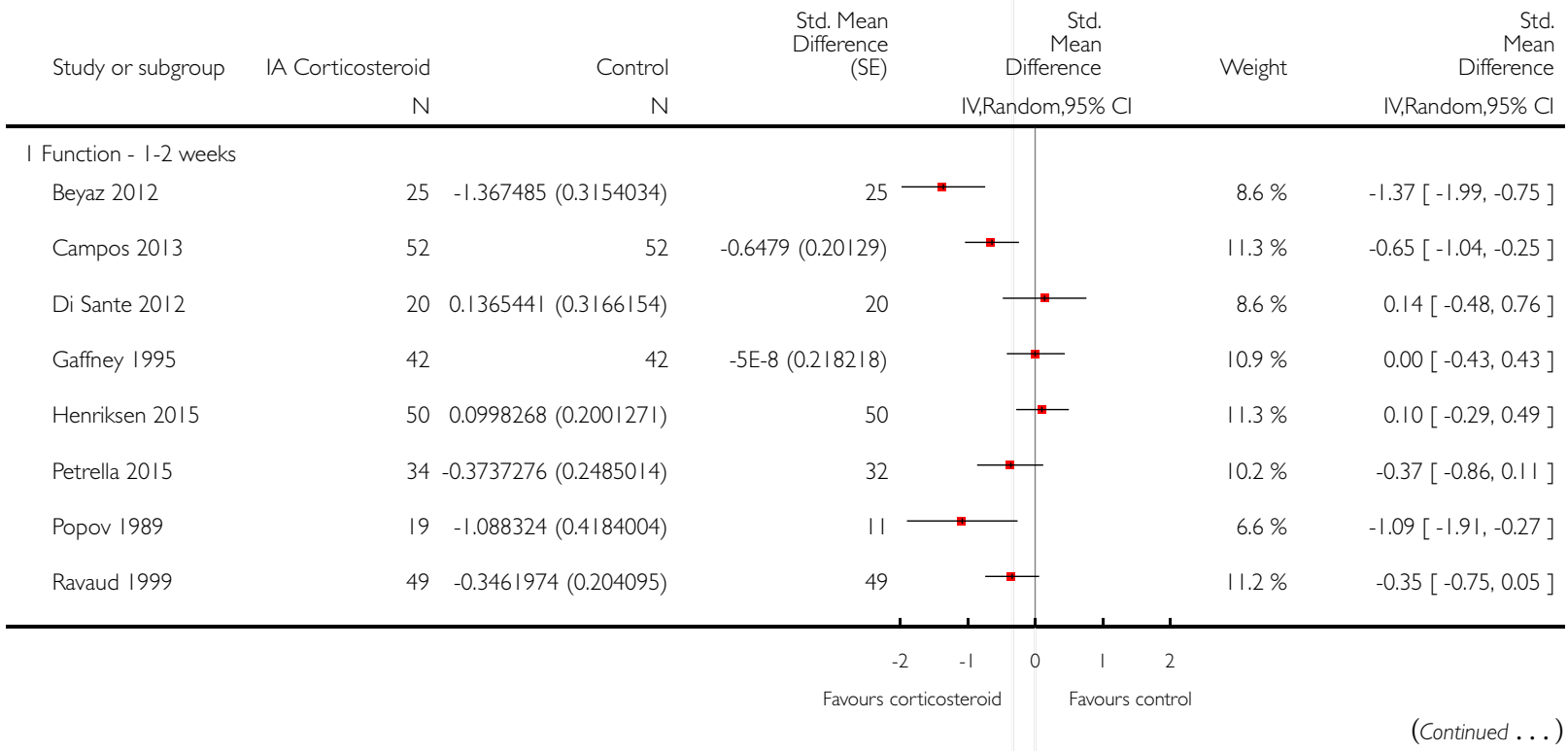

Intra-articular corticosteroid for knee osteoarthritis (Review) 


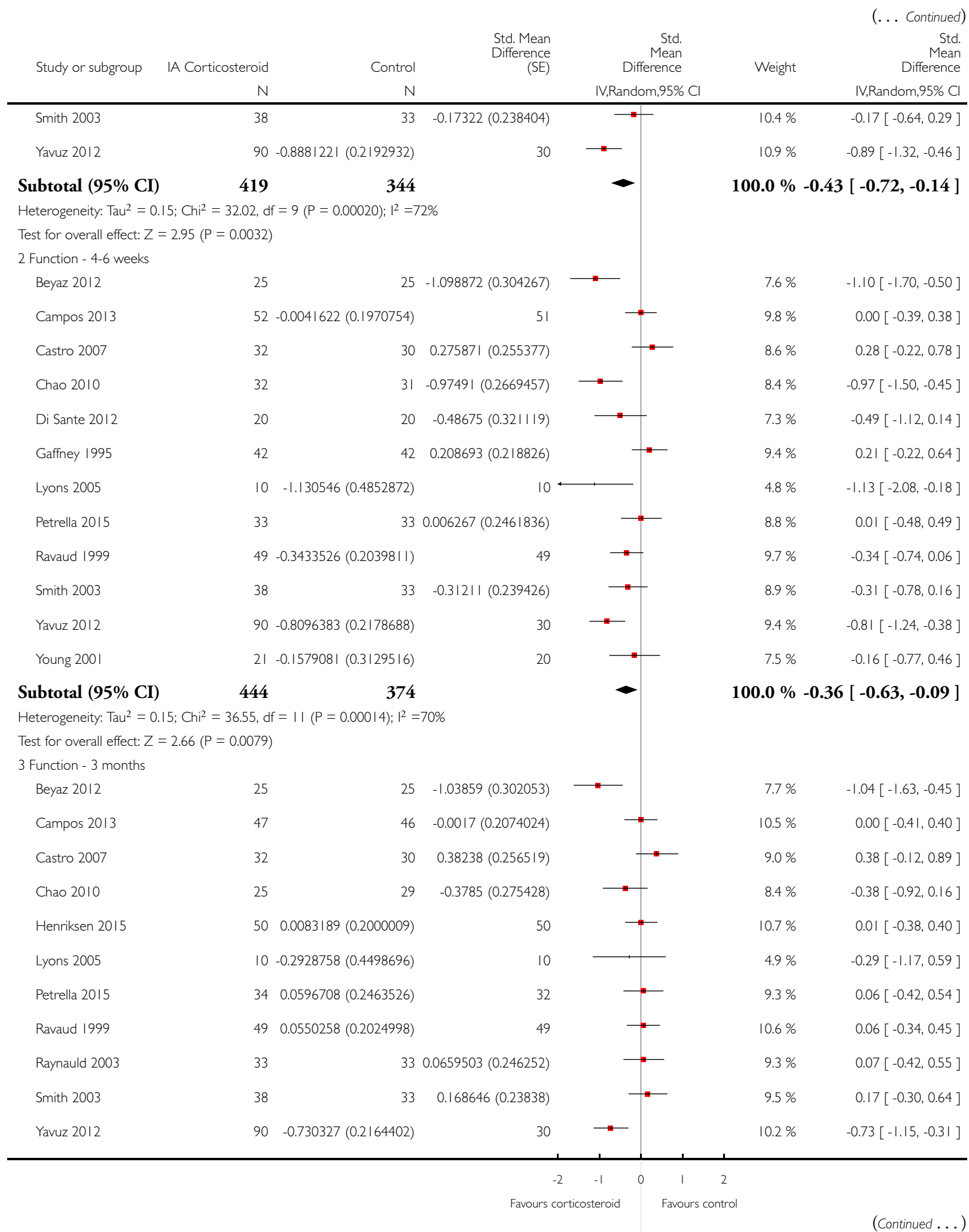

Intra-articular corticosteroid for knee osteoarthritis (Review) 


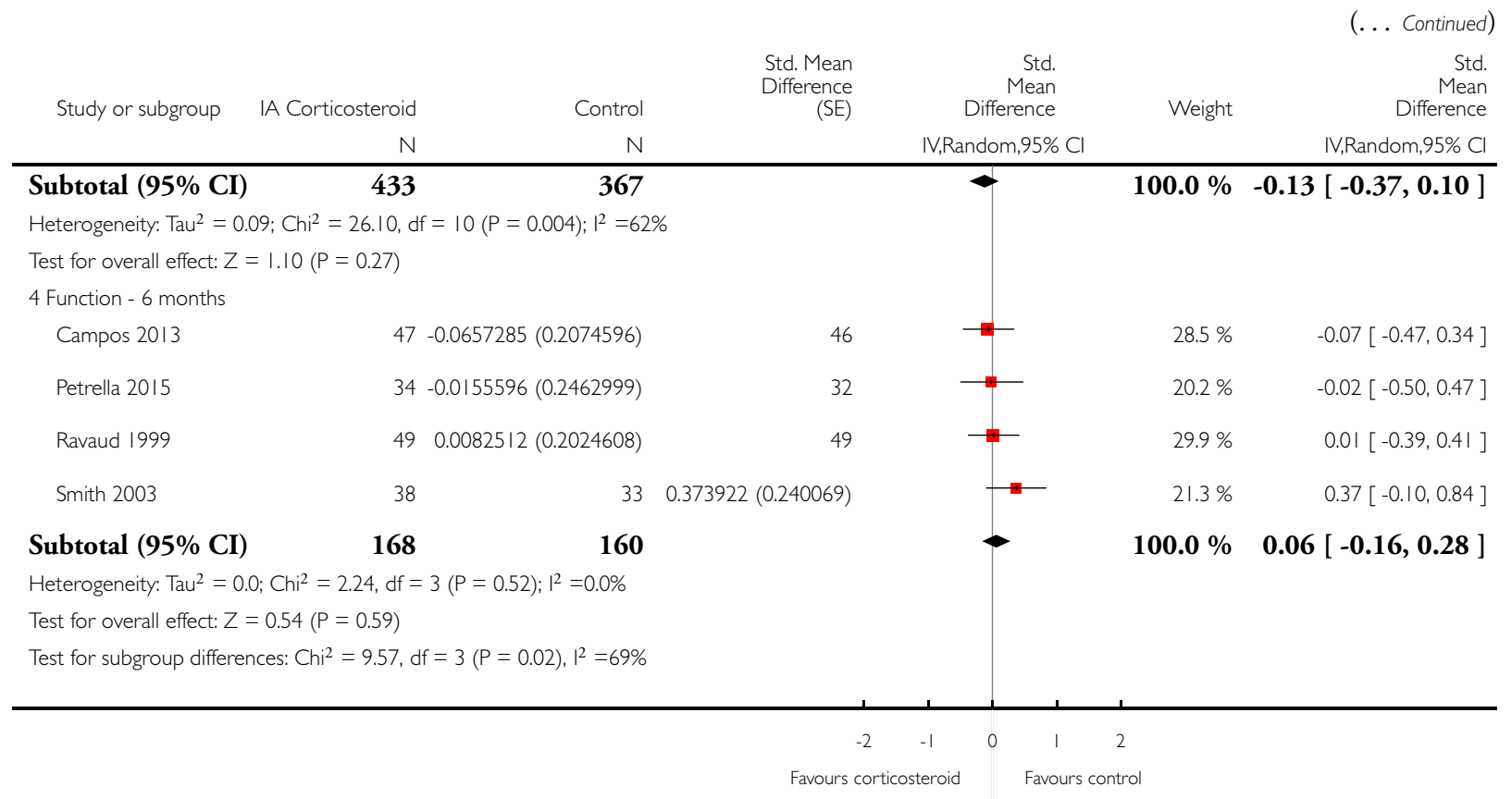

\section{Analysis 3.I. Comparison 3 Quality of life, Outcome I Quality of life - Main.}

Review: Intra-articular corticosteroid for knee osteoarthritis

Comparison: 3 Quality of life

Outcome: I Quality of life - Main

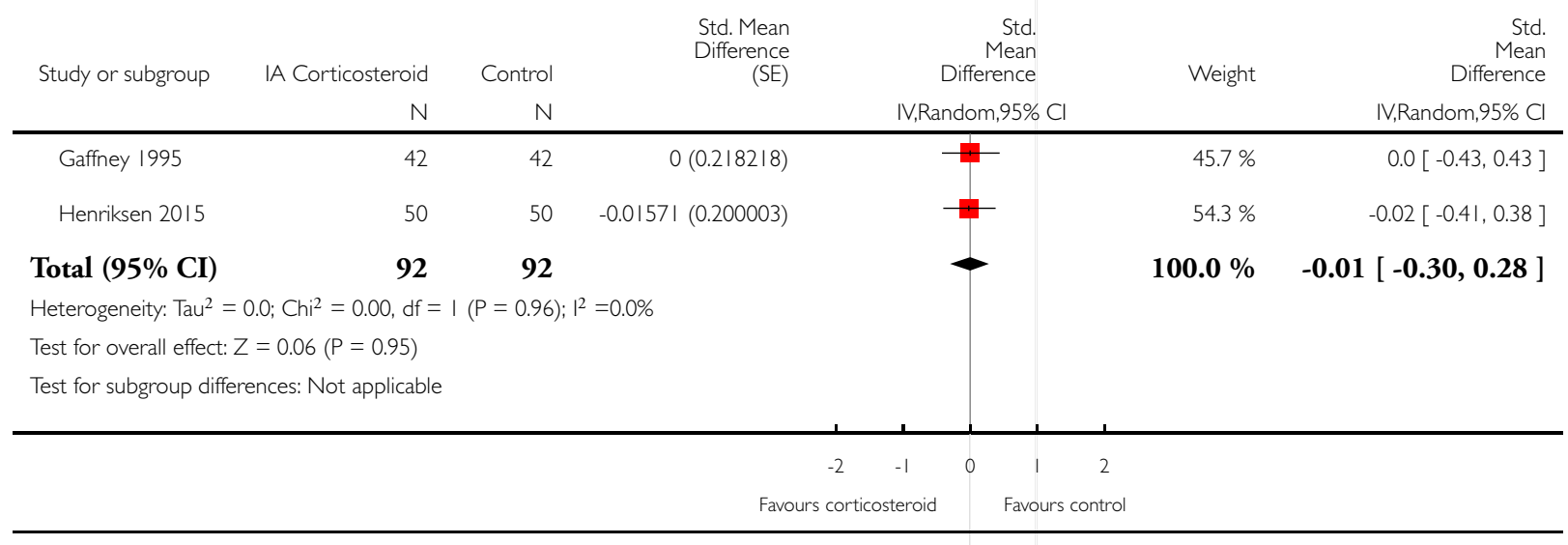

Intra-articular corticosteroid for knee osteoarthritis (Review)

Copyright @ 2015 The Cochrane Collaboration. Published by John Wiley \& Sons, Ltd. 
Analysis 4.I. Comparison 4 Number of participants experiencing any adverse event, Outcome I Number of participants experiencing any adverse event - Main.

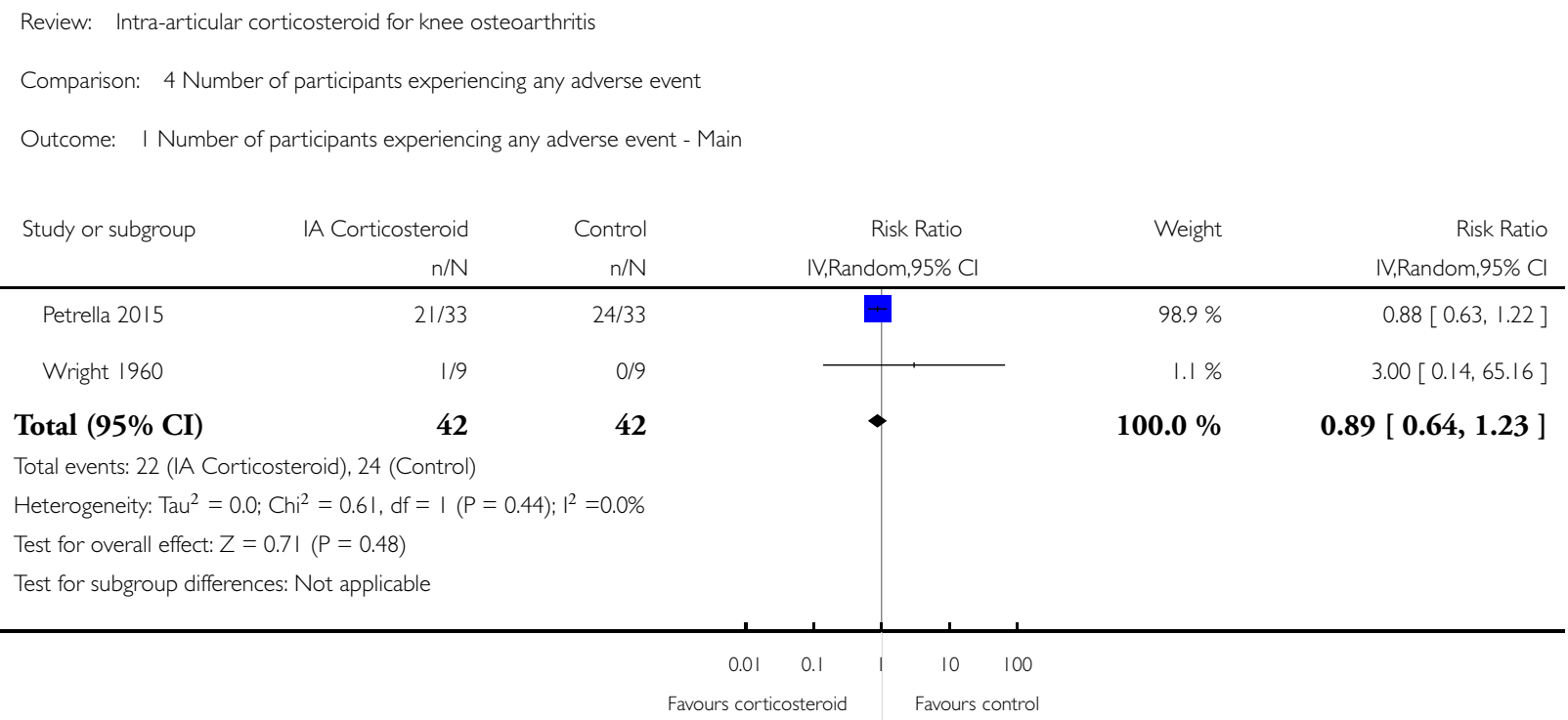


Analysis 5.I. Comparison 5 Number of participants who withdraw because of adverse events, Outcome I Number of participants who with draw because of adverse events -Main.

Review: Intra-articular corticosteroid for knee osteoarthritis

Comparison: 5 Number of participants who withdraw because of adverse events

Outcome: I Number of participants who with draw because of adverse events -Main

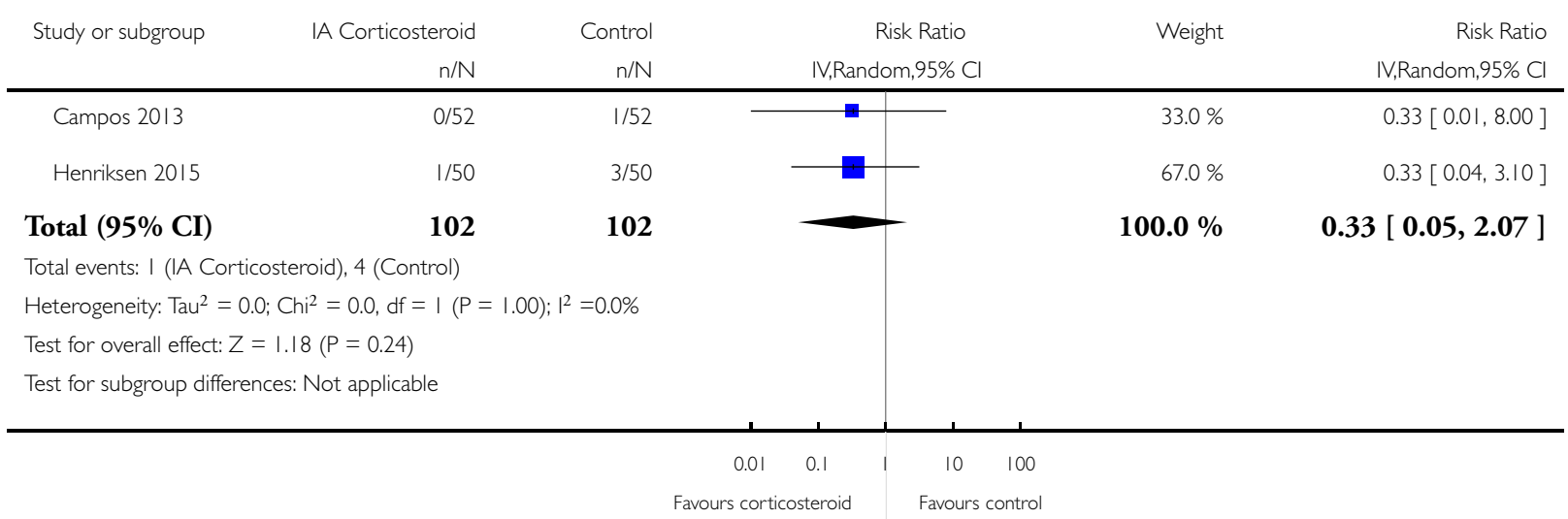


Analysis 6.I. Comparison 6 Number of participants experiencing any serious adverse event, Outcome I Number of participants experiencing any serious adverse event - Main.

Review: Intra-articular corticosteroid for knee osteoarthritis

Comparison: 6 Number of participants experiencing any serious adverse event

Outcome: I Number of participants experiencing any serious adverse event - Main

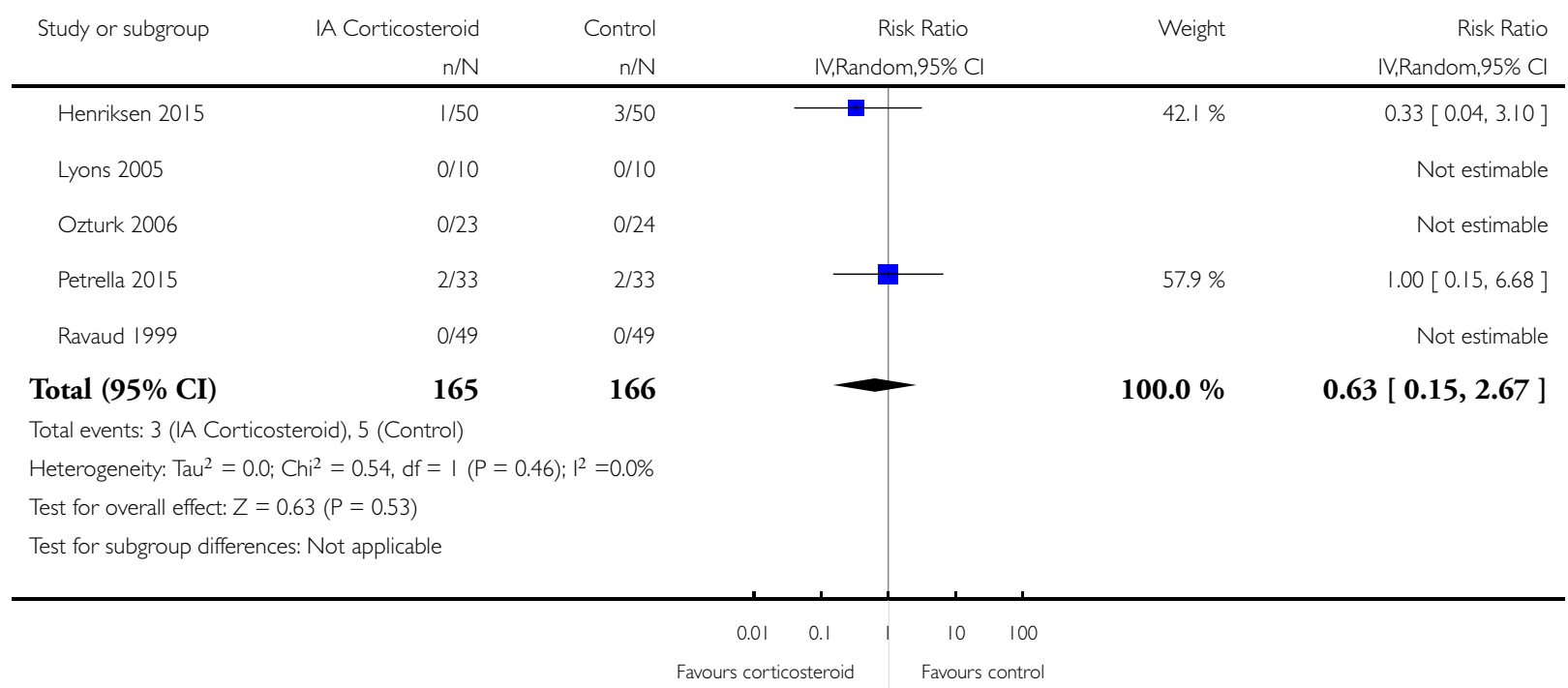




\section{Analysis 7.I. Comparison 7 Joint space narrowing, Outcome I Joint space narrowing - Main.}

Review: Intra-articular corticosteroid for knee osteoarthritis

Comparison: 7 Joint space narrowing

Outcome: I Joint space narrowing - Main

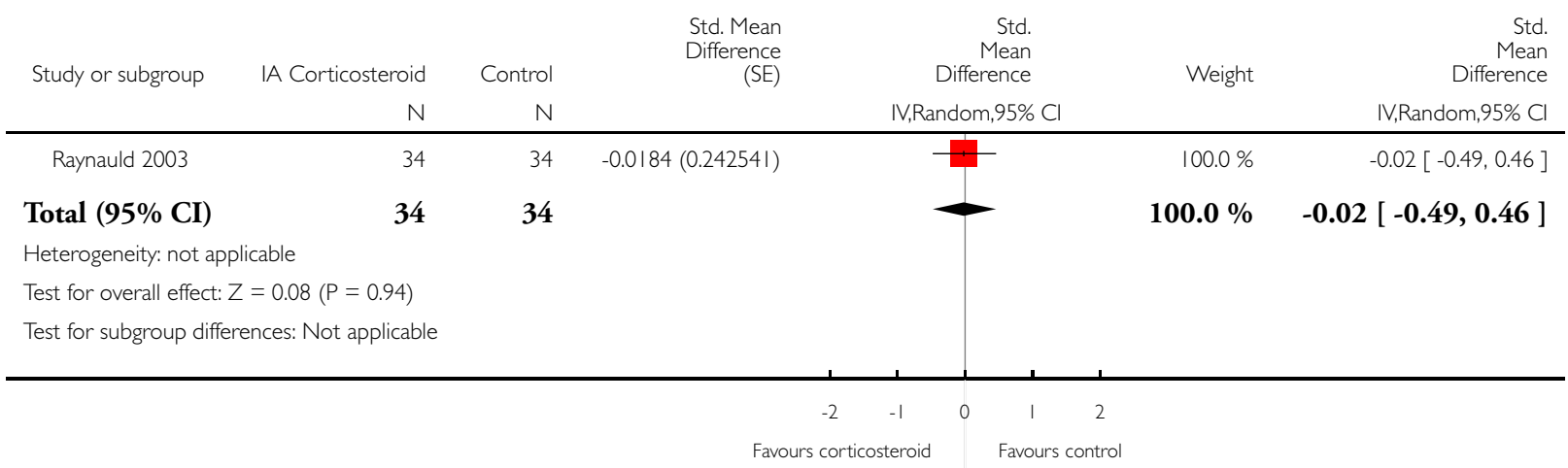

\section{A D DITIONAL TABLES}

Table 1. Stratified analyses: Pain

\begin{tabular}{|c|c|c|c|c|c|c|}
\hline Variable & $\begin{array}{l}\text { Number of } \\
\text { studies }\end{array}$ & $\begin{array}{l}\mathrm{N} \text { of partici- } \\
\text { pants corticos- } \\
\text { teroids }\end{array}$ & $\begin{array}{l}\mathrm{N} \text { of partici- } \\
\text { pants control }\end{array}$ & $\begin{array}{l}\text { Pain intensity } \\
\text { SMD }(95 \% \text { CI })\end{array}$ & $\begin{array}{l}\text { Heterogeneity I } \\
2(\%)\end{array}$ & P value* \\
\hline All trials & 26 & 922 & 827 & $\begin{array}{l}-0.40(-0.58 \text { to }- \\
0.22)\end{array}$ & $68 \%$ & \\
\hline \multicolumn{6}{|c|}{ Allocation concealment } & 0.15 \\
\hline Adequate & 2 & 88 & 83 & $\begin{array}{l}-0.16(-0.46 \text { to } 0 . \\
14)\end{array}$ & $0 \%$ & \\
\hline $\begin{array}{l}\text { Inadequate or } \\
\text { unclear }\end{array}$ & 24 & 834 & 744 & $\begin{array}{l}-0.42(-0.62 \text { to }- \\
0.22)\end{array}$ & $69 \%$ & \\
\hline \multicolumn{6}{|c|}{ Blinding of participants } & 0.64 \\
\hline Adequate & 6 & 220 & 218 & $\begin{array}{l}-0.34(-0.61 \text { to }- \\
0.06)\end{array}$ & $49 \%$ & \\
\hline $\begin{array}{l}\text { Inadequate or } \\
\text { unclear }\end{array}$ & 20 & 702 & 609 & $\begin{array}{l}-0.42(-0.65 \text { to }- \\
0.19)\end{array}$ & $72 \%$ & \\
\hline
\end{tabular}


Table 1. Stratified analyses: Pain (Continued)

\begin{tabular}{|c|c|c|c|c|c|c|}
\hline \multicolumn{6}{|c|}{ Blinding of therapists } & \multirow[t]{2}{*}{0.45} \\
\hline Adequate & 3 & 92 & 92 & $\begin{array}{l}-0.24(-0.66 \text { to } 0 . \\
17)\end{array}$ & $44 \%$ & \\
\hline $\begin{array}{l}\text { Inadequate or } \\
\text { unclear }\end{array}$ & 23 & 830 & 735 & $\begin{array}{l}-0.42(-0.62 \text { to }- \\
0.22)\end{array}$ & $70 \%$ & \\
\hline \multicolumn{6}{|c|}{ Intention-to-treat analysis } & 0.29 \\
\hline Yes & 9 & 236 & 233 & $\begin{array}{l}-0.26(-0.57 \text { to } 0 . \\
06)\end{array}$ & $59 \%$ & \\
\hline No or unclear & 17 & 686 & 594 & $\begin{array}{l}-0.47(-0.69 \text { to }- \\
0.24)\end{array}$ & $71 \%$ & \\
\hline \multicolumn{6}{|c|}{ Type of control intervention } & 0.08 \\
\hline Sham injection & 19 & 614 & 526 & $\begin{array}{l}-0.50(-0.72 \text { to }- \\
0.28)\end{array}$ & $65 \%$ & \\
\hline No intervention & 7 & 284 & 280 & $\begin{array}{l}-0.18(-0.47 \text { to } 0 . \\
11)\end{array}$ & $63 \%$ & \\
\hline \multicolumn{6}{|c|}{ Funding independent of industry } & 0.80 \\
\hline Yes & 11 & 341 & 333 & $\begin{array}{l}-0.37(-0.55 \text { to }- \\
0.18)\end{array}$ & $26 \%$ & \\
\hline No or unclear & 15 & 581 & 494 & $\begin{array}{l}-0.41(-0.70 \text { to }- \\
0.12)\end{array}$ & $78 \%$ & \\
\hline \multicolumn{6}{|l|}{ Trial size } & 0.05 \\
\hline $\begin{array}{l}\geq 50 \text { per trial } \\
\text { group }\end{array}$ & 3 & 205 & 204 & $\begin{array}{l}-0.13(-0.37 \text { to } 0 . \\
12)\end{array}$ & $34 \%$ & \\
\hline $\begin{array}{l}<50 \text { per trial } \\
\text { group }\end{array}$ & 23 & 717 & 623 & $\begin{array}{l}-0.44(-0.65 \text { to }- \\
0.24)\end{array}$ & $67 \%$ & \\
\hline \multicolumn{6}{|l|}{ Trial size } & 0.013 \\
\hline $\begin{array}{l}\geq 100 \text { per trial } \\
\text { group }\end{array}$ & 1 & 103 & 103 & $\begin{array}{l}0.00(-0.27 \text { to } 0 . \\
27)\end{array}$ & N/A & \\
\hline $\begin{array}{l}<100 \text { per trial } \\
\text { group }\end{array}$ & 25 & 819 & 724 & $\begin{array}{l}-0.42(-0.61 \text { to }- \\
0.23)\end{array}$ & $66 \%$ & \\
\hline
\end{tabular}


Table 1. Stratified analyses: Pain (Continued)

\begin{tabular}{|c|c|c|c|c|c|c|}
\hline \multicolumn{6}{|l|}{ Publication type } & \multirow[t]{2}{*}{0.93} \\
\hline $\begin{array}{l}\text { Full journal arti- } \\
\text { cle }\end{array}$ & 22 & 785 & 706 & $\begin{array}{l}-0.40(-0.61 \text { to }- \\
0.20)\end{array}$ & $70 \%$ & \\
\hline $\begin{array}{l}\text { Other type or } \\
\text { unpublished ma- } \\
\text { terial }\end{array}$ & 4 & 137 & 121 & $\begin{array}{l}-0.38(-0.84 \text { to }- \\
0.08)\end{array}$ & $65 \%$ & \\
\hline \multicolumn{6}{|c|}{ Ultrasound guidance of injections } & 0.71 \\
\hline Yes & 2 & 70 & 70 & $\begin{array}{l}-0.62(-1.83 \text { to } 0 . \\
58)\end{array}$ & $89 \%$ & \\
\hline No or unclear & 24 & 852 & 757 & $\begin{array}{l}-0.39(-0.57 \text { to }- \\
0.20)\end{array}$ & $67 \%$ & \\
\hline \multicolumn{6}{|c|}{ Use of local anaesthetic } & 0.41 \\
\hline Yes & 5 & 172 & 157 & $\begin{array}{l}-0.55(-0.93 \text { to }- \\
0.16)\end{array}$ & $62 \%$ & \\
\hline No or unclear & 21 & 750 & 670 & $\begin{array}{l}-0.36(-0.57 \text { to }- \\
0.15)\end{array}$ & $70 \%$ & \\
\hline \multicolumn{6}{|c|}{ Concomitant viscosupplementation } & 0.08 \\
\hline Yes & 4 & 129 & 127 & $\begin{array}{l}-0.16(-0.42 \text { to } 0 . \\
09)\end{array}$ & $4 \%$ & \\
\hline No or unclear & 22 & 793 & 700 & $\begin{array}{l}-0.46(-0.67 \text { to }- \\
0.25)\end{array}$ & $71 \%$ & \\
\hline \multicolumn{6}{|c|}{ Concomitant joint lavage } & $\leq 0.001$ \\
\hline Yes & 4 & 197 & 187 & $\begin{array}{l}-0.06(-0.26 \text { to } 0 . \\
15)\end{array}$ & $0 \%$ & \\
\hline No or unclear & 26 & 725 & 640 & $\begin{array}{l}-0.57(-0.78 \text { to }- \\
0.35)\end{array}$ & $72 \%$ & \\
\hline \multicolumn{6}{|c|}{ Use of crystalline preparation } & 0.82 \\
\hline Yes & 18 & 623 & 562 & $\begin{array}{l}-0.47(-0.69 \text { to }- \\
0.24)\end{array}$ & $72 \%$ & \\
\hline No or unclear & 12 & 299 & 265 & $\begin{array}{l}-0.52(-0.90 \text { to }- \\
0.14)\end{array}$ & $76 \%$ & \\
\hline
\end{tabular}


Table 1. Stratified analyses: Pain (Continued)

\begin{tabular}{llllll}
\hline \multicolumn{2}{l}{ Prednisolone equivalence dose } & & & 0.53 \\
\hline$\geq 50 \mathrm{mg}$ & 17 & 520 & 470 & $\begin{array}{l}-0.55(-0.85 \text { to }-80 \% \\
0.25)\end{array}$ \\
\hline$<50 \mathrm{mg}$ & 13 & 402 & 357 & $\begin{array}{l}-0.43(-0.66 \text { to }-56 \% \\
0.20)\end{array}$ \\
\hline
\end{tabular}

Number of randomised comparisons are shown in "number of studies" for stratified analyses according to use of lavage as co-intervention, crystalline preparation, prednisolone equivalence. ${ }^{*} \mathrm{P}$ value for interaction. N/A: not available.

CI: confidence interval

SMD: standardised mean difference

Table 2. Stratified analyses: Function

\begin{tabular}{|c|c|c|c|c|c|c|}
\hline Variable & $\begin{array}{l}\text { Number of } \\
\text { studies }\end{array}$ & $\begin{array}{l}\mathrm{N} \text { of partici- } \\
\text { pants corticos- } \\
\text { teroids }\end{array}$ & $\begin{array}{l}\mathrm{N} \text { of partici- } \\
\text { pants control }\end{array}$ & $\begin{array}{l}\text { Function SMD } \\
(95 \% \mathrm{CI})\end{array}$ & $\begin{array}{l}\text { Heterogeneity I } \\
{ }^{2}(\%)\end{array}$ & P value* \\
\hline All trials & 15 & 546 & 468 & $\begin{array}{l}-0.33(-0.56 \text { to }- \\
0.09)\end{array}$ & $69 \%$ & \\
\hline \multicolumn{6}{|c|}{ Allocation concealment } & 0.25 \\
\hline Adequate & 2 & 88 & 83 & $\begin{array}{l}-0.09(-0.49 \text { to } 0 . \\
32)\end{array}$ & $43 \%$ & \\
\hline $\begin{array}{l}\text { Inadequate or } \\
\text { unclear }\end{array}$ & 13 & 458 & 385 & $\begin{array}{l}-0.37(-0.64 \text { to }- \\
0.10)\end{array}$ & $72 \%$ & \\
\hline \multicolumn{6}{|c|}{ Blinding of participants } & 0.97 \\
\hline Adequate & 5 & 201 & 199 & $\begin{array}{l}-0.32(-0.82 \text { to } 0 . \\
18)\end{array}$ & $83 \%$ & \\
\hline $\begin{array}{l}\text { Inadequate or } \\
\text { unclear }\end{array}$ & 10 & 345 & 269 & $\begin{array}{l}-0.33(-0.59 \text { to }- \\
0.07)\end{array}$ & $58 \%$ & \\
\hline \multicolumn{6}{|c|}{ Blinding of therapists } & 0.78 \\
\hline Adequate & 2 & 75 & 75 & $\begin{array}{l}-0.48(-1.65 \text { to } 0 . \\
70)\end{array}$ & $91 \%$ & \\
\hline $\begin{array}{l}\text { Inadequate or } \\
\text { unclear }\end{array}$ & 13 & 471 & 393 & $\begin{array}{l}-0.31(-0.55 \text { to }- \\
0.06)\end{array}$ & $66 \%$ & \\
\hline \multicolumn{6}{|c|}{ Intention-to-treat analysis } & 0.49 \\
\hline
\end{tabular}


Table 2. Stratified analyses: Function (Continued)

\begin{tabular}{|c|c|c|c|c|c|c|}
\hline Yes & 5 & 161 & 159 & $\begin{array}{l}-0.21(-0.59 \text { to } 0 . \\
17)\end{array}$ & $62 \%$ & \\
\hline No or unclear & 10 & 385 & 309 & $\begin{array}{l}-0.38(-0.69 \text { to }- \\
0.07)\end{array}$ & $73 \%$ & \\
\hline \multicolumn{6}{|c|}{ Type of control intervention } & 0.031 \\
\hline Sham injection & 11 & 409 & 334 & $\begin{array}{l}-0.45(-0.74 \text { to }- \\
0.15)\end{array}$ & $73 \%$ & \\
\hline No intervention & 4 & 137 & 134 & $\begin{array}{l}-0.01(-0.27 \text { to } 0 . \\
25)\end{array}$ & $13 \%$ & \\
\hline \multicolumn{6}{|c|}{ Funding independent of industry } & 0.73 \\
\hline Yes & 9 & 310 & 302 & $\begin{array}{l}-0.36(-0.66 \text { to }- \\
0.07)\end{array}$ & $68 \%$ & \\
\hline No or unclear & 6 & 236 & 166 & $\begin{array}{l}-0.27(-0.71 \text { to } 0 . \\
16)\end{array}$ & $76 \%$ & \\
\hline \multicolumn{6}{|l|}{ Trial size } & 0.023 \\
\hline $\begin{array}{l}\geq 50 \text { per trial } \\
\text { group }\end{array}$ & 2 & 102 & 101 & $\begin{array}{l}0.05(-0.23 \text { to } 0 . \\
32)\end{array}$ & $0 \%$ & \\
\hline $\begin{array}{l}<50 \text { per trial } \\
\text { group }\end{array}$ & 13 & 444 & 367 & $\begin{array}{l}-0.40(-0.67 \text { to }- \\
0.13)\end{array}$ & $70 \%$ & \\
\hline \multicolumn{6}{|l|}{ Trial size } & N/A \\
\hline $\begin{array}{l}\geq 100 \text { per trial } \\
\text { group }\end{array}$ & 0 & 0 & 0 & N/A & N/A & \\
\hline $\begin{array}{l}<100 \text { per trial } \\
\text { group }\end{array}$ & 15 & 546 & 468 & $\begin{array}{l}-0.33(-0.56 \text { to }- \\
0.09)\end{array}$ & $69 \%$ & \\
\hline \multicolumn{6}{|l|}{ Publication type } & 0.023 \\
\hline $\begin{array}{l}\text { Full journal arti- } \\
\text { cle }\end{array}$ & 14 & 514 & 438 & $\begin{array}{l}-0.37(-0.61 \text { to }- \\
0.13)\end{array}$ & $68 \%$ & \\
\hline $\begin{array}{l}\text { Other type or } \\
\text { unpublished ma- } \\
\text { terial }\end{array}$ & 1 & 32 & 30 & $\begin{array}{l}0.28(-0.22 \text { to } 0 . \\
78)\end{array}$ & N/A & \\
\hline \multicolumn{6}{|c|}{ Ultrasound guidance of injections } & 0.49 \\
\hline
\end{tabular}


Table 2. Stratified analyses: Function (Continued)

\begin{tabular}{|c|c|c|c|c|c|c|}
\hline Yes & 2 & 70 & 70 & $\begin{array}{l}-0.14(-0.70 \text { to } 0 . \\
43)\end{array}$ & $58 \%$ & \\
\hline No or unclear & 13 & 476 & 398 & $\begin{array}{l}-0.36(-0.62 \text { to }- \\
0.09)\end{array}$ & $71 \%$ & \\
\hline \multicolumn{6}{|c|}{ Use of local anaesthetic } & 0.34 \\
\hline Yes & 4 & 105 & 105 & $\begin{array}{l}-0.60(-1.25 \text { to } 0 . \\
05)\end{array}$ & $78 \%$ & \\
\hline No or unclear & 11 & 441 & 363 & $\begin{array}{l}-0.25(-0.51 \text { to } 0 . \\
00)\end{array}$ & $68 \%$ & \\
\hline \multicolumn{6}{|c|}{ Concomitant viscosupplementation } & 0.06 \\
\hline Yes & 2 & 85 & 84 & $\begin{array}{l}-0.00(-0.30 \text { to } 0 . \\
30)\end{array}$ & $0 \%$ & \\
\hline No or unclear & 13 & 461 & 384 & $\begin{array}{l}-0.39(-0.66 \text { to }- \\
0.12)\end{array}$ & $72 \%$ & \\
\hline \multicolumn{6}{|c|}{ Concomitant joint lavage } & 0.18 \\
\hline Yes & 3 & 94 & 84 & $\begin{array}{l}-0.13(-0.55 \text { to } 0 . \\
28)\end{array}$ & $48 \%$ & \\
\hline No or unclear & 16 & 452 & 384 & $\begin{array}{l}-0.46(-0.71 \text { to }- \\
0.21)\end{array}$ & $70 \%$ & \\
\hline \multicolumn{6}{|c|}{ Use of crystalline preparation } & 0.66 \\
\hline Yes & 12 & 365 & 319 & $\begin{array}{l}-0.37(-0.66 \text { to }- \\
0.08)\end{array}$ & $73 \%$ & \\
\hline No or unclear & 7 & 181 & 149 & $\begin{array}{l}-0.47(-0.83 \text { to }- \\
0.11)\end{array}$ & $61 \%$ & \\
\hline \multicolumn{6}{|c|}{ Prednisolone equivalence dose } & 0.16 \\
\hline$\geq 50 \mathrm{mg}$ & 12 & 328 & 277 & $\begin{array}{l}-0.52(-0.83 \text { to }- \\
0.20)\end{array}$ & $74 \%$ & \\
\hline$<50 \mathrm{mg}$ & 7 & 218 & 191 & $\begin{array}{l}-0.22(-0.48 \text { to } 0 . \\
05)\end{array}$ & $47 \%$ & \\
\hline
\end{tabular}

Number of randomised comparisons are shown in "number of studies" for stratified analyses according to use of lavage as co-intervention, crystalline preparation, prednisolone equivalence. ${ }^{*} \mathrm{P}$ value for interaction. N/A: not available. 
CI: confidence interval

SMD: standardised mean difference

A P P E N D I C ES

\section{Appendix I. MEDLINE and PubMed search strategies}

\begin{tabular}{|c|c|c|c|c|c|}
\hline MEDLINE* & & & PubMed $\dagger$ & & \\
\hline Search line & Search Terms & No. citations & Search line & Search Terms & No. citations \\
\hline 1 & $\begin{array}{l}{ }^{*} \text { Adrenal Cortex } \\
\text { Hormones/ or }{ }^{*} 17 \text { - } \\
\text { Hydroxycorticos- } \\
\text { teroids/ or }{ }^{*} 11 \text {-Hy- } \\
\text { droxycorticosteroids/ } \\
\text { or }{ }^{*} \text { Hydroxycorticos- } \\
\text { teroids/ or }{ }^{*} \text { Ketos- } \\
\text { teroids/ or }{ }^{*} 17-\text { Ke- } \\
\text { tosteroids/ or }{ }^{*} \text { An- } \\
\text { drostenedione/ } \\
\text { or }{ }^{*} \text { Prednisolone/ or } \\
{ }^{*} \text { Glucocorticoids/ or } \\
{ }^{*} \text { Triamcinolone Ace- } \\
\text { tonide/ or }{ }^{*} \text { Hydro- } \\
\text { cortisone/ or }{ }^{*} \text { corti- } \\
\text { sone/ }\end{array}$ & 104853 & 1 & 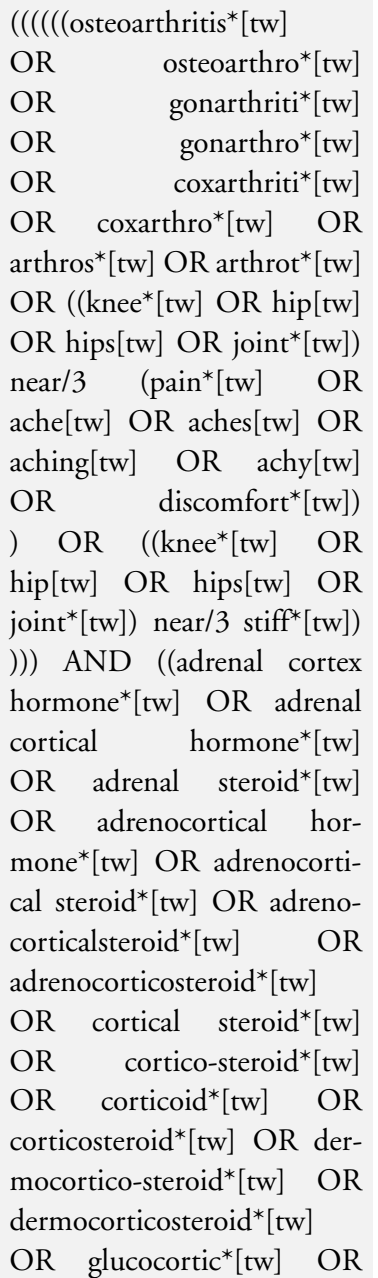 & \\
\hline
\end{tabular}




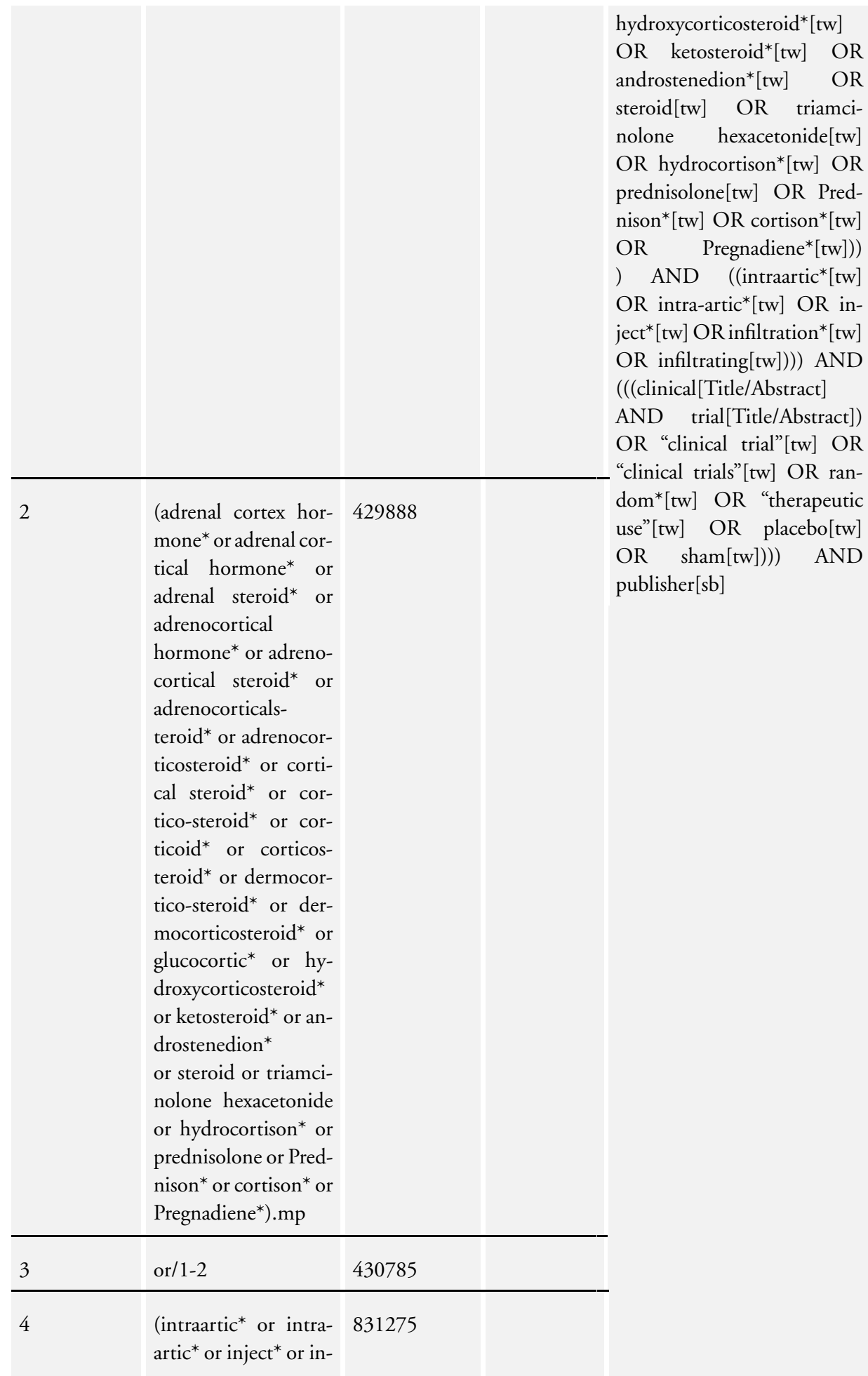

Intra-articular corticosteroid for knee osteoarthritis (Review) 


\begin{tabular}{|c|c|c|}
\hline & $\begin{array}{l}\text { filtration* or infiltrat- } \\
\text { ing).mp }\end{array}$ & \\
\hline 5 & exp osteoarthritis/ & 44274 \\
\hline 6 & $\begin{array}{l}\text { (osteoarthriti\$ or os- } \\
\text { teoarthro\$ } \\
\text { or gonarthriti\$ or go- } \\
\text { narthro\$ or } \\
\text { coxarthriti\$ or } \\
\text { coxarthro\$).ti,ab,sh }\end{array}$ & 62668 \\
\hline 7 & $\begin{array}{l}\text { (arthros\$ or arthrot\$) } \\
\text {.ti,ab. }\end{array}$ & 26671 \\
\hline 8 & $\begin{array}{l}\text { ( }(\text { knee} \$ \text { or hip\$ or } \\
\text { joint\$) adj3 (pain\$ or } \\
\text { ach\$ or discomfort\$) } \\
\text { ).ti,ab }\end{array}$ & 20156 \\
\hline 9 & $\begin{array}{l}((\text { knee\$ or hip\$ or } \\
\text { joint\$) adj3 stiff\$).ti, } \\
\text { ab. }\end{array}$ & 2914 \\
\hline 10 & or/5-9 & 101715 \\
\hline 11 & $\begin{array}{l}\text { (randomized con- } \\
\text { trolled trial or con- } \\
\text { trolled clinical trial). } \\
\text { pt }\end{array}$ & 465958 \\
\hline 12 & $\begin{array}{l}\text { (randomized or } \\
\text { placebo or randomly } \\
\text { or groups or trial).ab. }\end{array}$ & 1916245 \\
\hline 13 & drug therapy.fs. & 1728855 \\
\hline 14 & or/11-13 & 3430383 \\
\hline 15 & random*.ti,ab. & 739136 \\
\hline 16 & or/14-15 & 3575985 \\
\hline 17 & and $/ 3-4,10,16$ & 766 \\
\hline 18 & $\begin{array}{l}\text { exp animals/ not hu- } \\
\text { mans.sh. }\end{array}$ & 3974624 \\
\hline 19 & 17 not 18 & 719 \\
\hline
\end{tabular}




$20 \quad \begin{aligned} & \text { remove } \\ & \text { from } 19\end{aligned}$ duplicates $\mathbf{7 1 3}$

* Search performed at $02^{\text {nd }}$ of February 2015, using the following database in OvidSP: Ovid MEDLINE(R) In-Process \& Other NonIndexed Citations and Ovid MEDLINE(R) 1946 to Present

$\dagger$ Top-up search in PubMed (http://www.ncbi.nlm.nih.gov/pubmed) at $03^{r d}$ Februari 2015, to retrieve citations not yet indexed in OvidSP MEDLINE databases

\section{Appendix 2. EMBASE and CENTRAL search strategies}

\begin{tabular}{|c|c|c|c|c|c|}
\hline \multicolumn{2}{|l|}{ EMBASE* } & \multirow[b]{2}{*}{ No. citations } & \multicolumn{2}{|l|}{ CENTRAL $\dagger$} & \multirow[b]{2}{*}{ No. citations } \\
\hline Search line & Search Terms & & Search line & Search Terms & \\
\hline \multirow[t]{3}{*}{1} & \multirow{3}{*}{$\begin{array}{l}\text { *Adrenal Cortex } \\
\text { Hormones/ } \\
\text { or }{ }^{*} 17-H y d r o x y- \\
\text { corticosteroids/ } \\
\text { or }{ }^{*} 11 \text {-Hydroxy- } \\
\text { corticosteroids/ } \\
\text { or }{ }^{*} \text { Hydroxycor- } \\
\text { ticosteroids/ or } \\
{ }^{*} \text { Ketosteroids/ or } \\
{ }^{*} 17-\text { Ketos- } \\
\text { teroids/ or }{ }^{*} \text { An- } \\
\text { drostenedione/ or } \\
{ }^{*} \text { Prednisolone/ or } \\
{ }^{*} \text { Glucocor- } \\
\text { ticoids/ or }{ }^{*} \text { Tri- } \\
\text { amcinolone Ace- } \\
\text { tonide/ or }{ }^{*} \mathrm{Hy}- \\
\text { drocortisone/ or } \\
{ }^{*} \text { cortisone/ }\end{array}$} & 191907 & $\# 1$ & $\begin{array}{l}\text { MeSH descrip- } \\
\text { tor: [Adrenal Cortex } \\
\text { Hormones] explode } \\
\text { all trees }\end{array}$ & 11438 \\
\hline & & & $\# 2$ & $\begin{array}{l}\mathrm{MeSH} \text { descrip- } \\
\text { tor: [Prednisolone] } \\
\text { explode all trees }\end{array}$ & 3470 \\
\hline & & & $\# 3$ & $\begin{array}{l}\text { MeSH } \\
\text { descriptor: [Hydro- } \\
\text { cortisone] explode } \\
\text { all trees }\end{array}$ & 4565 \\
\hline 2 & $\begin{array}{l}\text { (adrenal } \\
\text { cortex hormone* } \\
\text { or adrenal corti- } \\
\text { cal hormone* or } \\
\text { adrenal steroid* } \\
\text { or adrenocortical } \\
\text { hor- } \\
\text { mone* or adreno- } \\
\text { cortical steroid* } \\
\text { or adrenocortical- } \\
\text { s- } \\
\text { teroid* or adreno- }\end{array}$ & 871195 & $\# 4$ & $\begin{array}{l}\text { MeSH descrip- } \\
\text { tor: [Triamcinolone } \\
\text { Acetonide] explode } \\
\text { all trees }\end{array}$ & 603 \\
\hline
\end{tabular}


corticosteroid* or cortical steroid* or corticosteroid* or corticoid* or corticosteroid* or dermocortico-steroid* or dermocorticosteroid* or glucocortic* or hydroxycor-

ticosteroid* or ketosteroid* or androstenedion* or steroid or triamcinolone hexacetonide or hydrocortison* or prednisolone or Prednison* or corti-

* $n$

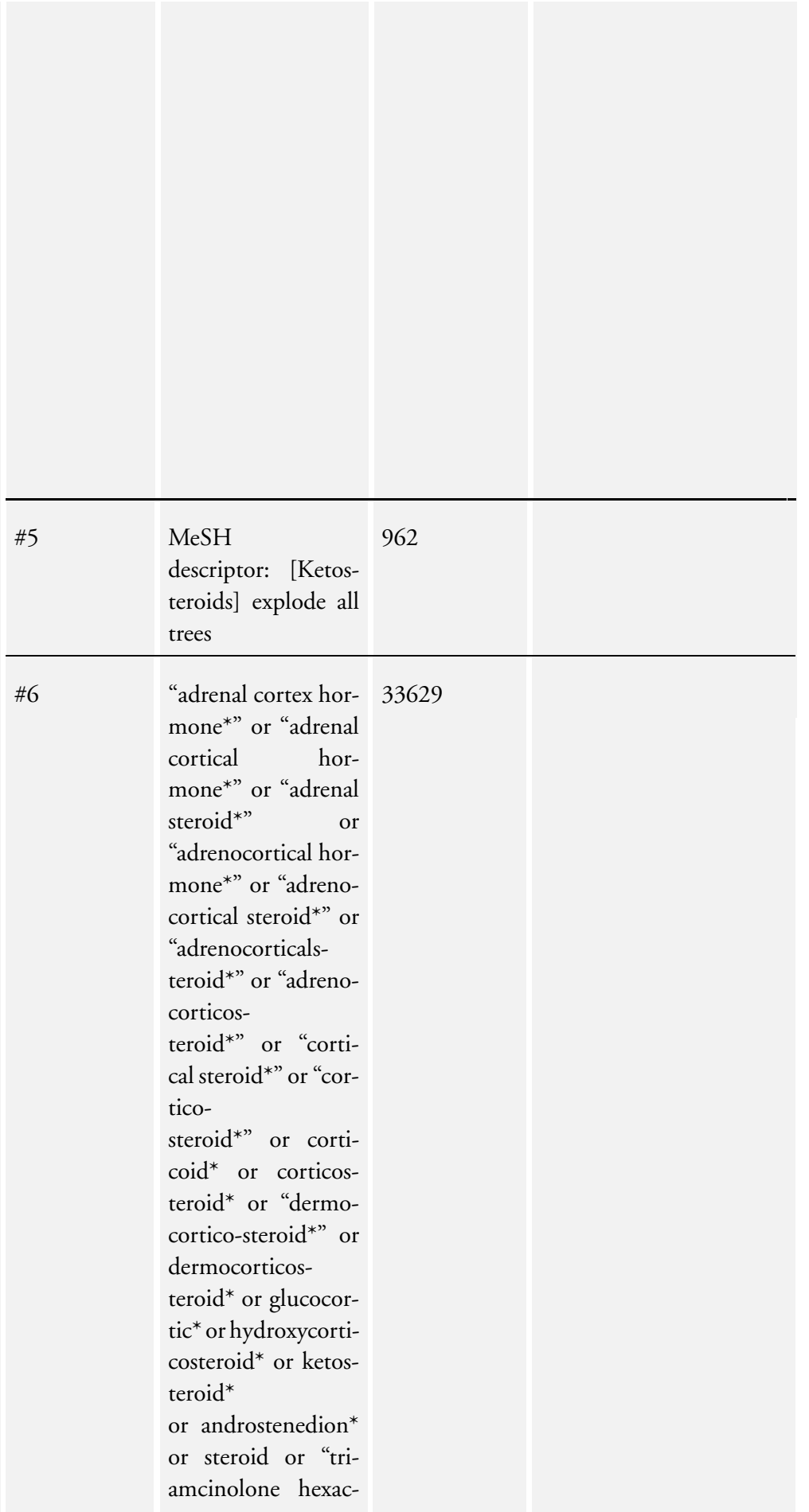

Intra-articular corticosteroid for knee osteoarthritis (Review) 


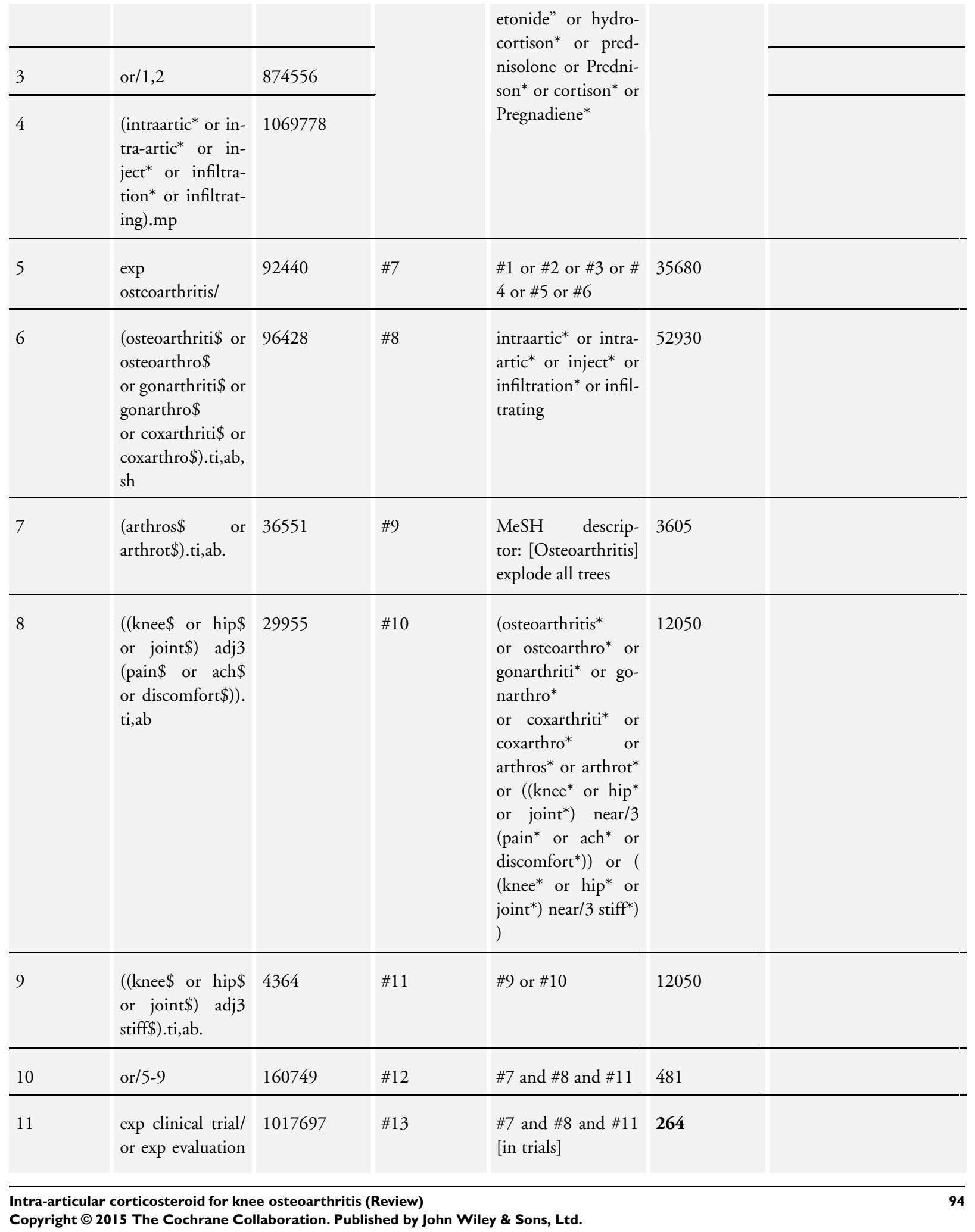


studies/

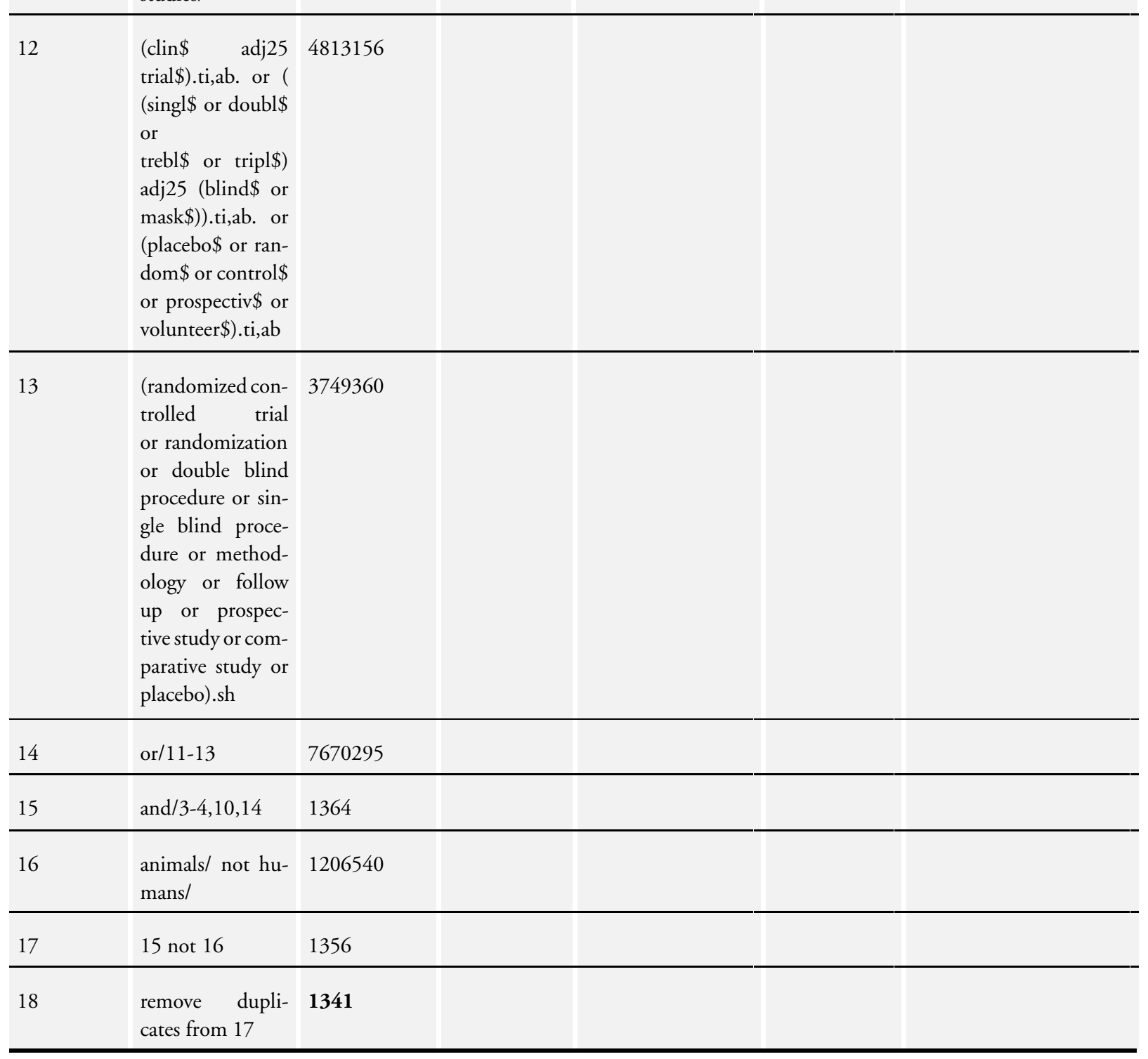

* Search performed at $03^{r d}$ of February 2015, using the following database in OvidSP: Embase Weekly Alerts 2014/07/28-Present, Embase Classic+Embase 1947 to Present

$\dagger$ Search performed at $03^{\text {rd }}$ of February 2015, using the Cochrane Library of the publisher Wiley at http://onlinelibrary.wiley.com/ cochranelibrary/search. 


\section{WHAT'S NEW}

Last assessed as up-to-date: 3 February 2015.

\begin{tabular}{l|l|l}
\hline Date & Event & Description \\
\hline 2 November 2015 & Amended & Typo corrected. \\
\hline
\end{tabular}

\section{H I S T O R Y}

Protocol first published: Issue 1, 1998

Review first published: Issue 2, 2005

\begin{tabular}{l|ll}
\hline Date & Event & Description \\
\hline 2 September 2015 & New citation required and conclusions have changed & The review has been updated since last version of 2006. \\
\hline
\end{tabular}

\section{CONTRIBUTIONS OF AUTHORS}

Protocol completion: Jüni, Rutjes, Reichenbach, da Costa.

Acquisition of data: Hari, Rutjes, Fischer, Silletta, da Costa.

Analysis and interpretation of data: Jüni, Hari, Reichenbach, da Costa.

Manuscript preparation: Jüni, Hari, da Costa.

Statistical analysis: Jüni, da Costa.

\section{DECLARATIONS OF INTEREST}

Peter Jüni: none

Roman Hari: none

Anne WS Rutjes: none

Roland Fischer: none

Maria G Silletta: none

Stephan Reichenbach: none

Bruno R da Costa: none 


\section{SOURCES OF SUPPORT}

\section{Internal sources}

- No sources of support supplied

\section{External sources}

- NIHR Cochrane Direct Commmission Incentive Award, UK.

This review was supported by a grant from the NIHR, UK (NIHR Cochrane Direct Commmission Incentive Award)

\section{DIFFERENCESBETWEEN PROTOCOLANDREVIEW}

\section{Types of studies}

In the previous version of this Cochrane Review, only RCTs were eligible for inclusion, while in the present review update both RCTs and quasi-RCTs were eligible.

\section{Types of interventions}

In the previous review version, control interventions were both sham intra-articular corticosteroid and active interventions (joint lavage, intra-articular hyaluronan/hylan, and other intra-articular corticosteroids). In the present review update, the prespecified control interventions were sham intra-articular corticosteroid and no intervention.

\section{Types of outcome measures}

In the previous review version there were eight outcomes: pain, physical function, patient global assessment, joint imaging, adverse reaction caused by procedure, adverse reaction caused by corticosteroid, adverse reaction caused by toxicity-related withdrawals, total number of withdrawals and dropouts. In the review update, there were two prespecified primary outcomes and six prespecified secondary outcomes. Primary outcomes were pain and physical function, and secondary outcomes were quality of life, joint imaging, and the number of participants who experienced any adverse event, withdrew because of adverse events, and experienced any serious adverse events.

\section{Search methods for identification of studies}

In the previous review version, the following four databases were searched: Cochrane Central Register of Controlled Trials (CENTRAL), MEDLINE (including PreMEDLINE), EMBASE, and Current Contents. The electronic searches were supplemented by handsearches of bibliographic references and abstracts published in conference proceedings or in special issues of specialised journals, and industry representatives were contacted to request additional studies of their product that could meet eligibility criteria. In the present review update, we searched the following three databases: Cochrane Central Register of Controlled Trials (CENTRAL), MEDLINE Ovid and PubMed platforms, and EMBASE. The electronic searches were supplemented by handsearches of bibliographic references, abstracts published in conference proceedings, and search of clinical trial registers to identify ongoing or recently concluded trials. 


\section{INDEX TERMS}

\section{Medical Subject Headings (MeSH)}

Adrenal Cortex Hormones [ ${ }^{*}$ administration $\&$ dosage; adverse effects]; Hyaluronic Acid [adverse effects; analogs \& derivatives; therapeutic use]; Injections, Intra-Articular; Osteoarthritis, Knee [*drug therapy; therapy]; Randomized Controlled Trials as Topic; Therapeutic Irrigation [methods]

\section{MeSH check words}

Humans 